\title{
Report on the Archaeological Investigations Conducted Between 1992 and 1993 at the Alamo Sales Museum (41BX6) Bexar
}

\section{County, Texas}

Steve A. Tomka

Raba Kistner

Anne A. Fox

Antonia L. Figueroa

Center for Archeological Research, University of Texas at San Antonio

Jennifer L. Thompson

Follow this and additional works at: https://scholarworks.sfasu.edu/ita

Part of the American Material Culture Commons, Archaeological Anthropology Commons, Environmental Studies Commons, Other American Studies Commons, Other Arts and Humanities Commons, Other History of Art, Architecture, and Archaeology Commons, and the United States History Commons

Tell us how this article helped you.

This Article is brought to you for free and open access by the Center for Regional Heritage Research at SFA ScholarWorks. It has been accepted for inclusion in Index of Texas Archaeology: Open Access Gray Literature from the Lone Star State by an authorized editor of SFA ScholarWorks. For more information, please contact cdsscholarworks@sfasu.edu. 
Report on the Archaeological Investigations Conducted Between 1992 and 1993 at the Alamo Sales Museum (41BX6) Bexar County, Texas

\section{Creative Commons License}

(c) (1) (8)

This work is licensed under a Creative Commons Attribution-NonCommercial 4.0 International License 


\title{
Report on the Archaeological Investigations Conducted Between 1992 and 1993 at the Alamo Sales Museum (41BX6), Bexar County, Texas
}

\author{
by \\ Steve A. Tomka, Anne A. Fox, \\ Antonia L. Figueroa and Jennifer L. Thompson \\ with contributions by
}

Barbara A. Meissner and Bruce K. Moses

Texas Antiquities Permit\# 1033

issued to Alton K. Briggs

Prepared for

THE DAUGHTERS OF THE REPUBLIC OF TEXAS

Prepared by:

Center for Archaeological Research

The University of Texas at San Antonio

Archaeological Report No. 388

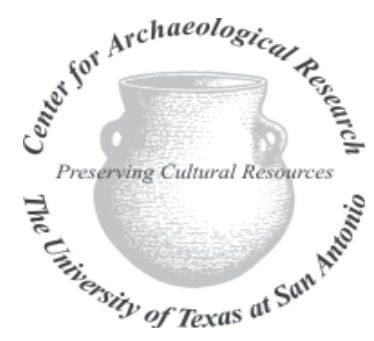





\begin{abstract}
:
Lone Star Archaeological Services, under the direction of Alton K. Briggs, conducted archaeological investigations in the vicinity and under the Sales Museum preceding the Sales Museum expansion project. The work was carried out between July 1991 and April 1993 under Texas Antiquities Committee permit number 1033 with Briggs serving as the Principal Investigator. Following the completion of the fieldwork, Briggs submitted several draft reports in order to fulfill permit requirements. The Texas Historical Commission rejected the draft reports and the permit lapsed into default. In 2003, the Center for Archaeological Research acquired the collection of artifacts recovered during the project and a fraction of the notes generated by the project. This report summarizes the results of the analysis conducted on the collection and describes the excavation results as they can be reconstructed based on the information available to the CAR staff. All artifacts collected during this project and all projectassociated documentation is permanently curated at the Center for Archaeological Research according to Texas Historical Commission guidelines.
\end{abstract}




\section{Table of Contents:}

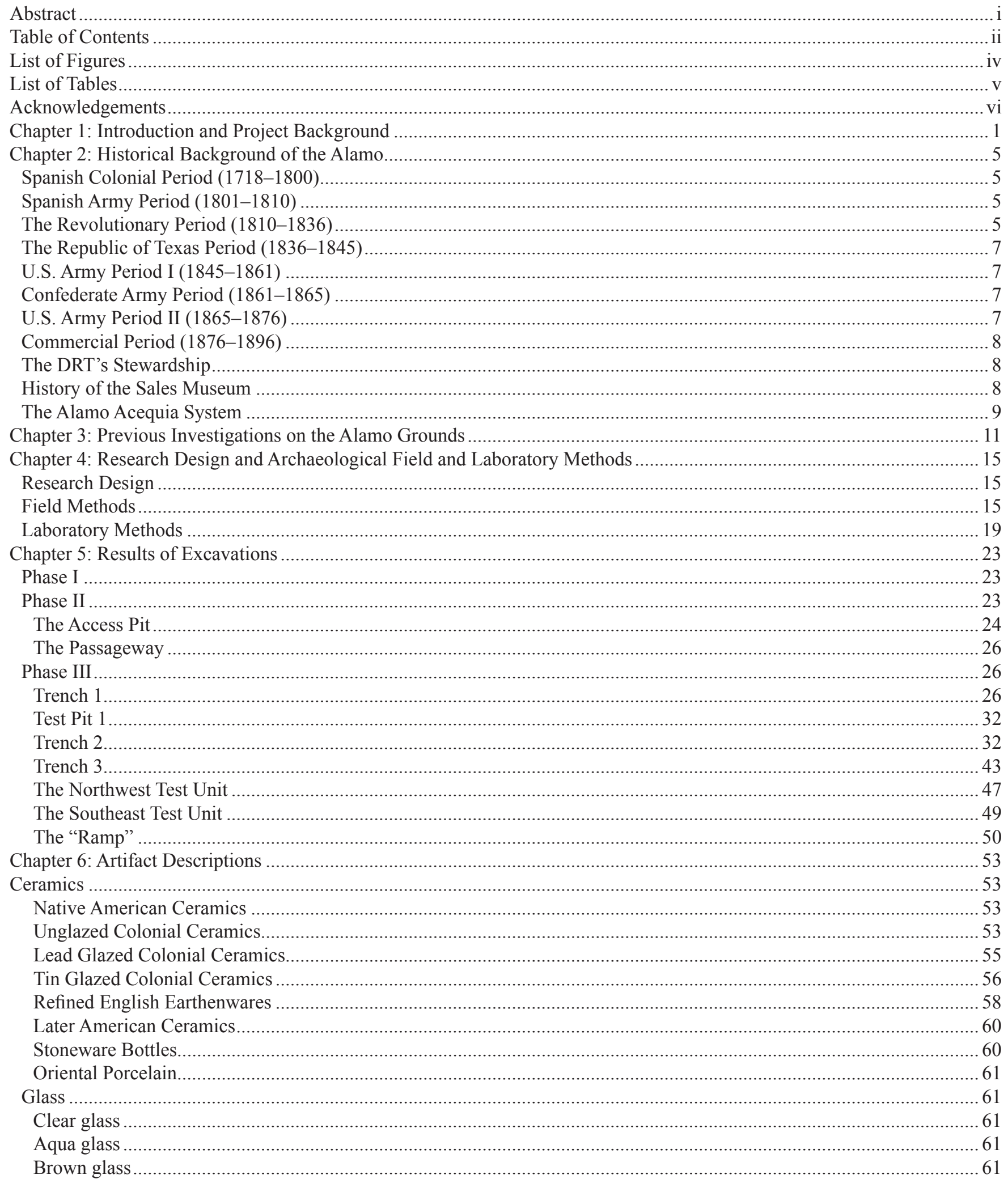


Cobalt glass 61

Amber glass. 61

Bright green glass 61

Milk glass 61

Metal Objects 61

Horse Equipment. 62

Household Objects 62

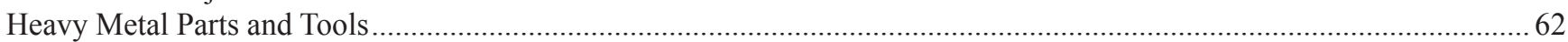

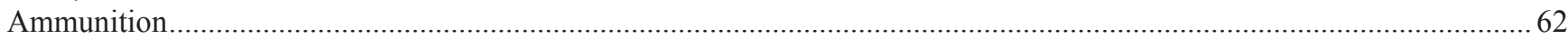

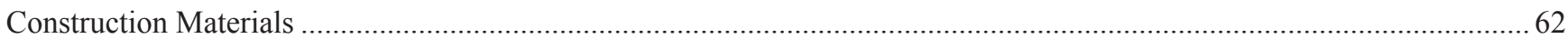



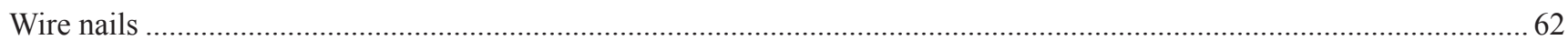

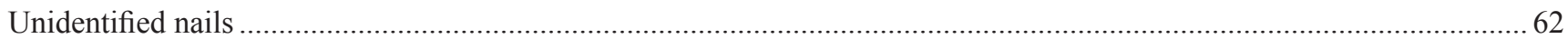

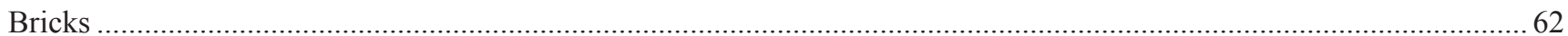

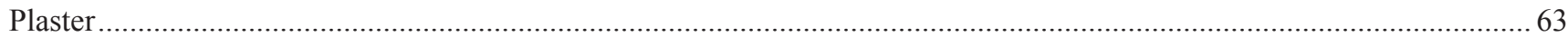

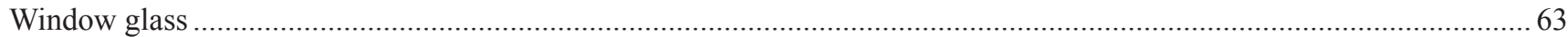

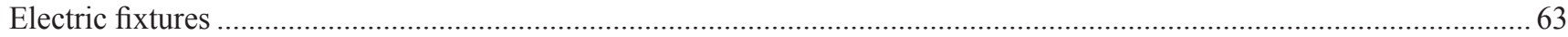

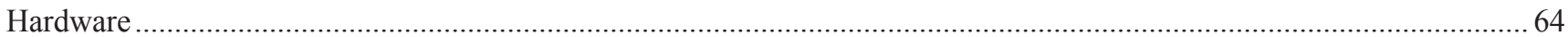

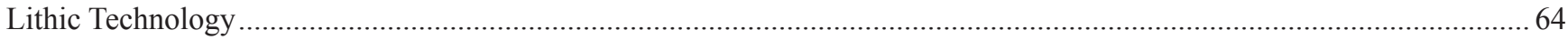

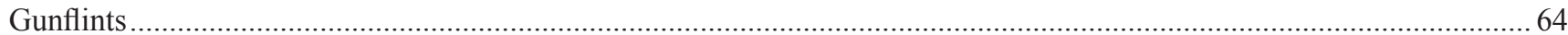

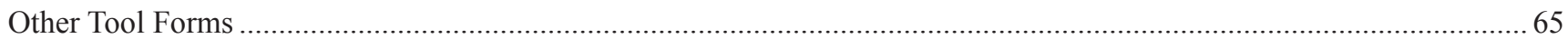

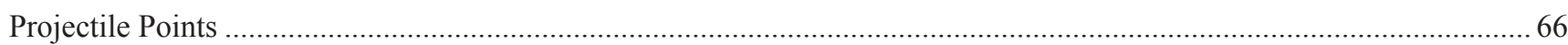

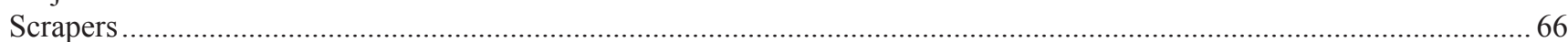

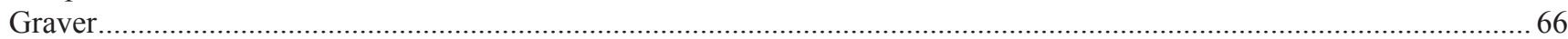

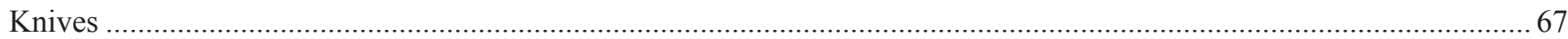

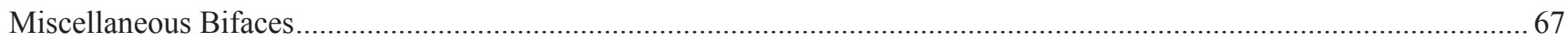

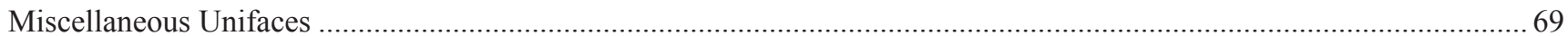



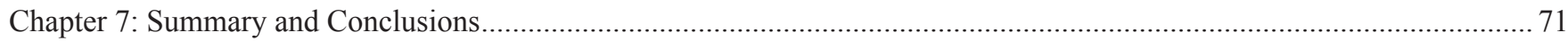

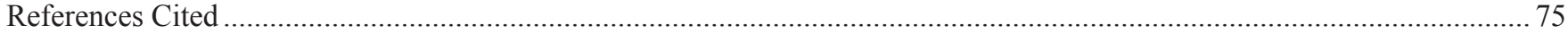




\section{List of Figures:}

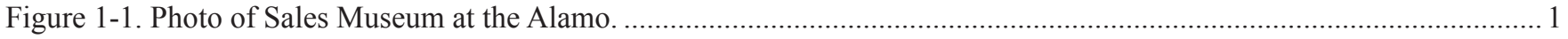

Figure 1-2. Map showing the construction perimeter around the Sales Museum. ..................................................................2

Figure 2-1. Locations of acequias in the vicinity of the Alamo Complex as shown on the

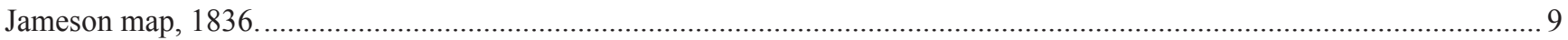

Figure 2-2. Diversion in the acequia route in the vicinity of the Sales Museum............................................................ 10

Figure 3-1. Previous archaeological investigations conducted at the Alamo. .................................................................. 12

Figure 4-1. Location of units excavated by Lone Star Archeological Services under and in the

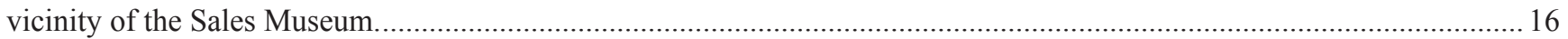

Figure 4-2. Detail of units associated with the Access Pit at north end of Sales Museum................................................. 18

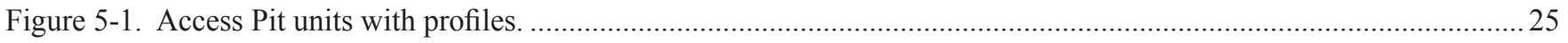

Figure 5-2. Profile of North Wall of Trench 1 and South Wall of extension under building. ............................................ 29

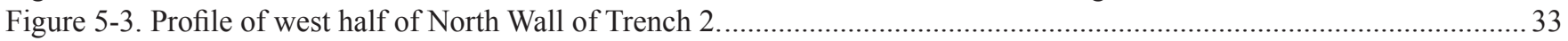

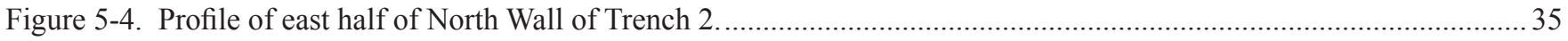

Figure 5-5. Profile of North Wall of East-West extension of Trench 2 …........................................................................ 36

Figure 5-6. Profile of North Wall of Trench 3 and West Wall of extension under building. ..................................................... 44

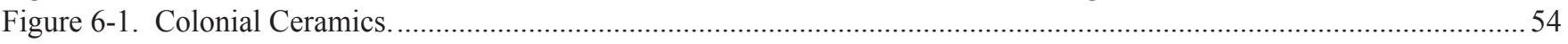

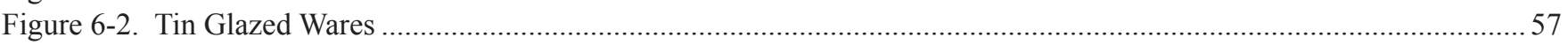

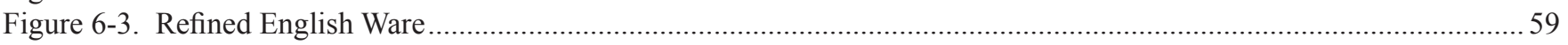

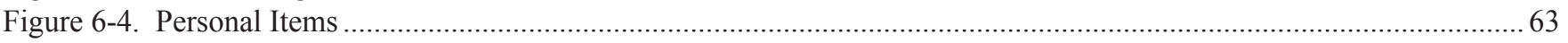

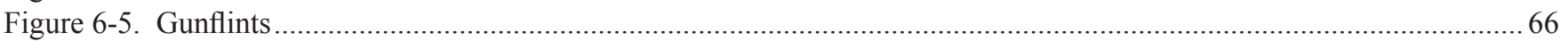

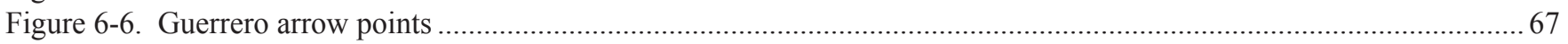




\section{List of Tables:}

Table 5-1. Artifacts Recovered from 50-x-50 cm Test Units Excavated Under the Sales Museum .......................................2 24

Table 5-2. Proveniences from Access Pit Excavations and Analysis Units Defined by CAR ..............................................26

Table 5-3. Artifacts Recovered from the North Access Pit by Analysis Unit ....................................................................2

Table 5-4. Breakdown of North Access Pit Artifacts by Temporal Affiliation ……….......................................................2.

Table 5-5. Proveniences from Trench 1 Excavations and Analysis Units Defined by CAR ...................................................30

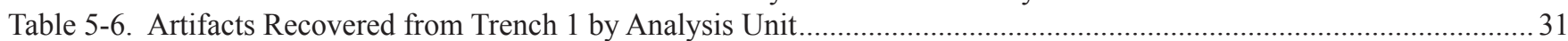

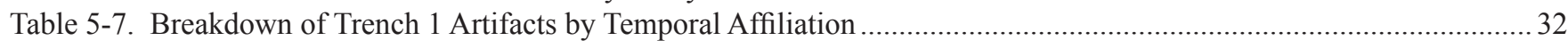

Table 5-8. Proveniences from Western Half of Trench 2 Excavations and Analysis Units Defined by

CAR . .37

Table 5-9. Artifacts Recovered from the Western Half of Trench 2 by Analysis Unit .........................................................38

Table 5-10. Breakdown of Artifacts from Western Half of Trench 2 by Temporal Affiliation ..............................................39

Table 5-11. Proveniences from Eastern Half of Trench 2 Excavations and Analysis Units Defined by

CAR

Table 5-12. Artifacts Recovered from the Eastern Half of Trench 2 by Analysis Unit .

Table 5-13. Breakdown of Artifacts from Eastern Half of Trench 2 by Temporal Affiliation

Table 5-14. Proveniences from East-West Extension of Trench 2 Excavations and Analysis Units

Defined by CAR

Table 5-15. Artifacts Recovered from the East-West Extension of Trench 2 by Analysis Unit ............................................ 42

Table 5-16. Breakdown of Artifacts from East-West Extension of Trench 2 by Temporal Affiliation.................................... 43

Table 5-17. Proveniences from Trench 3 Excavations and Analysis Units Defined by CAR ..................................................45

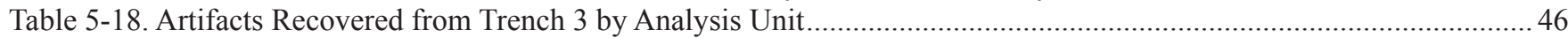

Table 5-19. Breakdown of Artifacts from Trench 3 by Temporal Affiliation ...................................................................4

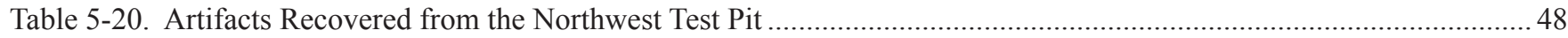

Table 5-21. Breakdown of Artifacts from Northwest Test Pit by Temporal Affiliation........................................................ 49

Table 5-22. Proveniences from the Southeast Test Pit and Analysis Units Defined by CAR................................................50

Table 5-23. Artifacts Recovered from Southeast Test Pit ...............................................................................................51

Table 5-24. Breakdown of Artifacts from Southeast Test Pit by Temporal Affiliation........................................................52

Table 5-25. Proveniences from Ramp Excavations and Analysis Units Defined by CAR ...................................................55

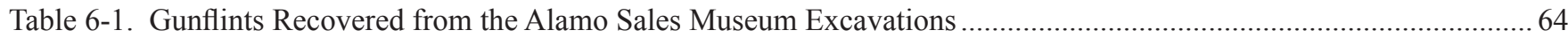

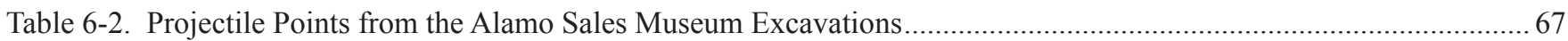

Table 6-3. Lithic Tools and Miscellaneous Bifaces and Unifaces from the Alamo Sales Museum

Excavations 


\section{Acknowledgements:}

The authors would like to thank David Stewart, Director of the Alamo, and Dr. Bruce Winders Curator of the Alamo for making this report possible. The project could not have been possible without their gracious answers to the multitude of questions we had and their patience with the slow pace of progress. We would also like to thank the elegant, and always willing to help, Laura Beavers, a Daughter of the Republic of Texas, for her continued help in keeping communication flowing between CAR and the staff of the Alamo. We also acknowledge the help and encouragement of Mark H. Denton of the Texas Historical Commission who had the institutional memory and foresight to remember and push for the completion of the technical report on the Sales Museum work. Miss Elizabeth Martindale, of the Texas Historical Commission, also was helpful in providing some details on the original project Scope of Work on file at the agency. Finally, we would like to acknowledge Mr. Alton K. Briggs, who although no longer involved with the project, answered several emails from us requesting details about this project. Although no fieldwork on the part of the CAR staff was involved in this project, many individuals helped with the completion of the project. Kristi Ulrich and Marybeth S.F. Tomka, laboratory coordinator, combined on the processing of the collection. Bryant Saner completed the flotation of the soil samples. Rick Young and Bruce Moses completed the scans of the artifacts and the production of the figures. Bruce also served as Technical Editor for this report. 


\section{Chapter 1: Introduction and Project Background}

In the early 1990s the Daughters of the Republic of Texas, in the person of Marjorie M. Hardy, Alamo Committee Chairman, approved the Alamo Sales Museum Expansion Project at the Alamo Shrine and Museum (Mission San Antonio de Valero) located in San Antonio, Bexar County, Texas (Figure 1-1). Mission San Antonio de Valero (41BX6) is a State Archeological Landmark and is listed on the National Register of Historic Places. The remodeling and construction activities associated with the expansion project were to be carried out by Robert Morris Architectural Associates, Incorporated of San Antonio.

The remodeling project had two principal goals: 1) create office and storage space under the existing Alamo Sales Museum building; and 2) create elevator access to this below-ground floor. The construction-related impacts to the Alamo Sales
Museum building and its vicinity involved the excavation of the matrix from under the building and the construction of an elevator shaft north of the building connected to the ground floor by a hallway. Subsurface impacts were to extend only to about 3-feet from the base of the western wall of the Sales Museum (Figure 1-2). Along the east wall and south of the second pier, excavation impacts were to extend to a distance of approximately 15 -feet from the base of the wall, to the immediate edge of the acequia. North of the second pier, the subsurface impacts were to reach almost 30-feet east of the base of the wall. Only the southeastern corner of the Sales Museum was to see impact on the south side of the building. Here, excavations were to extend to about 3-feet from the base of the wall. Finally, significant subsurface impacts were to occur north of the building extending under the sidewalk along East Houston Street. This area was to house the elevator shaft and the long tunnel connecting the elevator to the main

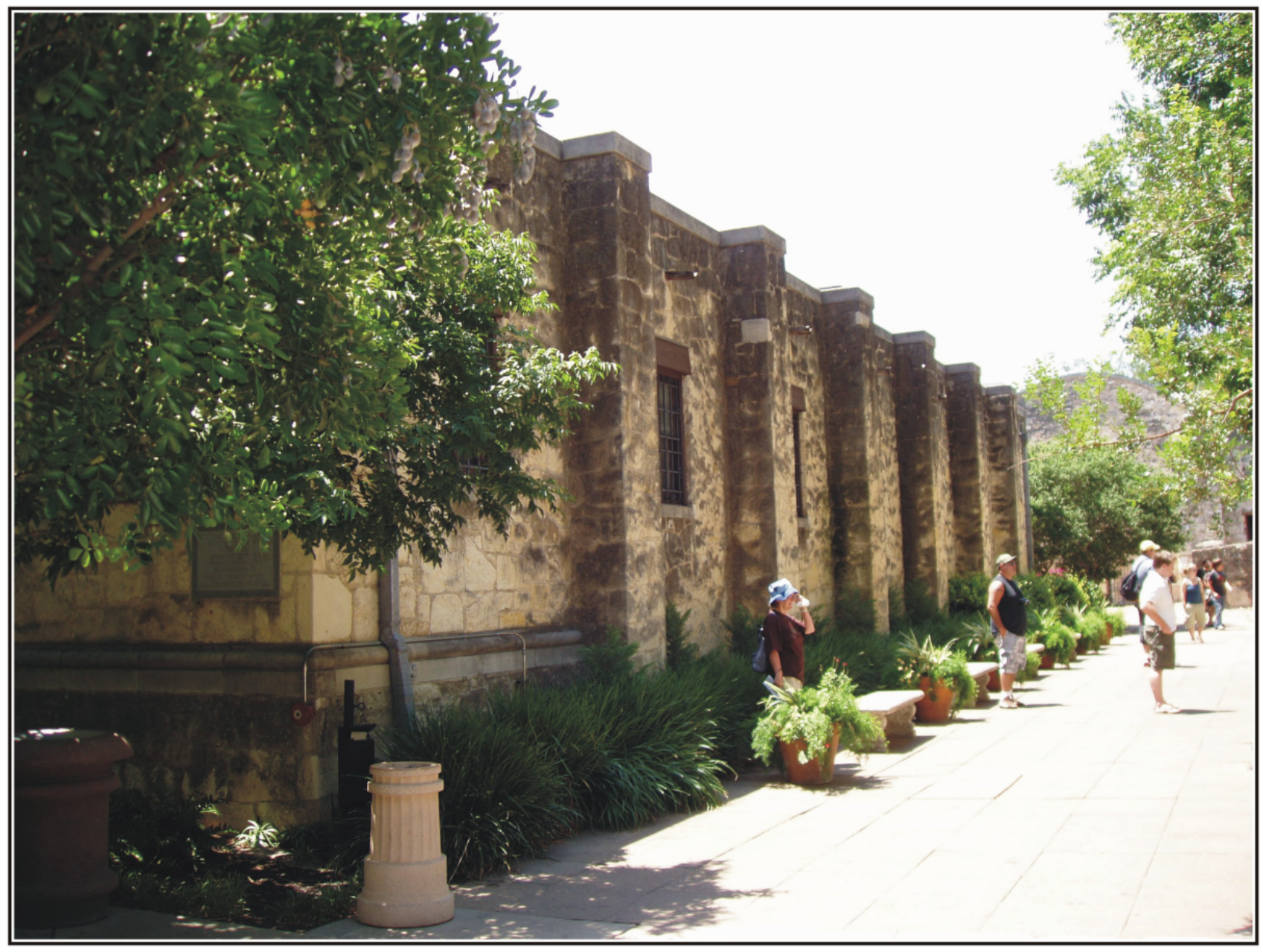

Figure 1-1. Photo of Sales Museum at the Alamo. 


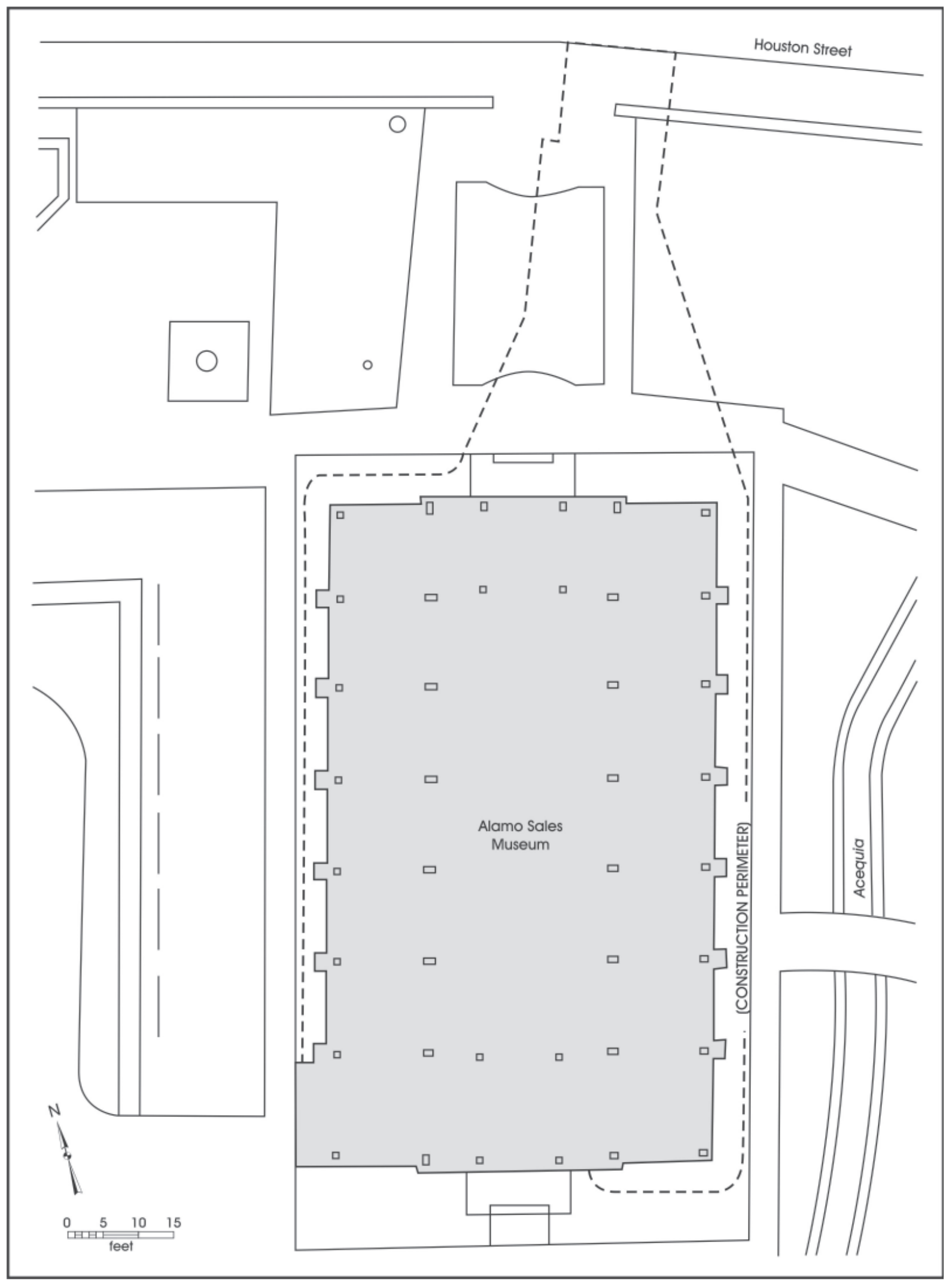

Figure 1-2. Map showing the construction perimeter around the Sales Museum. 
portion of the below-ground office spaces planned under the Sales Museum. These excavations were to take place under the small patio-like rest area north of the north entrance to the Sales Museum (Figure 1-2). In addition, to provide for proper drainage, a French drain system was to be installed along the western and eastern walls of the Sales Musem.

Complicating the construction plans was the identification of asbestos particles flaked off of heating ducts and steam pipes under the Alamo Sales Museum (ASM). The asbestos had to be removed and the area made safe prior to any archaeological investigations under the structure.

Between July 1991 and April 1993, Lone Star Archeological Services (LSAS), under the direction of Alton R. Briggs, conducted archaeological investigations associated with this planned remodeling. The archaeological services provided by LSAS consisted of: 1) pre-asbestos abatement testing; 2) asbestos abatement monitoring; 3) machine trenching of project area; 4) impact area testing prior to the excavation of the basement; and 5) monitoring of basement and tunnel excavations and recovery of selected artifacts. All of the work was carried out under Texas Antiquities Permit Number 1033, with Alton K. Briggs serving as Principal Investigator.

Briggs prepared at least three reports on the results of the Alamo Sales Museum investigations (Briggs 1992, 1993, 1998). The first report (Briggs 1992), apparently intended to serve as an interim report, was submitted in the fall of 1992. A subsequent draft report was submitted in 1993 and the final report (Briggs 1998) was submitted in January 1998. The Texas Historical Commission reviewers of the report found it to be unacceptable in satisfying permit requirements and requested major revisions and a new draft. This revised draft was never produced and in the meantime the artifacts came to be stored in the basement of the Sales Museum for several years.

In the fall of 2003, Mark Denton of the Texas Historical Commission's Archeology Division brought the old project and the large collection of artifacts recovered during the Briggs excavations to the attention of staff of the Center for Archaeological Research. After inspecting the storage unit housing the collections at the Alamo, the Center agreed to more thoroughly inspect and assess the collection's research potential and provide a cost estimate encompassing: (1) the analysis of the collections; (2) their preparation for curation; (3) the production of a technical report to satisfy permit requirements; and (4) shelf fees to curate the collection at the Center's curation facility.

Early in 2003, 45 boxes of materials consisting of 36 boxes of artifacts and 9 boxes of soil samples were relocated to the UTSA campus where the staff spent several weeks assessing the condition of the collections, the accuracy of the catalogue produced by Briggs, and the research potential of the materials. In May 2004, a cost estimate was provided to Mr. David Steward, Director of the Alamo while the collection continued to be temporarily stored at the Center. In June 2004, the Alamo Committee under the direction of Ms. Mary Walker, President General of the DRT, accepted the CAR proposal and contracted the Center to carry out the proposed work.

Work began on the collections and report under the direction of A.A. Fox and continued until 2006, when Fox retired from the Center. Unfortunately, little progress was made on the partially completed manuscript until the late fall of 2007 due to other staff commitments. The draft report was subsequently completed and submitted for the Sponsor and Texas Historical Commission reviews.

This report is the product of a lengthy collaboration between the Alamo Committee and staff of the Center for Archaeological Research. The report is organized in eight chapters. Chapter 1 consists of the introduction and provides a brief background to the project. Chapter 2 provides a detailed historical background of the Alamo with a section dedicated to the history of the Sales Museum and its vicinity. Chapter 3 consists of a brief summary of the previous excavations carried out on the Alamo grounds. Chapter 4 reconstructs, based on field notes and information provided in the interim and rejected final report, the research design that guided the field investigations of the ASM. It also reviews the archaeological field methods employed during the investigations and laboratory methods used to process the artifacts following the fieldwork and once at the CAR laboratory. Chapter 5 consists of a detailed summary of the results of the investigations while Chapter 6 contains the artifact descriptions. The final chapter, Chapter 7 , provides a summary of the investigations and principal conclusions. 



\title{
Chapter 2: Historical Background of the Alamo
}

\author{
Barbara A. Meissner, Anne A. Fox, and Bruce K. Moses
}

In 1709 under the command of Pedro de Aguirre, Fray Antonio de San Buenaventura y Olivares, serving as the chaplain and Father Isidro Felix de Espinosa, serving as diarist, headed north of the Rio Grande River to make contact with Tejas Indians to determine whether they could serve as a buffer against the French who were rumored to be interests in territories considered under Spanish dominion (Chipman 1992:107-110). The expedition reached as far as the Colorado River but not before making a stop in the vicinity of San Pedro Springs in modern-day Bexar County. The well watered and productive land impressed Olivares so much that when in 1718 he and commander Martín de Alarcón were charged with relocating Mission San Francisco Solano north of the Rio Grande to serve as a way station between the Rio Grande and the East Texas missions, Olivares stopped on the banks of the San Antonio where he was awarded official possession of Mission San Antonio de Valero. The new mission represented a transfer of neophites from the Rio Grande (Chipman 1992:117).

\section{Spanish Colonial Period (1718-1800)}

The establishment of Mission San Antonio de Valero on May 1, 1718 represents the beginning of permanent occupation of what later becomes San Antonio (de la Teja 1995:8; John 1975:206-207). Here, Olivares believed, the land could easily support a large mission. The location, at the border between what is now southwest Texas and northern Mexico, was highly strategic. A mission, presidio, and civilian community established at the head of the San Antonio River would provide a secure way station between the Rio Grande and the East Texas missions (Habig 1968:38).

The mission was located on high ground along San Pedro Creek, almost two miles south of the springs (Habig 1968:38). Four days later, the Presidio San Antonio de Béxar and the civilian community of Villa San Fernando de Béxar were established near San Pedro Springs.

Sometime during 1719, the mission site was moved to the east side of the San Antonio River, to what was seen as a better location and in 1722 the presidio was moved to a site just across the river on the west side (Habig 1968:42). The new mission site was south of the present location, near where Commerce Street crosses the river today (Cox 1994:1). However, in 1724 a hurricane devastated the mission compound, so it was moved north to its present location and the presidio was moved to a site just across the river on the west side (Habig 1968:44).

Between 1727 and 1762, the Native American population of the mission, averaging a little more than 270 , had remained more or less stable except for the year 1739 when a plague of small pox and measles devastated all the missions (Casteñeda 1938:71). But after 1762, the population was much lower than in previous years, averaging only about 80. However successful the mission effort had been at the beginning (Casteñeda 1938), it was clearly in decline by the late-eighteenth century. In 1793, a royal decree secularized Mission San Antonio de Valero, and the mission lands were divided among the 15 remaining mission Native Americans and 54 local Spanish citizens (de la Teja 1995:86). The mission records were turned over to the San Fernando parish (Habig 1968:70).

\section{Spanish Army Period (1801-1810)}

In 1801, the Segunda Compania Volante de San Carlos de Parras del Alamo (the Second Flying Company of San Carlos of Parras of the Alamo) was assigned to enhance the Presidio de Béxar. They established themselves in the old mission buildings at San Antonio de Valero and erected barracks, some inside old buildings (Fox et al. 1976:6-7). It was the name "del Alamo," celebrating the little town near Parras, Mexico, where the company had been recruited, that became the name of the garrison and the little pueblo in and around the old mission compound (Habig 1968:71). In 1806, the Spanish army established a hospital in the old convento building, and eventually a doctor and a dentist were available (Schuetz 1966:34-35). In 1808 a two-room pharmacy was built inside the unfinished church (Almaráz 1971:85).

\section{The Revolutionary Period (1810-1836)}

On September 16, 1810, Father Hidalgo, claiming the Spanish government was about to turn Mexico over to the French, declared revolution. During the next months, rebellion was fomented all over the northern part of Mexico. Governor Salcedo arrested agents in Villa San Fernando (San Antonio), his own capital, who were delivering revolutionary propaganda (Garrett 1968[1939]:35). On the evening of January 21, 1811, in the barracks along the south wall of the former Mission San Antonio de Valero, final plans for a mutiny were completed (Garrett 1968[1939]: 44). The next 
morning, rebels captured Salcedo and several other officials and loyal officers. The town was retaken by men at least nominally loyal to the Spanish government on March 2, 1811 (Almaráz 1971:121).

Salcedo set out to destroy the rebellion, capturing and executing Father Hidalgo and virtually all the major leaders of the rebellion (Garrett 1968[1939]:72). José Bernardo Gutiérrez de Lara became the rebellion's next leader (Garrett 1968[1939]:83). In August 1812, with American adventurer Augustus Magee, Gutiérrez invaded Texas with the self-styled Republican Army of the North, composed largely of American volunteers (Garrett 1968[1939]:151). In March 1813, after losing a battle to the invading army not far from San Antonio, Salcedo surrendered the city. Salcedo and about 13 other officers were taken out of San Antonio, under pretext of sending them to Matamoros, and murdered (Almaráz 1971:171). This action disgusted many of the Anglos and some 100 returned immediately to the United States (Filisola 1985[1848]:21). On April 6, 1813, a declaration of independence from Spain was signed. However, in August 1813, José Joaquín Arredondo, sent to end the rebellion, destroyed the republican army outside San Antonio. The inhabitants of the city were brutally treated by Spanish soldiers, surrounded by hostile Native Americans, and nearly starved during the winter of 1814 (Menchaca 1937:19). Another revolution, in which Texas was only peripherally involved, finally ended Spanish sovereignty in Mexico in 1821. Within a few years, conditions in San Antonio improved considerably (Menchaca 1937:20.

The incidents leading to the battle which is the most famous event at the Alamo are well known, although some details are still somewhat controversial. A detailed discussion of these events is not included in this report. The reader is referred to Barr (1990), de la Peña (1975), Hardin (1994), and Winders (2004) for a more complete examination of the Texan Revolution.

In 1835, General Martín Perfecto de Cós, was sent to San Antonio to regain control of Texas. He began by fortifying the old garrison at the Alamo. He knocked down the arches of the unfinished church ceiling and used them as part of the fill needed to build a ramp sloping from the front door to the top of the back wall (letter from S. A. Maverick to S. M. Howe, July 3, 1847, in Young 1991:32). At the back wall, scaffolding was built to hold cannon and men behind the relative safety of the stone walls (Cox 1994:6). The walls of the old mission compound, now largely in ruin, were rebuilt to the extent possible, and a wooden palisade and ditch were built from remaining buildings on the south wall to the southwest corner of the church, completing the enclosure (Cox 1994:6).

The Texans decided their next step was to retake San Antonio. As the "Army of the People" approached, Cós pulled his troops into town and the Alamo and resolved to wait them out.

After a month of waiting, Colonel Ben Milam demanded "who will follow Old Ben Milam into San Antonio?" (Fehrenbach 1968:197). This highly dramatic scene restored the Texans' enthusiasm, and some 300 men followed Milam into the town early on the morning of December 5. After a three-day, house-to-house battle, the Texans captured the town. On December 10, Cós surrendered his garrison at the Alamo and, after signing a parole promising never again to fight against the colonists or to defy the Constitution of 1824 , was allowed to leave with his troops.

By January 1836, the political chaos in Texas had reached an untenable level. Santa Anna would be coming, and he would come first to San Antonio. The Alamo was the obvious place to form a defense, but the Texans needed many more men than were available. James Bowie insisted that they could not afford to let the Mexican army have San Antonio, as it was the last stronghold between Santa Anna and the Sabine River (Fehrenbach 1968:205). When the decision to hold the Alamo was made, no one had any idea how quickly Santa Anna was coming, but on February 23, the Mexican army arrived. Thirteen days later, on the morning of March 6, 1836, the Alamo fell and all defenders were killed.

In the past, destruction of rebel forces in San Antonio rapidly led to an ending of open rebellion in Texas, and Santa Anna probably thought the same would happen again. He failed to realize that the center of this rebellion was not in San Antonio, and that the men he fought were not the peasants he was accustomed to fighting. Instead, he faced men with a tradition of successfully fighting for freedom and with expectations of help from the United States. Sam Houston's strategy of falling away before the Mexican army must have convinced Santa Anna that he was succeeding in sweeping the foreigners out of Texas.

However, On April 21 at San Jacinto, Santa Anna was caught by surprise by the Texan army. The battle was short and bloody. Still angry about the Mexican army's treatment of prisoners at the Alamo and Goliad, the Texans captured Santa Anna and slaughtered large numbers of Mexican soldiers as they tried to surrender. To earn his release, Santa Anna signed a treaty agreeing to pull all Mexican soldiers south of the Rio Grande, and never again to fight against Texas (Fehrenbach 
1968:241). Texas was now an independent nation (Fehrenbach 1968:246).

When Santa Anna left San Antonio, Colonel José Andrade and about 1,000 Mexican soldiers were left behind to control the city. After the battle at San Jacinto, Andrade was ordered to depart, after rendering the Alamo useless as a fortress. Andrade spiked the cannons, tore down single walls, and set fire to the scaffolding inside the church (Cox 1994:7). When he and his soldiers marched out of San Antonio, the Alamo was in ruins.

\section{The Republic of Texas Period (1836-1845)}

The people of San Antonio had endured 25 years of rebellion and retaliation. Several times the town and its garrison at the old mission had been taken and punished by rebels, and several times it had been retaken by government soldiers. The citizens of San Antonio now found themselves citizens of the Republic of Texas. Between 1836 and 1845, Texas was an independent nation. For San Antonio, these were not quiet years. The Native American groups living nearby had become even more aggressive than before (Jenkins 1973:5694), and Mexico, after a few years of ignoring Texas, began to regularly raid across the Rio Grande.

Soon after the ill-fated Santa Fe expedition, General Santa Anna, now back in power, ordered General Rafael Vásquez and 700 men to raid and sack the town of San Antonio (Anderson 2005:197, Jenkins 1973:95). A number of Anglo Texans were captured during this brief nuisance raid and taken back as prisoners to Mexico (Paulus 1939:62). In September, a force of fourteen hundred troops under the direction of Mexican General Adrian Woll wrecked havoc across South Texas and captured and held San Antonio for almost a week (Anderson 2005:197). This military incursion climaxed with the Battle of Salado Creek which resulted in the hasty withdraw of Mexican forces (Handbook of Texas Online, 2008). In October 1845, the U.S. Army set up camp in San Antonio, responding to President Polk's order to secure the Texas border until the question of the United States' annexation of Texas could be settled (Cox 1994:12).

\section{U.S. Army Period I (1845-1861)}

On April 23, 1846, Mexico declared war on the United States. The next day Mexican troops crossed the Rio Grande with the intention of eventually retaking all of Texas (Faulk and Stout 1973:1). During the two years of war which followed, San Antonio served as the staging area for all U.S. Army operations in Mexico and the Southwest (Cox 1994:12).
By the end of the war with Mexico, the need for a permanent military presence in San Antonio had become clear. In 1847, the U.S. Army leased the Alamo church and convento from the Catholic church and soon began making repairs to the Long Barrack for use as a quartermaster and commissary depot (Cox 1994:12 ). The army also roofed the church and built a number of small outbuildings in the convento patio between 1848 and 1850 .

In January 1850, the city council of San Antonio decided the city was the legal owner of the buildings, and sued the Catholic Church to gain title. The issue went all the way to the Supreme Court of Texas, which ruled in favor of the church in 1853 (Story 1938:39).The matter of ownership having been settled, the Quartermaster Corps finished construction of the depot. The presence of the army depot increased traffic around Alamo Plaza enormously. The increased activity attracted other businesses. The Menger Hotel, just south of the Alamo, was completed in 1859 and several saloons opened nearby.

A brewery, meat market, and the bustling activity around the Quartermaster's depot made Alamo Plaza one of the centers of commerce in San Antonio (Cox 1994:16). However, the relative peace of San Antonio after 1846 was about to be shattered again. Tension between the North and South had become intolerable. The news of Lincoln's election late in 1860 was, for the South, a signal for rebellion.

\section{Confederate Army Period (1861-1865)}

In late January 1861, an election was held in San Antonio for delegates to a state convention which would consider secession from the United States (Darrow 1884-1887:33).On February 1, 1861, the Texas Secession Convention passed an Ordinance of Secession (Fehrenbach 1968:344). On February 16 a force of about 1,000 confederate sympathizers infiltrated the town (Bowden 1986:51; Darrow 1884-1887:34) and took possession of the arsenal and the Alamo and demanded that the army surrender and deliver all federal property to them. More than a month after the surrender of Lee at Appomattox, the last pitched battle of the Civil War took place near Brownsville (Fehrenbach 1968:389-391). There was never a formal surrender in Texas, but the Confederacy-both military and Civilian-simply faded away.

\section{U.S. Army Period II (1865-1876)}

In post-war years Alamo Plaza became more important to the city. In June of 1871, the Catholic Church decided to sell all its remaining property in Alamo Plaza, except the land on 
which the Alamo church itself stood. The area surrounding the "Galera" building (formerly known as the Low or South Barracks) was sold to the City of San Antonio for $\$ 2,500$ with the stipulation that the land should be dedicated to public use (San Antonio Light, 1905). Much of the remaining property, including the Long Barrack, was sold to Honoré Grenet. The church building was also leased to Grenet for 99 years (Story 1938:47-48).

\section{Commercial Period (1876-1896)}

Grenet renovated the convento to make the building look like a fortress when viewed from Alamo Plaza. The patio behind the convento was used as a wagon yard, and the buildings constructed around the patio by the army were used as storage sheds. The Alamo church was also repaired, and became a warehouse for his store (Story 1938:49).

Eventually, in 1883, the Texas legislature decided that the Alamo chapel should be purchased by the state. On May 12, 1883, the Catholic Church transferred title to the state for the price of \$20,000 (Bexar County Deed Records [BCDR], Bexar County Courthouse, San Antonio, Texas, 31:265-267). The city of San Antonio agreed to assume upkeep of the building (Story 1938:54).

Honoré Grenet died in 1882 and, in 1885, his heirs sold the property to Charles Hugo, Gustav Schmeltzer, and William Heuerman, also retail and wholesale grocers. The Alamo church, now state property in the custody of the city, was a tourist attraction. For several years after the city of San Antonio took possession of the Alamo chapel, it was used for storage. A custodian was hired and a few minor repairs made, but in general the city resisted the request of many public-spirited citizens to do more (San Antonio Daily Express [SADE], 3 February 1896). When asked where the money needed to implement these recommendations was to be found, the chairman of the committee acknowledged the difficulty, but added, "it is a very costly patriotic thing, but I guess any other town in the State would be glad to have it" (SADE, 3 February 1896).

\section{The DRT's Stewardship}

The Daughters of the Republic of Texas had been officially organized on November 6, 1891. Membership in the DRT was limited to the female descendants of persons living in Texas before and/or during the revolution that freed the state from Mexico (Story 1938:61). Their stated purpose was to preserve the heritage of the state, and to arouse in all Texans a sense of duty toward the preservation of historic landmarks and documents (Story 1938:61). One of the major goals of this quickly growing organization was to care for the Alamo (Story 1938:62).

By 1904 continuing commercial development of Alamo Plaza made the property on which the convento sat very valuable. It was, in fact, about to be sold to an out-of-state syndicate wishing to build a hotel, taking advantage of the historic significance of the site. Many in San Antonio believed that such development on Alamo Plaza was for the good of the city (Story 1938:63). However, in February 1904, the convento property was sold to Clara Driscoll, with the following condition:

It is distinctly understood and agreed that this property is purchased by Clara Driscoll for the use and benefit of the Daughters of the Republic of Texas, and is to be used by them for the purpose of making a park about the Alamo, and for no other purpose whatever [BCDR 223:261].

Within the DRT one faction wanted to clear the old convento grounds and make a park, with appropriate monuments. Another wanted to restore the convento grounds to a condition similar to that of 1836 (Story 1938:83). In 1908 the lease with Hugo and Schmeltzer expired, and attorneys for both sides in the DRT agreed to turn over the property to the state, temporarily, until the matter could be settled (Story 1938:88). It was a reunited DRT that now faced governor O. B. Colquitt, who had developed his own plan for restoring the Alamo and the convento (Story 1938:95-96). This plan included removing not only the wooden superstructure built by Grenet, but also the upper floor of the convento. He got $\$ 5,000$ dollars appropriated, and had workmen begin tearing down the wooden superstructure.

The DRT did not approve and, in February 1912, passed a resolution to resume trust of the Alamo (Story 1938:105). The governor refused to back down, the DRT filed an injunction, and during the next year, while control of the Alamo was decided in court, all work stopped (Story 1938:109-111). The Texas Supreme Court handed down a decision in June 1913 instructing the governor to spend the $\$ 5,000$ dollars on restoration of the Alamo buildings, but that once the money was spent, the DRT retained control (Story 1938:118).

The DRT resumed the restoration and, by Fiesta week in Apri1 1914, a great deal of work had been done to make a park, incorporating the governor's work (Story 1938:120). In 1926, the City of San Antonio continued the acquisition of land surrounding the Alamo by purchasing several 
commercial buildings immediately south of the church. During 1931 and 1932 the state also bought property around the Alamo, and in 1936 the United States government granted money for restorations and purchase of the remaining private property on the east side of Alamo Plaza between Houston and Crockett streets. The entire area was designated The Alamo State Park.

\section{History of the Sales Museum}

Architect Henry T. Phelps designed the park and a museum within it. The design was approved by the State Board of Control in 1936. The bid for construction of the Alamo Sales Museum and other work to be done within the park was received on February 3, 1937, and work was begun soon thereafter. During the 1937 renovations, a concrete replica of the old acequia, that ran east of the church was constructed above the original (Daughters of the Republic of Texas 1994:2). Construction was also begun on a perimeter stonewall around the property and on a museum to the north of the chapel.

In October of 1938 plans were under way for the dedication of the new Alamo State Park. The Alamo Committee of the Daughters of the Republic of Texas was sponsor of the celebration. The presentation of Mrs. Clara Driscoll, who had given funds to enlarge the site, was planned for the occasion.

The San Antonio Evening News (10-08-1938) publicized the occasion announcing that: on account of illness (The San Antonio Evening

News, 10-15, 1938).

\section{The Alamo Acequia System}

The mission was moved to the east side of the river in 1719 , and was in operation by February 1720. Due to the immediate need for production of crops, construction of an acequia to irrigate the surrounding land to the east was started as soon as possible. In 1723 a dam was built across the San Antonio River at what is now the north edge of Brackenridge Park and an acequia was completed ca. 1727 (Paredes 1727). The main acequia or Madre Ditch ran some distance to the east of the second mission to irrigate the fields in that area. A western branch extended slightly to the west past the east side of the present site of the mission and continued a league to the south, joining the Madre Ditch near the second site, then to eventually return to the San Antonio River farther south (Cox 2005:21).

In 1724 when a storm destroyed the second mission, it was moved ca. 1700 feet north to the present site. When the acequia was first constructed, a desague from the western branch had been dug through what would be the new location in order to drain excess water from the acequia into the river, as was customary. Figure 2-1, shows the locations of the acequias in the vicinity of the Complex as they appeared on a version of the Jameson 1836 map reproduced by Williams (1931) in her dissertation. Note that this map is a different version than the one commonly attributed to Jameson (see Nelson 1998:47). To allow for the layout of the new mission plan, it was

Prominent citizens of San Antonio and others from various sections of the state were to participate in a patriotic celebration dedicating the Alamo Museum and Park. Addresses, a musical program, placing of documents in sealed vaults, and presentation of prominent guests were to be part of the program, which was to concluded with a garden party.

The Alamo Park Museum opened on October 15, 1938, and more than 500 people attended the ceremony. Although she was in part responsible for this momentous occasion, Mrs. Clara Driscoll unfortunately was unable to attend

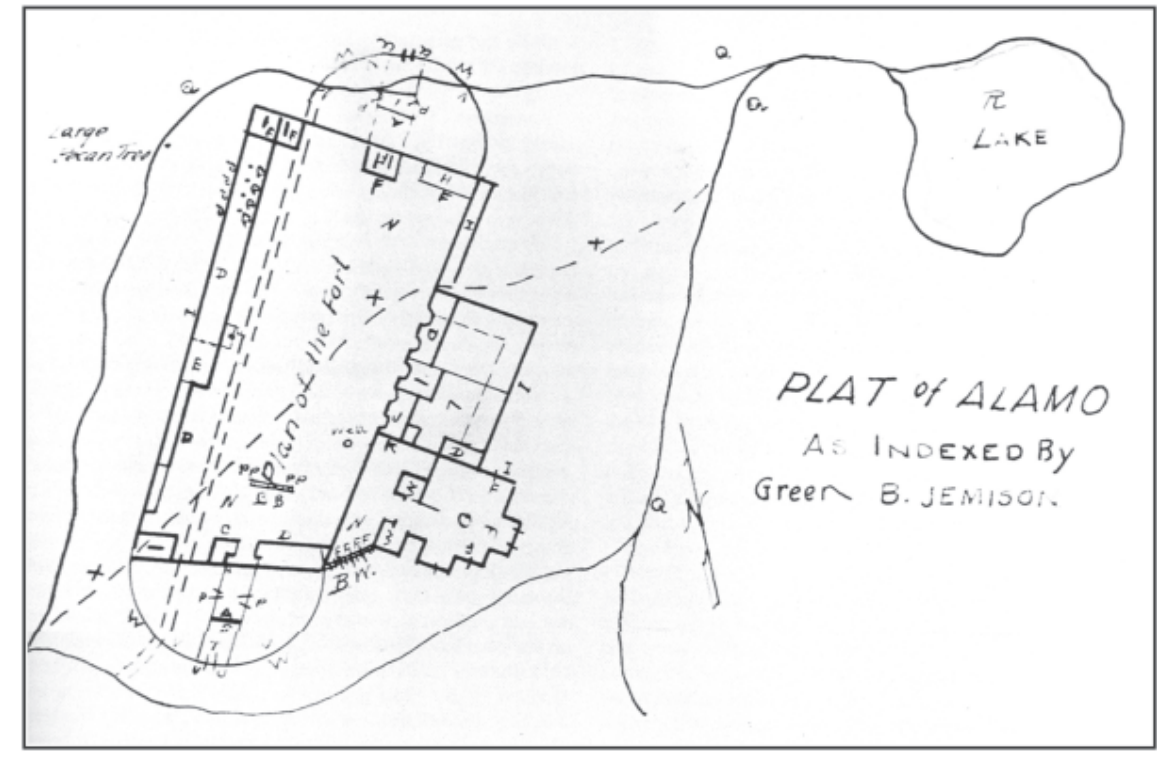

Figure 2-1. Locations of acequias in the vicinity of the Alamo Complex as shown on the Jameson map, 1836. 
necessary to divert the route of this desague around the north side of the mission and route it north to south between the Indian houses in the western area of the mission quadrangle (Figure 2-1). There the desague stayed throughout the life of the mission and beyond the mission's secularization in 1793, until General Cós fortified the Alamo in 1835. He rerouted the desague around the northwest corner and to the south outside the west wall until it joined the original ditch near the southwest corner to drain into the river (Figure 2-1).

Meanwhile, the western ditch continued on its original route past the east wall of the new convento and chapel (Figure 2-1), to the south beneath the later location of the Menger Hotel, and into what would eventually become the Hemisfair grounds. When the U.S. Army moved into the Alamo buildings in 1848 (Cox 1994:12) a section of the Madre ditch was diverted into the area east of the convento to water the horses stabled there. At least two maps have survived showing the location of the ditch at the time of the U.S. Army occupation. The first was completed by Edward Everett in 1848 and the second was possibly completed by Francois Giraud around 1849 for the U.S. Army Figure 2-2). The Army moved out in 1877 (Steinfeldt 1978:175), and the diversion of the water into the Alamo grounds probably ceased then.

Figure 2-2 shows both maps because they provide very different locations of the diversion of the ditch particularly in relation to the Sales Museum building. Everett's map has the diversion ditch entering near the northeast corner of the
Sales Museum, forming the horseshoe shaped turn near the southwest corner of the building and exiting in the center of the south wall. In the 1849 map, the horseshoe bend enters the building just south of the third buttress along the east wall, and exists near the southeast corner of the building (Figure 2-2).

Water continued to run through the western ditch until the city closed the Madre ditch in 1876, although it continued to carry storm water out of the area until it was ordered to be filled in 1905 (Cox 2005:70). However, some downtown portions of the Alamo acequia remained open to be used as storm drains (Cox 2005:71). Apparently this section of the ditch had lain open and ignored when the land directly east of the Alamo was purchased by Peter Thielepape, a wealthy stone mason and merchant. He built a large home directly behind the chapel (James 1938:108).

In 1936 to 1937 restoration of the Alamo buildings and the creation of the Alamo State Park involved the demolition of the home of the former mayor of San Antonio, Wilhelm C.A., Thielepape (1814-1904). To create a suitable setting for the planned garden, the area east of the Alamo was cleared and leveled. When the plan of a new museum was accepted, it became necessary to fill in what remained of the old western ditch that had run across the location of the southeast corner of the building, and to lay out a new route for a restoration of a section of stone-lined ditch slightly farther to the east, where it is today.

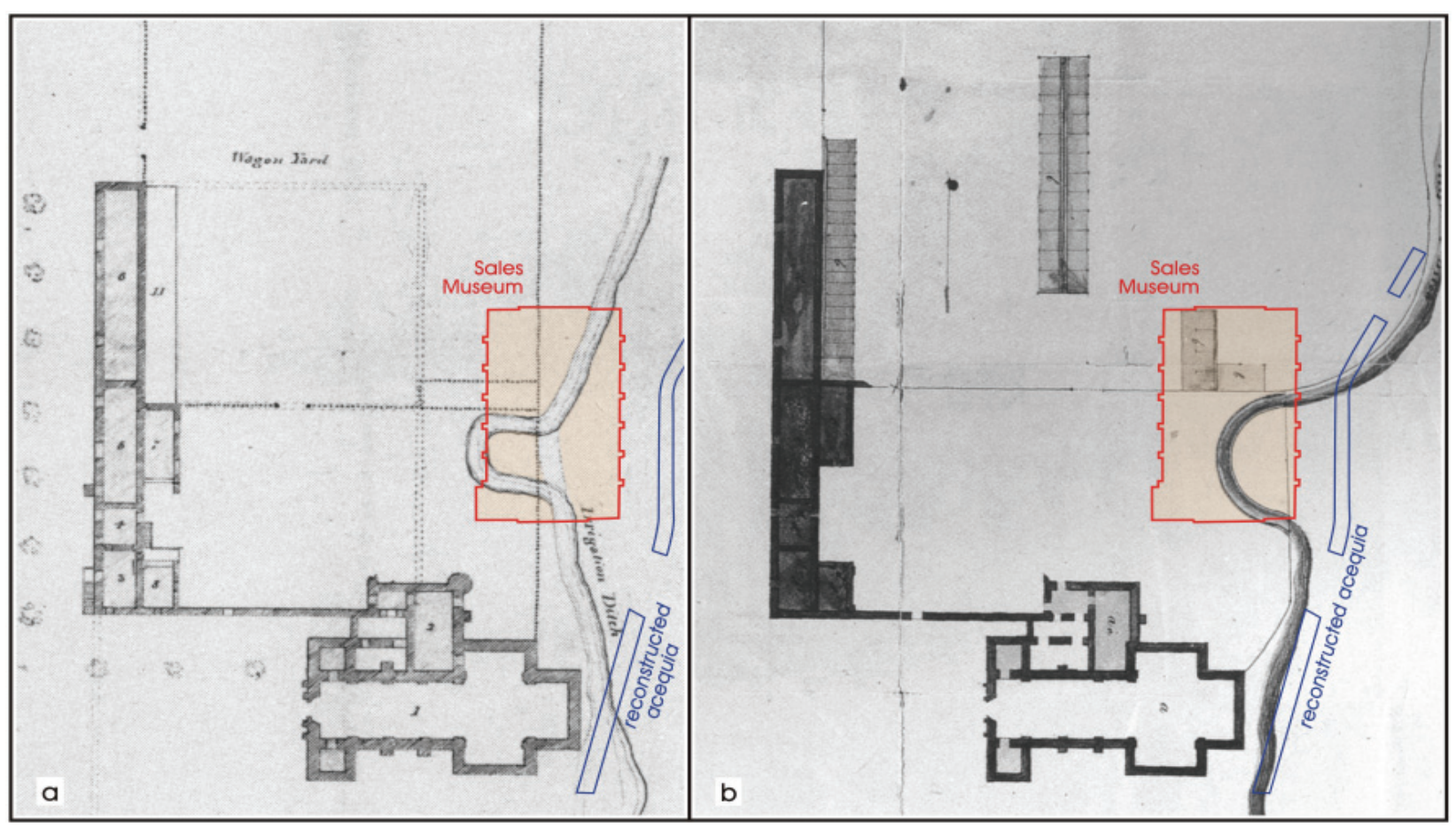

Figure 2-2. Diversion in the acequia route in the vicinity of the Sales Museum: a) Edward Everett, 1848; b) U.S. Army, 1849 (see Nelson 1998:65-66). 


\title{
Chapter 3: Previous Investigations on the Alamo Grounds
}

\author{
Anne A. Fox and Bruce K. Moses
}

A number of archaeological excavations have been carried out within the past fifteen years on the grounds of the Alamo and the Alamo Plaza area. Figure 3-1 provides a graphical summary of the excavations and their locations. The previously conducted projects are numbered and color coded in the map legend for ease of use. The locations of the excavation units have been reconstructed from published project reports, unpublished field notes on file at the CAR curation facility, and discussions with some of the personnel involved in the excavations. Previous investigations relied on 2-3 different and inaccurate base maps resulting in inaccuracies that have been introduced in unit locations and made the creation of a new base map with all units on it rather difficult. Nonetheless, the figure provides a comprehensive, up-to-date, and as precise as records allow, reconstruction of the previous excavations that have occurred in the general area. The summary of the investigations lists the name of the archaeologist and the date of the fieldwork, followed by the publication reference.

In 1866 , excavations by city workmen for the foundation of the Gibbs Building on the northwest corner of Alamo Plaza uncovered several cannon that had been buried in the acequia fill (Figure 3-1 \#1). The property owner, one-time city Mayor Samuel Maverick, used some for decoration at his home and shared the rest with friends. In later years, most of these guns were donated to the Alamo site where they are now on display.

Excavations by workmen in 1935 for planting trees in front of the main Post Office at the north end of the Plaza discovered a mass burial of human skeletal remains estimated at the time to represent 37 individuals (Figure 3-1 \#2). The remains were first interred at San Fernando Cemetery No. 2. In 1957 the remains were moved to another location within the cemetery. In April, 1989, Dr. David Glassman at Southwest Texas State University (now Texas State University) undertook examination and analysis of the remains for the Department of Antiquities Protection in Austin. Glassman determined that the burial contained the remains of "Native Americans of both genders and various adult and subadult ages" (Glassman 1994).

The first official archaeological excavations at the Alamo, in fact the first in San Antonio, were done in June 1966. They occurred after pipeline and foundation excavations within the Alamo walls. These excavations turned up numerous historic and prehistoric archaeological materials prompting the State Building Commission to sponsor test excavations through their Archaeological Program to ascertain the nature and significance of these materials. The excavations were carried out under the direction of John Greer (1967). Work was limited to seven areas within the convento courtyard and the cavalry courtyard directly to the north (Figure 3-1 \#3). A great deal of information was recovered about previous structures of the eighteenth and nineteenth centuries and artifacts related to them. The foundation of an adobe building that apparently predated the construction of the convento was found near the well in the convento courtyard.

As a result of the success of the 1966 excavations, in 1970 test excavations were done by the Texas Archeological Salvage Project in the area north of the D.R.T. Library prior to a planned addition (Figure 3-1 \#4; Sorrow 1972). Although much of the area had been disturbed, part of the east wall of the Alamo acequia and the foundation of a nineteenth-century brick building that had been dug into the center of the fill of the acequia were recorded by this project.

Plans to landscape the north patio of the Alamo in 1973 brought about test excavations in that area (Figure 3-1 \#5; Schuetz 1973). A relatively large area was excavated, revealing the foundations of four rooms that once existed against what was then the east wall of the courtyard. A packed caliche level that was recorded in various locations throughout the excavations appeared to be related to the U.S. Army Quartermaster's occupation. Colonial-period artifacts lay beneath this layer.

Also in 1973, The University of Texas at San Antonio carried out a small excavation east of the restored Alamo Acequia, outside of the Alamo Complex (Figure 3-1 \#6). The excavations encountered foundations of a nineteenthcentury building that was erected in the area after the battle. A brief letter report was submitted to the Texas Antiquities Committee on this work and a short article also was published on the results (Adams and Hester 1973).

Plans for new landscaping on Alamo Plaza in 1975 brought about an archaeological project intended to determine the exact location of the south wall of the original mission and later fortifications (Figure 3-1 \#7; Fox et al. 1976). Backhoe trenching located the footings of the wall and the building that stood against it to the north. An unexpected bonus was the revelation of the north end of a fortification trench or lunette dug under the direction of General Cós in 1835. 


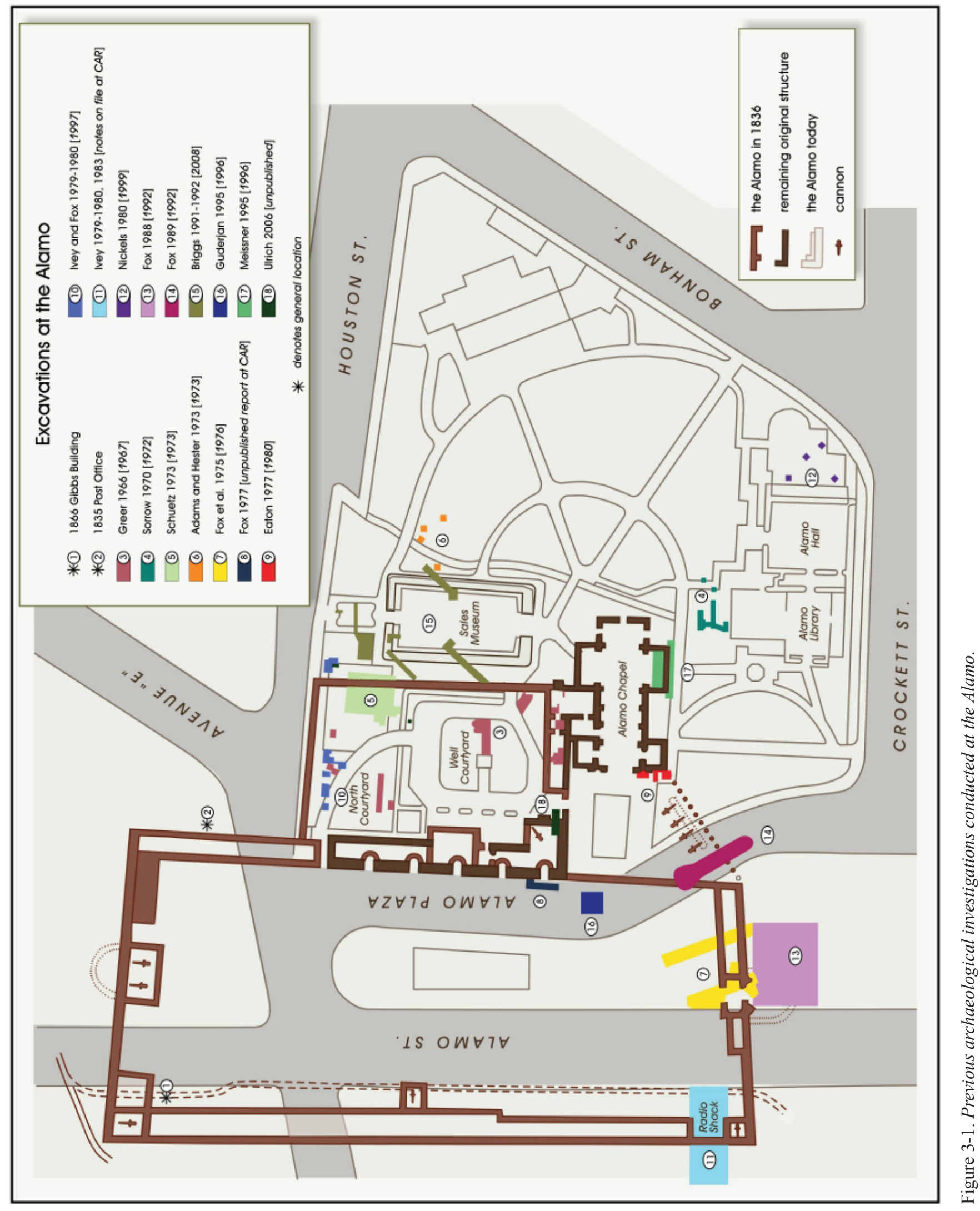


In January, 1977, replacement of flagstone pavement in front of the Long Barracks gave archaeologists another opportunity to test at the Alamo (Figure 3-1 \#8). At the behest of the Texas Historical Commission, Anne Fox of UTSA-CAR oversaw a trenching project intended to find an acequia that had been observed during the Greer excavations in 1966. The trench, dug in the street near the southwest corner of the Long Barracks, was 3.5 meters long and approximately 1.5 meters deep. No acequia was encountered in this N-S oriented trench and it was decided that a shorter trench would be excavated from the north end of the trench perpendicular to the barrack walls to expose and allow inspection of the foundation of the Barracks. A thin caliche layer was observed at a depth of $55 \mathrm{~cm}$ and it was concluded that it probably represented a resurfacing episode dating to the US Army occupation. Spanish Colonial artifacts were noted between 58 and $128 \mathrm{~cm}$ below surface. No 1836 battle-related artifacts or features were observed and no artifact were collected during this investigation. A report was never written on these investigations.

Also in 1977, the desire to replace the flagstone paving at the southwest corner of the Alamo church again required archaeological testing (Figure 3-1 \#9; Eaton 1980). Excavations revealed the method of construction of the foundation of the church. During these excavations, the east end of the palisade fortification built there by General Cós in 1835 was discovered and recorded. The palisade trench yielded artifacts related to the 1836 battle.

Additional archaeology was initiated in 1979 to 1980 by plans to replace the north wall of the north courtyard (Figure 3-1 \#10; Ivey and Fox 1997). After the wall was removed, a series of test units was excavated in relation to the wall's previous location (Figure 3-1), revealing a sequence of previous wall constructions. An 1835 fortification trench was transected by excavation units and found to have been backfilled by wall stones. Among these stones was found the skull of a probable 1836 combatant. Other units revealed an early acequia and an adobe foundation that probably predated the mission's construction.

Also in 1979 (Ivey 1979-1980, 1983), plans for a new city park linking Alamo Plaza to the San Antonio River Walk included a section of the southwest corner of the Alamo grounds. Archaeology in advance of the project was conducted by CAR archaeologists from July of 1979 until June of the following year (Figure 3-1 \#11). The foundations of adobe buildings, the west wall of the Alamo, and the route of the acequia were exposed and later reconstructed above ground in the park. A report on this project has not yet been published.
In late 1979 , the DRT began a project to fix drainage problems around Alamo Hall. The project required the installation of an underground drainage system and grade improvements. Archaeological investigations were conducted by CAR prior to these planned disturbances (Nickels 1999). Four test units were excavated behind Alamo Hall (Figure 3-1 \#12) to locate the foundation of the home of the former San Antonio Mayor Wilhelm Carl August Thielepape that was demolished sometime in the mid-to late-1930s. The excavations did locate remnants of the stone foundation and parts of the adobe walls that they supported. Prehistoric, Spanish colonial, and later artifacts were recovered from disturbed contexts.

Further plans for landscaping on Alamo Plaza initiated an archaeological field school by UTSA students conducted by Dr. Fred Valdez with the assistance of the author in 1988. Work was concentrated in the area south of the south wall gate (Figure 3-1 \#13; Fox 1992) and consisted of removal of the fill in the lunette trench and a perpendicular trench that ran to the east, and careful mapping of the area.

The following year, another UTSA field school was conducted in the same general area, this time conducted by Dr. Joel Gunn and the author (Figure 3-1 \#14; Fox 1992). An area adjacent to the western edge of Alamo East Street was carefully excavated, revealing the continuation of the second trench as it ran parallel to the south wall, as well as what appeared to be an area of springs that once existed in the plaza (Fox 1992).

The renovations associated with the Alamo Sales Museum brought on the 1991-92 investigations by Alton Briggs (Figure 3-1 \#15; reported herein). The results of these excavations are reported herein and they are shown on the summary map to indicate their position vis a vis all other investigations.

Unlike most scientifically driven projects carried out on the Alamo grounds, the 1995 "Alamo Wells Project," (Figure 3-1 \#16) is one of the better known although least scientifically driven excavations at the site (Guderjan 2003). Garnering world wide press coverage, the "Tesoro del Alamo Preservation Society" headed by amateur researcher Frank Buschbacher sought to locate a stash of silver bullion in a well at the site which had been revealed to him by a clairvoyant. Seeking to find the well as recorded on the problematic Green B. Jameson map, Buschbacher surveyed the plaza with divining rods, GPR and electromagnetic sensors and finally settled on an area where two large circular anomalies had been observed. The treasure hunters hired archaeologist Thomas H. Guderjan of St. Mary's University and Guderjan and his team excavated a $15^{\prime}$ ' square area to a depth of 30 inches. A final probe of the subsurface was made by backhoe 
through the sterile soil to a depth of $15^{\prime}$ below the surface. The excavation, supported by T-Shirt sales and an exclusive film rights agreement with the television program, Unsolved Mysteries, produced some modest data from the mission period, but very little on the 1836 battle and no well.

Plans in 1995 to install metal plates into the south wall of the Alamo church in hopes of controlling the rising of groundwater in the wall required archaeological investigations both inside and outside that section of the wall (Figure 3-1 \#17; Meissner 1996). Although a few Colonial-period artifacts were found, the deposits contained mostly nineteenth- and earlytwentieth-century artifacts. An excavation against the wall in the church interior exposed stone and clay rubble beneath the flagstone floor. Collapse of the bottom of these excavations in several locations revealed a few human bone fragments, probably representing human burials in the area. The holes were immediately backfilled.

To date the last investigations that occurred within the walls of the Alamo were those carried out by CAR as part of The University of Texas' Department of Anthropology Summer Archaeology Field School in 2006. These investigations concentrated in different areas of the courtyard north of the Alamo Chapel (Figure 3-1 \#18). The results of these excavations are to be written-up following the issuance of this report. 


\title{
Chapter 4: Research Design and Archaeological Field and Laboratory Methods
}

\author{
Steve A. Tomka
}

This chapter provides a description of the research design that directed the investigations associated with the Alamo Sales Museum and summarizes the field and laboratory methods employed. The information relating to these aspects of the project was pulled together from the draft report prepared by Briggs, project-related correspondences, excavation profiles and copies of a few field notes received from the Texas Historical Commission.

\section{Research Design}

The two reports produced by Briggs $(1993,1998)$ include a one page research design section that addresses under individual paragraphs aspects of the scope-of-work for the remodeling of the Alamo Sales Museum. Five aspects are addressed: (1) project permitting; (2) archaeological excavation methods; (3) conservation of artifacts; (4) curation of artifacts; and (5) technical report. Based on the brief research design and the sequence of THC consultations during the project, it appears that a comprehensive research design that outlined the principal tasks that needed to be accomplished as part of the project had not yet been formulated at the time of the first investigations associated with the planned project. This may be due to the fact that at the time the initiation of the first construction-related activities on site, it was not know whether any intact cultural deposits still remain under the Sales Museum.

According to the draftreportprepared by Briggs, archaeological work at the Museum consisted of five principal tasks: 1) preasbestos abatement testing under the building; 2) abatement monitoring; 3) mechanical testing of the project area; 4) pre-basement excavation impact area testing; and finally, 5) monitoring of the excavation of the basement and elevator tunnel and recovery of selected artifacts. These five tasks were conducted in three principal phases of work. Because no one knew the specific construction methods of the Museum and what level of impact they may have had on cultural materials, the goal of the first phase of work was to determine whether archaeological materials were even present under the Museum. And, if materials were found, would they be harmed in the process of asbestos abatement that was to occur before construction. Only the pre-asbestos abatement testing was performed during this phase of work. The second phase of work centered on recovering archaeological materials that were to be impacted by the excavation of an access pit for the asbestos abatement teams under the north wall of the Museum. These excavations were to also document the stratigraphy in this portion of the project area. These investigations were a precursor to task two, the abatement monitoring. The goals of the third phase of investigations was to document what was the extent of intact cultural deposits under the Museum and what was their research potential. To pursue these goals, large scale mechanical testing of the area adjacent to and under the museum was undertaken (Tasks 3 and 4 listed above). No information detailing the monitoring of the basement and elevator tunnel was found in the Briggs reports or few field notes available. However, a brief VHC video produced by Lone Star Archeological Services on the project does show the excavation of the large and deep trench and crews clearing the east wall of the massive trench in preparation for profiling.

\section{Field Methods}

The first archaeological investigations associated with the planned expansion of the Alamo Sales Museum began in July 1991. These investigations, the pre-asbestos abatement testing carried out on the $29^{\text {th }}$ and $30^{\text {th }}$ of the month, were performed in advance of anticipated asbestos abatement that was to be conducted under the Sales Museum. The investigative strategy was worked out in conjunction with Mark Denton of the Texas Historical Commission. The strategy called for the excavation of a minimum of twelve $50 \times 50 \mathrm{~cm}$ test units dug to a depth exceeding 15 centimeters below surface $(\mathrm{cmbs})$ and the collection of two surface samples (Figure 4-1). In the absence of field notes, it is not feasible to determine what was to be the terminal depth of these units. The fieldwork that was undertaken once this strategy was agreed to resulted in the excavation of 13 test units and the collection of two surface samples. The excavations and sampling were carried out by staff of Bexar Insulation Company, Incorporated (BICI) under the direction of Alton K. Briggs. All of the collected material was passed through $1 / 4$ inch mesh screens and bagged separately.

Following the completion of the pre-abatement testing and the analysis of the artifacts, Briggs concluded that (1) “... while there is cultural material (artifacts) beneath the Sales Museum, removal of the asbestos under the structure would not significantly alter or harm the archeological deposits." In addition, Briggs also concluded that "...while artifacts were recovered from under the building, no strata which might indicate that an undisturbed deposit exists under the structure was observed in any of the sample locations. The thirteen test units encountered disturbed soil (Briggs 


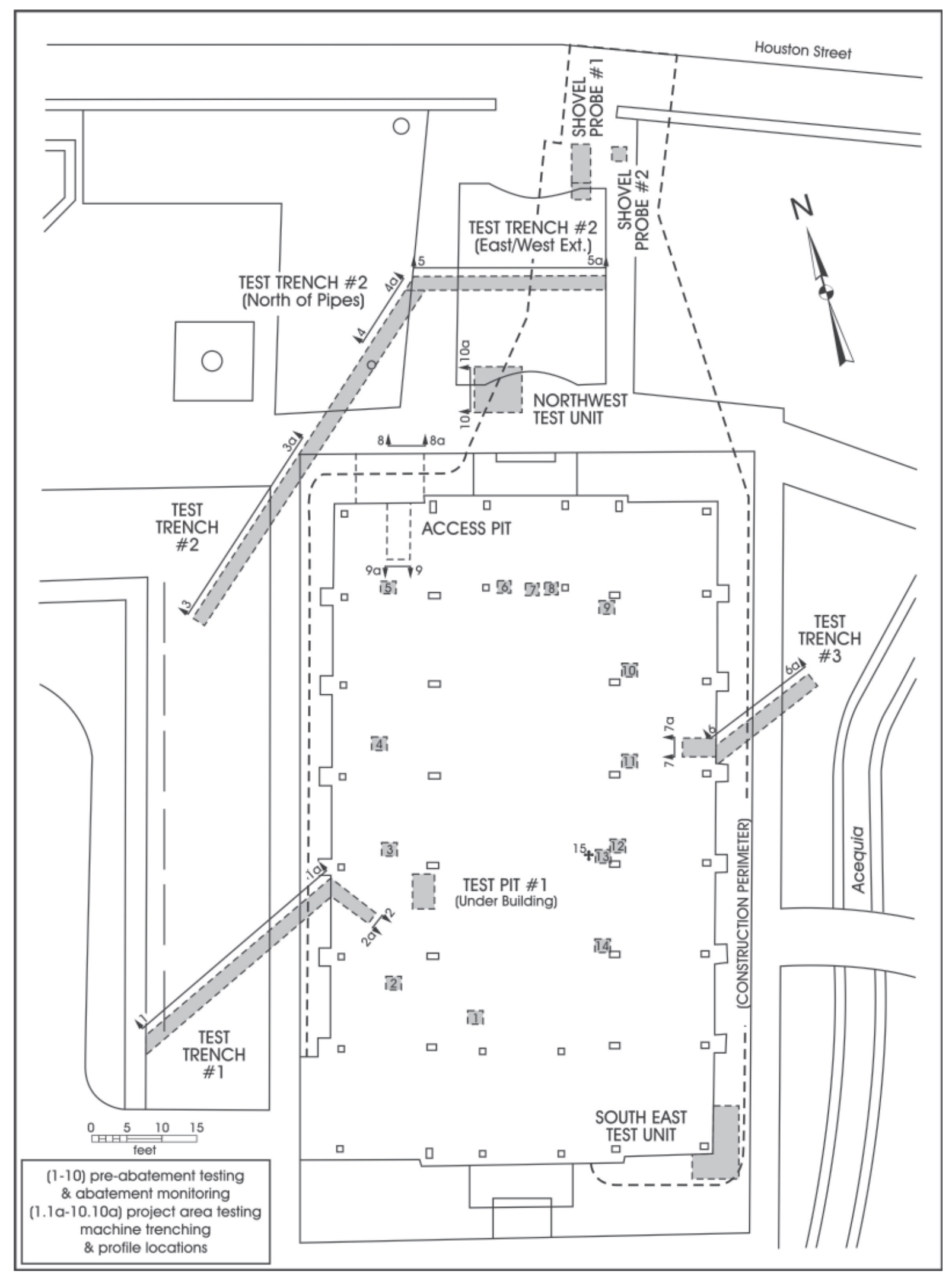

Figure 4-1. Location of units excavated by Lone Star Archeological Services under and in the vicinity of the Sales Museum. 
1998:27). Briggs interpreted the matrix as representative of 1930s construction debris derived from the construction of the Alamo Sales Museum, at least in the upper 10 centimeters of the stratigraphy (Briggs 1998:25).

On August 20, Briggs met with Mark Denton and J. Barto Arnold of the Texas Historical Commission to discuss the findings of the pre-abatement investigations and additional archaeological efforts that may be warranted in association with the planned remodeling of the Sales Museum. Five specific recommendations were made:

1) Because historically significant artifacts were uncommon in the upper $10 \mathrm{~cm}$ of loose construction fill, the removal of this fill should not adversely affect the underlying archaeological deposits.

2) The samples of artifacts recovered from below the disturbed construction debris document that $19^{\text {th }}$ century and perhaps earlier deposits may be present under the Sales Museum. The likelihood of intact $19^{\text {th }}$ century and earlier deposits warrants further systematic investigations to identify additional archaeological materials and features.

3) To provide entry space for the abatement team and equipment under the building, the TAC recommended the hand-excavation of one $2 \times 4$ meter test pit dug to sterile. It was proposed that this unit be located on the north side of the Sales Museum, near its western corner. In addition to access space, the goal of this unit was to provide data on the depth, character and content of the archaeological deposits that were to be affected by the remodeling of the Sales Museum.

4) To collect information on the depth, character and content of the archaeological deposits to be affected by the construction of the French drain, the TAC recommended the hand-excavation of two trenches, each measuring at least one meter in width and five to six meters in length. The trenches were to begin at the footing of the western wall of the Museum and extend to the west being excavated to sterile deposits.

5) To provide information on the nature, depth and content of archaeological deposits north and west of the Museum, the TAC recommended the hand-excavation of a one-meter wide trench of an appropriate length. As before, the trench was to be dug to sterile deposits. This area also was to be impacted by the installation of the French drain.

Prior to the actual initiation of the removal of the asbestos from under the ASM, it was necessary to construct an avenue of access to the space under the ASM to allow access by asbestos abators and their specialized equipment. Given that future subsurface impacts associated with the construction of an elevator access tunnel were projected at the north end of the building, it was decided that the access pit would be excavated immediately adjacent and under the north end of the ASM.

On September 30, Mr. Denton of the THC undertook brief subsurface investigations outside of the Sales Museum in an area measuring approximately $5 \times 20$ feet immediately under the north building footing beam and extending under the building itself. The scope of these investigations was to determine the depth of overburden or fill that was placed in this area on top of the $19^{\text {th }}$ century living surface. It was hoped that the overburden could be removed by Alamo personnel prior to professional archaeological excavations that would concentrate on $19^{\text {th }}$ century and earlier deposits. Following the inspection by Mr. Denton, the area was to be excavated to provide the entryway to the Asbestos Abators to remove the asbestos fallen from the heating ducts and steam pipes installed under the building. The asbestos removal was to concentrate on 4-5 foot wide strips under the heating pipes and also was to remove asbestos from elsewhere under the building until the space under the structure tested negative for asbestos.

No information is available on Denton's excavations. It appears that Denton identified undisturbed deposits at a depth that cannot be determined due to lack of notes. Once the zone of apparently undisturbed deposits was identified, the test pit was backfilled with the disturbed overburden.

The next phase of archaeological investigations was associated with the asbestos abatement carried out by personnel from Bexar Insulation Company, Incorporated (BICI). The first step of the abatement consisted of the excavation of an entryway pit near the base of the north wall at the northwest corner of the ASM building. This pit appears to have been in the same location as Denton's exploratory unit. The pit was to allow access under the building to permit the abatement of the asbestos insulation fallen from the heating ducts. This excavation occurred in the spring of 1992.

The abatement team, using shovels and also apparently a backhoe, excavated an access pit (North Access Pit) opening beneath the base of the north wall of the Museum (Figures 4-1 and 4-2), in an area previously investigated under the supervision of Archaeologist Mark Denton of the Texas Historical Commission. This unit is identified as the Access Pit (and/or North Access Pit or North Access Pit Number One) on excavation plans compiled by Briggs. The size of 


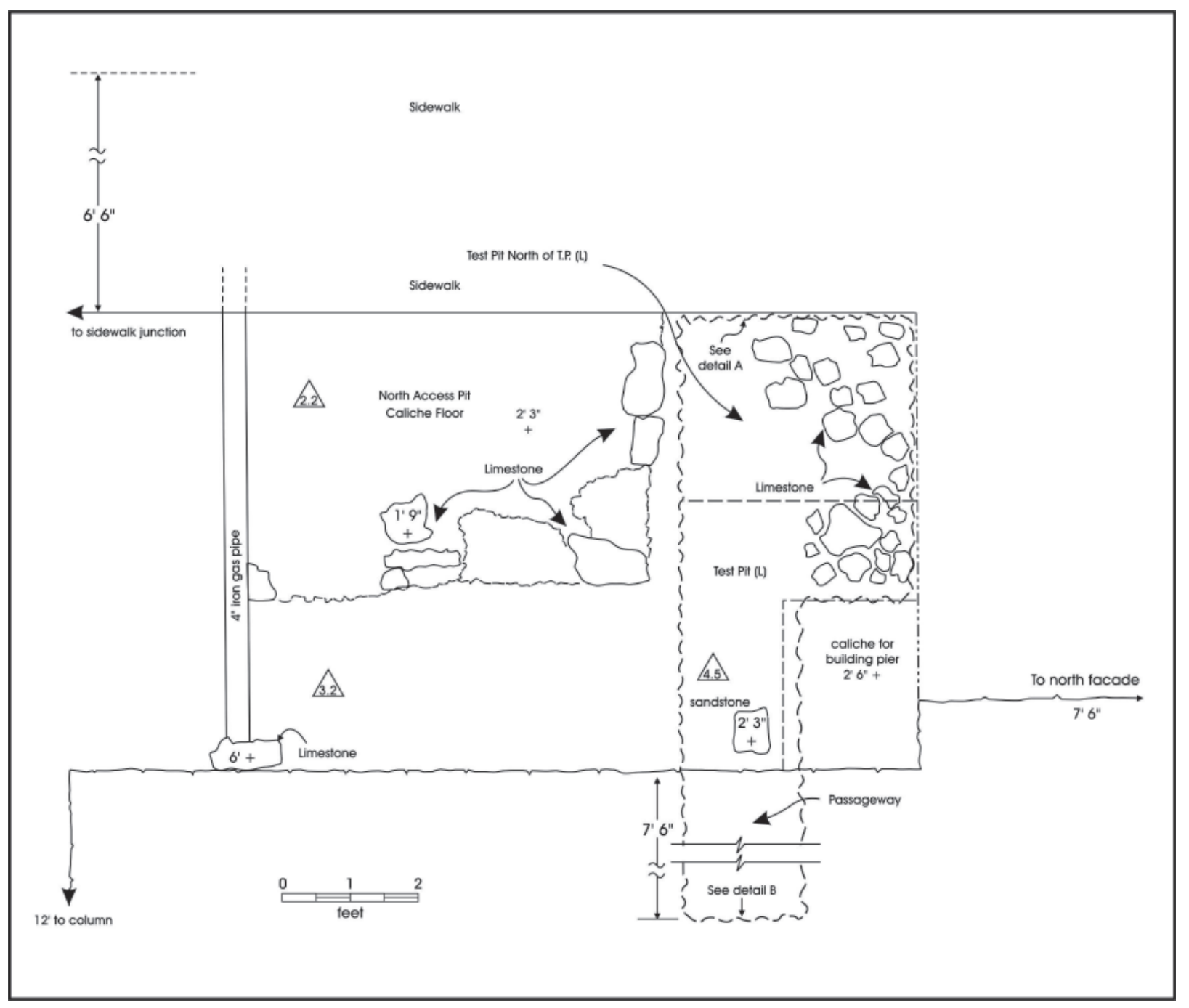

Figure 4-2. Detail of units associated with the Access Pit at north end of Sales Museum.

this initial pit was approximately $5.5(\mathrm{E}-\mathrm{W}) \mathrm{x} 4(\mathrm{~N}-\mathrm{S})$ feet. To allow access to the crawl space under the building, this pit was subsequently enlarged by the removal of soil from under the concrete beam - the structural foundation near the northwest corner of the ASM. Through this enlargement, the North Access Pit may have grown to 6 (E-W) x 6.7 (N-S) foot unit.

Following these excavations, Briggs indicates that the “... entrance hole was lined with clear plastic sheeting which went under the building. Outside the building, a small structure was constructed, using $2 \times 4$ studs, opaque sheet plastic and duct tape. This plastic-walled construction was attached to the plastic-lined opening under the building. A small mobile trailer and vacuum unit were installed on the opposite side of the small structure. When the system was completed, air pressure inside the entire system could be regulated to prevent the exfiltration of asbestos into the open air." With this enclosed system in place and dressed in tyvek suits and double respirators the asbestos abatement team crawled under the building and removed all loose asbestos and asbestos contaminated materials by hand and with vacuum hoses. The final stage of the abatement consisted of the spraying of a consolidating agent on top of the surface under the ASM assuring that all small asbestos particulates would be sealed under a blanket of material rather than becoming airborne during subsequent work under the building.

After the asbestos abatement was completed using a mix of mechanical and hand-excavation, the original Access Pit was enlarged through the excavation of two adjoining units (Figure 4-2). One of these units, identified as "Test Pit L" started out as a $3.8 \times 3.5$ foot unit adjoining the access pit to its west. The second unit, identified in Briggs' maps as "Test Pit North of T.P. L" measured 2.5 (N-S) x 3.5 (E-W) feet. A detailed profile of the north wall of this pit was drawn. 
Together the three units enlarged the original excavation to an area covering roughly ten feet by 6.7 feet. Instead of stopping at the base of the north wall of the ASM, Test Pit L continued as a narrow 2 -foot wide trench under the building for a distance of 7.6 feet and served as the entrance under the building to allow access to the crawl space beneath the building. This long and narrow unit is at times identified as the passageway in Briggs' notes (Figure 4-2). The south wall of this long trench was also profiled.

The staff of the Texas Antiquities Committee recommended that additional trenches be excavated around the perimeter of and extending under the ASM because to that point in the archaeological project, the deposits under the ASM had been sampled in only one area,. Several trenches on the west, north, and east sides of the building were laid out (Figure 4-1). These were excavated by machine and by hand, all soil removed being passed through screens, either dry or with water. In addition, a $5 \times 5 \mathrm{ft}$ square test pit was handexcavated to the north of the museum, between the Access Pit and the East-West portion of Trench 2.

Trench 1 was positioned on the west side of the ASM. It was excavated by machinery and was three feet wide. It began at the WPA wall and ran 35 feet to the northeast where it reached the west wall of the ASM and continued under the wall for 8 feet in a southeasterly direction to one of the supporting piers of the Museum poured in 1935. The excavations in the vicinity of the pier provided details about the construction of the piers and served to approximate the area that was minimally disturbed around each of the 32 piers found under the ASM. The north wall of the longest segment of the trench and the south wall of the eight-foot segment under the building were profiled.

To determine the level of disturbance, in the spaces between the piers, a $4 \times 6$ foot unit (Test Pit Number One) was excavated under the building (Figure 4-1). It was located inside one of the excavation trenches from the 1937 construction (Briggs 1993:15). The unit was excavated using picks and trowels and the soil was removed in five-gallon buckets and water screened (1993:15). However, Briggs' catalog lists no artifacts recovered from this unit. The only mention of recovery is associated with provenience SM130 (Test pit under the building). The catalog indicates that the only recovery associate with this catalog number is a 20 gallon bucket of matrix), however, no individual artifacts are listed. None of the walls of this unit were profiled based on the notes. Therefore, this unit will not be discussed in the results chapter of this report.

Trench 2 was also three feet wide and dug by machinery. It also began at the WPA wall on the west side of the ASM building, passed just under the northwest corner of the Museum, and continued to the NE for approximately 55 feet. At its north end, it joined a 25 foot segment that was oriented E-W. Three distinct segments of the north wall of Trench 2 have been profiled. They include a 30 -foot segment beginning at the southern end of the trench, a 10-foot segment at its northern end, and the entire 25 -foot north wall of the eastwest extension of the trench.

Trench 3 was excavated on the east side of the Museum. It extended diagonally to the northeast from the building to a point near the present location of the acequia, just less than 18 feet in length. Once it reached the base of the wall, a fivefoot segment extended under the building. The north wall of the longer segment and the west wall of the short segment under the building were profiled.

A number of other units are shown on his Figure 4-1 including: (1) shovel probe \# 1 and Shovel probe \# 2; (2) northwest test unit; and (3) southeast test unit. The outcomes of these excavations is not reported in great detail.

\section{Laboratory Methods}

The collections from the Briggs investigations have undergone two distinct phase of laboratory processing. The first was carried out by Briggs and his staff in preparation for the analysis and reporting. The second phase occurred after the boxes of artifacts were received at the CAR laboratory. This phase consisted of the re-cataloging of the collections and their preparation for curation. Therefore, we first present a brief summary of the laboratory methods and processing carried out by Briggs. This discussion is followed by a summary of the laboratory work and curation preparation carried out by the CAR staff.

Briggs (1993:17-19) indicates that as the artifacts were recovered either from the screen, from an excavation surface or from hand- and machine-excavation trenches, they were placed in plastic bags. The bags were assigned individual lot numbers and once in the lab each lot was processed by itself to reduce the possibility of mixing of artifacts from different proveniences. The cultural materials from each bag were separated into analytical categories including: bone, Native American pottery, Mexican pottery, majolica, British ceramics, metal, glass, lithics, and other.

Artifacts were washed in tap water and brushed when necessary to remove encrusted dirt. Subsequently they were rinsed in clean water and allowed to dry in an air conditioned space. Once dry, the artifacts were bagged, labeled, and set aside by lot for cataloging and analysis (Briggs 1993:17). 
Faunal remains underwent more extensive processing. Washed, damp bones were immersed in a $10 \%$ solution of polyvinyl acetate for several hours, and subsequently allowed to dry on screen. Once dried, the specimens were bagged, labeled, and set aside by lot for analysis. The lots were shipped to William McClure for identification.

Select copper and bronze artifacts that were heavily corroded underwent a four-step laboratory processing technique. First they were brushed and/or washed to remove dirt and loose corrosion. Next each artifact was placed in a glass container and immersed in a solution of Alkaline Rochelle Salts for an average of seven days. Following the salt-solution bath, the artifacts were immersed in a $30 \%$ formic acid solution long enough to remove the red cuprous oxide below the green corrosion products. Finally, the specimens were washed thoroughly in distilled water. As with all other artifacts, these select few copper and bronze artifacts were then dried completely and sealed in plastic bags with appropriate labels.

A single heavily rusted metal artifact, a pocket knife with a bone handle, was cleaned through electrolytic reduction. The technique works by producing hydrogen that reacts with the corrosion and reduces the rust and removes it from the hard metal. The treatment of the artifact occurred between March 8 and April 20, 1993 (Briggs 1993:18). Once the process was completed, the artifact was washed in distilled water in an ultrasonic tank. The bone handle was treated with polyvinyl acetate as all other bone artifacts and the metal parts were brushed with cellulose lacquer (Briggs 1993:19).

Ceramic artifacts were cleaned as described above and subsequently separated into broad analytical categories including aboriginal earthenwares, Mexican pottery, majolicas, Rhenishwares, British ceramics, and Texas stonewares. Lithic artifacts were divided into arrow points with five distinct varieties of Guerrero points, and tools, bifaces, unifaces, utilized flakes, gunspalls, Spanish Colonial specimens, and gunflints.

The draft reports produced by Briggs included four appendixes containing inventories of the cultural materials excavated during the project. Appendix A is the inventory of specimens recovered from under the Sales Museum during the pre-asbestos testing (July 29-30, 1991). Appendix B contains the inventory of items recovered from the trenches and test pits excavated during the spring of 1992. Appendix $\mathrm{C}$ is the inventory of specimens recovered from test pits and excavations between September and October, 1992 and Appendix D is the inventory of items recovered from the tunnel excavation that occurred on December $2^{\text {nd }}, 1993$.
These inventories/catalogues are arranged by artifact numbers. Excavation units or features are presented in the sequence they were found and/or investigated. Within each trench, artifacts are listed by lot, which corresponds to a general vertical and horizontal location. Each artifact was assigned a number which identified the site from which it came, its location by feature and lot, what kind of artifact it is, and which artifact it is within the group.

Artifacts in each lot were presented in the following categories: bones and teeth, ceramics, aboriginal pottery, Mexican pottery, British ceramics, majolicas, construction materials, and lithics.

Once the boxes of materials arrived to the CAR laboratory the staff unpacked the boxes in order to create a catalogue of the contents of the boxes and inspect the state of the artifacts and determine the laboratory processing that they had undergone. This initial inspection revealed that the materials had undergone substantial processing but unfortunately the cataloguing was not completed according to the standards and requirements of the CAR curation facility. Specifically, the tags that accompanied the artifact bags were not acid-free and the labeling was sometimes completed with ballpoint pens rather than pencil. In addition, the artifact bags were sandwich bags rather than archival-quality plastic bags.

In addition, and more importantly, the cataloguing of the ceramics in particular identified many incorrect typological identifications and/or assignments. Therefore, it was felt that to ready the collections for analysis by the CAR staff, the best approach would be to re-catalogue the collections and subsequently re-package and re-tag all proveniences. During the re-cataloging process, the previous catalog numbers were removed from each artifact and the artifacts were relabeled with unique lot numbers.

During the laboratory processing carried out at the CAR, all cultural materials received from the DRT and all records generated during the project were prepared in accordance with federal regulation 36 CFR part 79, and THC requirements for State Held-in-Trust collections. Additionally, the materials were curated in accordance with current guidelines of the CAR. Artifacts were repackaged in 4-mil zip locking archival-quality bags. Acid-free labels were placed in all artifact bags. Each label contained provenience information and a corresponding lot number written in archival ink, with pencil or laser printed. The original tags were kept and included with the materials curated. Tools and ceramics were labeled with permanent ink over a clear coat of acrylic and covered by another acrylic coat. In addition, a small sample of unmodified debitage from each lot was labeled with the 
appropriate provenience data. All artifact categories, with the exception of faunal remains and unmodified lithic debitage were analyzed. The results of the faunal analysis completed by McClure were entered into the project database. All lithic tools were analyzed and no analysis of unmodified lithic debitage was completed. All artifacts recovered during the Sales Museum project are part of the project database. Following approval by the Texas Historical Commission, all faunal remains identified to taxa were retained but all unidentified mammal bone was discarded. The discarded faunal remains amounted to a total of 23,002 pieces weighing 39,802 grams. All unidentified metal, amounting to 1,222 pieces, weighing 11,351 grams also was discarded as were 1,262 nails, weighing 5,007 grams. All identified metal objects and square nails were retained. Finally, to explore the contents of some of the soil samples recovered by Briggs, and also reduce the bulk of the soils to be curated, the CAR staff floated a total of 44 soil samples. All fine and heavy fractions as well as all other soil samples that were not floated are curated with the rest of the collections.

In addition to the boxes of artifacts received from the Alamo, CAR also received photocopies of project-associated documentation from the Texas Historical Commission. This documentation included copies of the Briggs draft report dated April 1993, and final report dated January 1998. Thirty to thirty-five pages of these reports consisted of discussions of project background and summaries of the excavations and results. The bulk of the remainders of the reports consisted of four appendixes including Appendix A (1998:89-92), the inventory of archeological specimens recovered from under the Alamo Sales Museum on 29-30 July, 1991, Appendix B (1998:93-207), inventory of specimens recovered from trenches and test pits during the Spring, 1992, and Appendix C (1998:208-262), the inventory of specimens recovered from test pits and excavation units between September 21 and October 9, 1992. Appendix D (1998:263-287) consisted of the inventory of specimens recovered from the tunnel excavations between December 2, 1992 and April 10, 1993.

The documents at CAR's disposition also included copies of some correspondences and transmittal documents between Robert Morris Architectural Associates, Inc., the THC and the Alamo. Field notes received at the CAR included 38 pages of faunal analysis results. These pages contained the faunal identifications for the specimens obtained from the Sales Museum excavations. We assume that these notes were William McClure's faunal analysis notes. We also received three pages of catalog sheets related to chipped lithic artifacts recovered from the site. Finally, four pages of general notes on Mexican ceramics also were included. These notes consisted primarily of reference materials on Mexican ceramics rather than analysis notes. The final 54 pages consisted of handwritten specimen inventories of the ceramics recovered during the project. The final group of 76 pages of field notes consisted of a mix of daily notes (6 pages), lab procedure discussions and catalog sheets (29 pages), a list of profiles produced during the project and profile descriptions (23 pages) for a limited number of profiles, and field profile sketches (16 pages) for a select number of units. In a separate mailing from the THC CAR also received the originals of nine profiles, consisting of profiles 1-1a thru 9-9a. A list of profiles among the notes suggested that 16 to 19 profiles were produced during the project. The final material received from the THC was a VHS tape of snippets of excavations carried out during the Sales Museum Project.

With the exception of the materials that were discarded with THC's concurrence, all other cultural materials retained during the Briggs investigations and received by the CAR, as well as copies of all records received from the THC, and all records generated during the laboratory processing and analysis of the collections, are permanently housed at the CAR curation facility. 



\title{
Chapter 5: Results of Excavations
}

\author{
Steve A. Tomka, Anne A. Fox, and Antonia L. Figueroa
}

The paucity of excavation notes has required intense concentration in an attempt to reconstruct the intent of the archaeological crew. Reconstruction of excavation levels throughout this report has been accomplished by careful study of what information is included in the few field notes and the catalog plus the notes included with the profiles and plan drawings. The resulting descriptions and discussions of the excavations and the artifacts recovered are as close to the truth as we were able to come with the information available.

Although Briggs has stated that these excavations were done in 10-centimeter levels (personal communication via email November, 2004), there is no evidence for this in the artifact catalog or the unit profiles. It does appear that the hand excavations were done in $10 \mathrm{~cm}$ levels. However, the backhoe operator who excavated the trenches has stated that he was directed to dig in 18-inch levels (Fulghum personal communication November, 2004). Since the catalog refers to Levels 1 through 4 for the trench excavations, and the maximum depth of the trenches according to the profile drawings is approximately 6 feet, it seems likely that the 18inch measurement is more accurate and will therefore be used for many of the trench descriptions in this report where actual depth measurements are not available.

Discussion and analysis of the artifacts recovered from the various excavation units does not include the animal bone recovered, since it does not contribute to the dating of the stratification, although the total numbers of the bone often exceed any other artifact type. In each discussion of the excavation units, the first part is a description of the stratification as reported by the profile, followed by a discussion of the artifact totals recovered from each level or analytical unit and what this information may mean in relation to the profile information. Figure 4-1 presents the location of each unit excavated during the Sales Museum investigations.

\section{Phase I}

The pre-abatement testing efforts involved the excavation of $1350-x-50 \mathrm{~cm}$ units to a depth of $15-30 \mathrm{~cm}$ according to the original SOW. In addition, surface collections were made from two additional $50-\mathrm{x}-50 \mathrm{~cm}$ locations under the Sales Museum. The units were inside of the support piers and sampled the entire circumference of the area under the museum structure. The first four inches of the $50 \times 50 \mathrm{~cm}$ units beneath the museum consisted of a loose, friable mixture of dust, sawdust, mortar, lime and sand identified by the workers as "construction fill." Below this was approximately two feet of disturbed gravels that contained both colonial and $19^{\text {th }}$ century artifacts. The artifact inventory for these excavations does not indicate levels within the units.

Table 5-1 provides a breakdown of the artifacts recovered during these excavations. Units 8 and 10, located near the northern end of the Museum yielded the largest quantity of artifacts followed by Unit 1 and 13, under the southern and east-central portion of the structure, respectively. The most common artifacts consist of unidentified metal and cut nails, followed by animal bones and window glass fragments. While chert gravels are also relatively common $(n=25)$, they probably reflect construction debris. Wire nails are the only other artifact category that occurs in abundance $(n=22)$. Ceramics occur in low frequencies and consist of a mix of Mexican lead glazed, ironstone, whitewares, and Colonial tin glazed ceramics. Examination of the collections revealed that Units 1 through 6 produced primarily constructionrelated artifacts, such as window glass, nails, and plaster. The succeeding Units 7 through 13 also included occasional ceramic sherds and bottle glass and metal fragments as well. Units 14 and 15 were surface collections of no particular importance. In all, it appears that the area beneath the museum as a whole did not produce artifactual information of value to the structural history of the museum area. No details are available regarding the vertical distribution of the artifacts. However, the mix of large numbers of cut and wire nails and ceramics clearly indicates heavy mixing at least in the deposits sampled during the pre-abatement excavations.

Following the processing and inspection of the artifacts, Briggs concluded (1993:12) that "...while artifacts were recovered from under the building, no strata which might indicate that an undisturbed deposit exists under the structure was observed in any of the fifteen test pits. All fifteen of the test pits encountered disturbed soils."

\section{Phase II}

This phase of work focused on recovering archaeological materials that were to be impacted by the excavation of the access pit for the asbestos abatement teams under the north wall of the Museum. These excavations were to also 
Table 5-1. Artifacts Recovered from 50-x-50 cm Test Units Excavated Under the Sales Museum

\begin{tabular}{|c|c|c|c|c|c|c|c|c|c|c|c|c|c|c|c|c|}
\hline \multirow{2}{*}{ CLASS } & \multicolumn{16}{|c|}{ Unit } \\
\hline & 1 & 2 & 3 & 4 & 5 & 6 & 7 & 8 & 9 & 10 & 11 & 12 & 13 & 14 & 15 & Totals \\
\hline Animal Bone & & 3 & 1 & 1 & 2 & 2 & & 5 & 2 & 5 & & 3 & & 3 & 1 & 28 \\
\hline Battery Carbon Insert & & & & & & & & & & & 1 & & & & & 1 \\
\hline Bottle Glass & & & & & & & & 3 & & 1 & 1 & & 1 & & & 6 \\
\hline Brick & & & & & & & 1 & 6 & & & 1 & & & & & 8 \\
\hline Chert Pebbles & & & & & & & 2 & 4 & & 6 & 2 & 3 & 6 & 2 & & 25 \\
\hline Clay Nodules & & & & & & & & & & & 1 & & & & & 1 \\
\hline Clay Paver & & & & & & & & & & & & 1 & 1 & & & 2 \\
\hline Colonial Ceramic: Lead Galzed & & & & & & & 1 & & & 3 & & & & & & 4 \\
\hline Colonial Ceramic: Tin Glazed & & & & & & & & & & & & & 1 & & & 1 \\
\hline Cut Nail & 2 & & & & & & 2 & 16 & & 4 & 4 & 4 & 3 & & & 35 \\
\hline Debitage & & & & & & & & & & & & & & 1 & & 1 \\
\hline English Ceramic: Stoneware & & & & & & & & & & & & 1 & 2 & & & 3 \\
\hline English Ceramic: White & & & & & 1 & & & 2 & & & & & & & & 3 \\
\hline Fence Staple & & & & & & & & & & & & & 1 & & & 1 \\
\hline Horse Shoe & & & & & & & & & & & 1 & & & & & 1 \\
\hline Leather & & 1 & & & & & & & & & & & & & & 1 \\
\hline Other Ceramics: Terra Cotta & & & & & & & & & & & & & 1 & & & 1 \\
\hline Other Ceramics: Unidentified & & & & & & & & & & & & & & & & 0 \\
\hline Plaster & & 2 & & & & & & & & & & & 2 & & & 4 \\
\hline Plate Glass & & & & & & & & & & & & & 1 & & & 1 \\
\hline Sandstone/ Limestone & & & & & & & & & & & & 4 & 1 & & & 5 \\
\hline Sheet Metal & 1 & & & & & & & & 4 & & & & & & & 5 \\
\hline Slag & & & & & & & & 2 & & & & & & 1 & & 3 \\
\hline Unidentified Glass & & & & & 1 & & & & & & & & & & & 1 \\
\hline Unidentified Metal & & & 7 & 1 & & & & & & 26 & & 1 & & & & 35 \\
\hline Window Glass & 23 & & & 1 & & & & 1 & & & & & 2 & & & 27 \\
\hline Wire Nail & 2 & 5 & & 5 & 1 & & & 7 & & & & & 2 & & & 22 \\
\hline Wood & 3 & & & 1 & & & 5 & & & & & 1 & & & & 10 \\
\hline Total & 31 & 11 & 8 & 9 & 5 & 2 & 11 & 46 & 6 & 45 & 11 & 18 & 24 & 7 & 1 & 235 \\
\hline
\end{tabular}

document the stratigraphy immediately north of and under the north wall of the Sales Museum. Initially an access pit was excavated in an area overlying Denton's test-inspection. This access pit was later enlarged into a passage way.

\section{The Access Pit}

The size of the initial North Access Pit (and/or Access Pit Number One) pit was approximately 5.5 (E-W) x 4 (N-S) feet (Figure 4-2 and 5-1). This pit was subsequently enlarged by the removal of soil from under the concrete beam of the Sales Museum. Following this enlargement, the North Access Pit may have grown to $6(\mathrm{E}-\mathrm{W}) \times 6.7(\mathrm{~N}-\mathrm{S})$ foot unit.
After the asbestos abatement was completed using a mix of mechanical and hand-excavation, the original North Access Pit was further enlarged through the excavation of two adjoining units. One of these units, identified in Briggs' profiles (Brigg's Figure 10) as "Test Pit North of T.P. L" measured 2.5 (N-S) x 3.5 (E-W) feet. The second unit, identified as "Test Pit L" started out as a $3.8 \times 3.5$ foot unit adjoining the units to its north and west. Together the three units enlarged the original excavation to an area covering roughly ten feet by 6.7 feet. Instead of stopping at the base of the north wall of the ASM, Test Pit L continued as a narrow 2-foot wide trench under the building for a distance of 7.6 feet and served as the entrance under the building to allow access to the crawl space beneath 


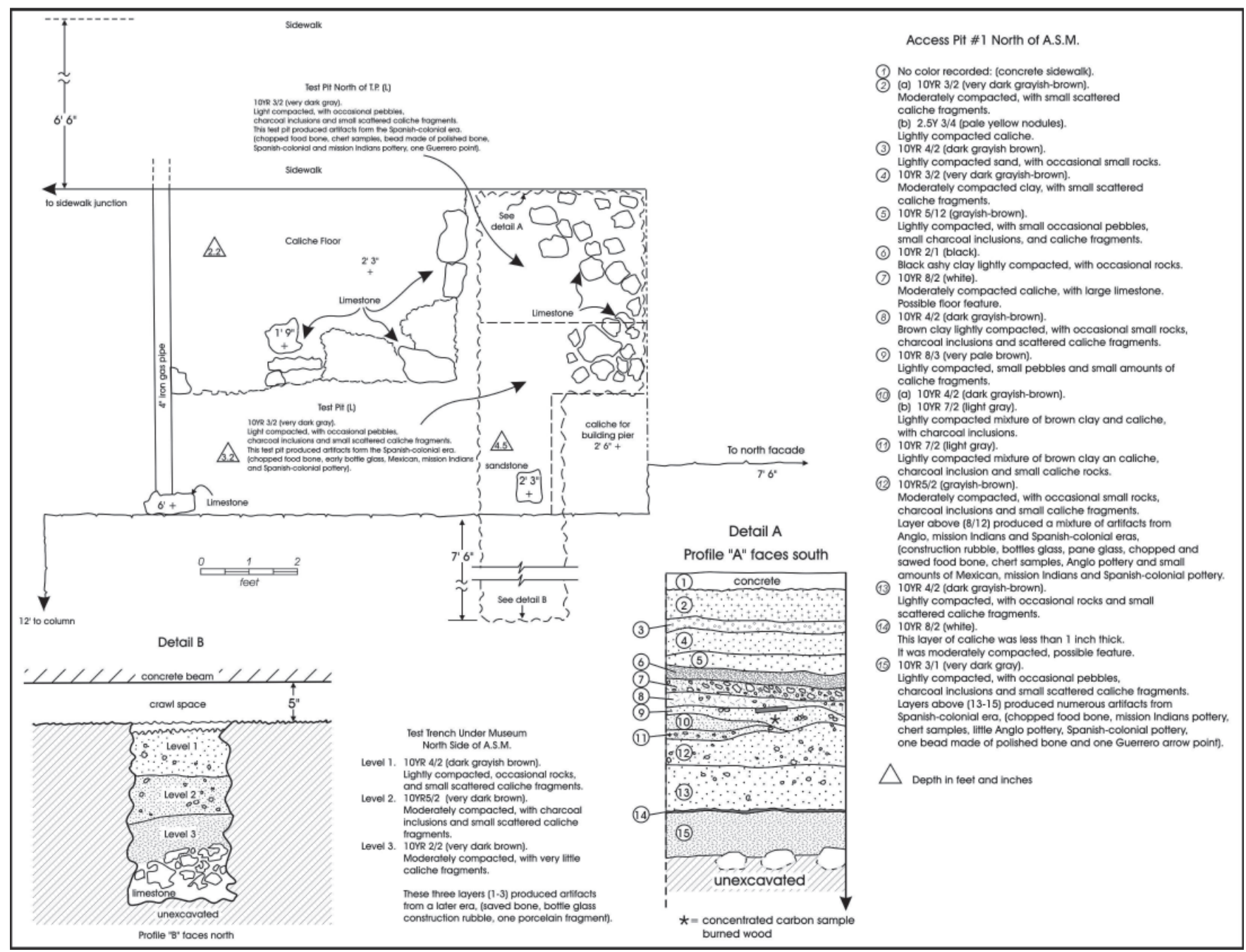

Figure 5-1. Access Pit units with profiles.

the building. The south wall of this long trench was also profiled.

An approximately 1 meter wide section of the north wall of the Test Pit North of T.P. (L) has been profiled from surface to a depth of 1.3 meters below surface. This profile revealed 15 strata (Figure 5-1). Briggs states (1993:13) that nine of the strata underlie a charcoal lens (Layer 6) that may be the same as that recognized by M. Schuetz during her excavations not far west of these units (1973). The excavations also revealed what was likely one of the pits excavated in 1937 to pour one of the nearby concrete piers of the building. A portion of the pit, backfilled with caliche, was exposed in the southeastern corner of Test Pit (L). The northwest portion of the access pit revealed a feature that was initially discovered with a backhoe bucket as it disrupted two limestone blocks. Specifically, several tabular limestone rocks were set on edge along the eastern and southern margins of this unit. The area to the north of this alignment consisted of a flat compact caliche floor. Once the architectural feature, which appears to represent one corner and floor of a structure, was noted, it was exposed, cleared and photographed.

Briggs' catalogue (1998:200-207) indicates that there are six proveniences attributed to the North Access Pit excavations. Due to the lack of field notes, and based simply on the catalogue, it has not been possible to determine the horizontal position of these proveniences. Similarly, only hints are provided in the catalogue regarding the vertical relationship of the proveniences to each other. Based on these few indicators, we have divided the materials into three analysis units representing three excavation levels. Table 5-2 identifies these proveniences as well as the analysis units and levels defined by CAR.

No information was available to the CAR staff regarding the thickness of the levels, and with the exception of the descriptive 
Table 5-2. Proveniences from Access Pit Excavations and Analysis Units Defined by CAR

\begin{tabular}{|c|l|c|c|}
\hline $\begin{array}{c}\text { Provenience/ } \\
\text { Unit }\end{array}$ & Catalog Description & $\begin{array}{c}\text { Analysis } \\
\text { Unit/Level }\end{array}$ & $\begin{array}{c}\text { Lot } \\
\text { Number }\end{array}$ \\
\hline SM5-1 & Level 1, below floor & I/1 & $1991-217$ \\
\hline SM5-2 & $\begin{array}{l}\text { Below building, } \\
\text { below floor }\end{array}$ & I/1 & $1991-218$ \\
\hline SM5-3 & $\begin{array}{l}\text { Below building, } \\
\text { below floor }\end{array}$ & I/1 & $1991-219$ \\
\hline SM5-4 & $\begin{array}{l}\text { L-pit, north of } \\
\text { A.S.M. }\end{array}$ & II/2 & $1991-220$ \\
\hline SM5-5 & Under museum & II/2 & $1991-221$ \\
\hline SM5-8 & $\begin{array}{l}\text { Level 2, inside } \\
\text { access pit }\end{array}$ & II/2 & $1991-224$ \\
\hline SM5-7 & Under building & II/2 & $1991-223$ \\
\hline SM5-6 & $\begin{array}{l}\text { Level 3, test pit } \\
\text { north of L pit }\end{array}$ & III/3 & $1991-222$ \\
\hline SM5-9 & $\begin{array}{l}\text { Level 3, inside } \\
\text { access pit, below } \\
\text { caliche layer }\end{array}$ & III/3 & $1991-225$ \\
\hline
\end{tabular}

notation in four of the proveniences regarding levels, no clear indication of relative depth is available regarding the other five proveniences. Nonetheless, the analysis of the artifacts seems to indicate that we are close to the actual stratification in the pit.

Faunal remains not withstanding, the largest artifact category from this excavation area was flat and miscellaneous glass combined $(n=78)$ followed by unidentified metals $(n=56$; Table 5-3) and lead glazed ceramics $(n=36)$. Analysis Unit I contains the highest quantity of glass, nails of all kinds (i.e., cut, wire, and undivided; $n=53$ ), and unidentified metals. In contrast, Analysis Unit II contains consistently lower numbers of these artifact categories, while lead glazed $(n=23)$ and majolica ( $\mathrm{n}=14$; tin glazed) ceramics, and Native American $(n=12)$ sherds occur in greater numbers. Faunal remains are most abundant in Analysis Unit II and remain common in the deepest of the Analysis Units, III. This distributional pattern suggests that the two deepest analysis units contain primarily colonial period materials. In the notation associated with the north wall profile of the access pit (Figure 5-1), Briggs also remarked that layers $13-15$ produced primarily Spanish colonial artifacts including chopped faunal remains, Goliad ceramics, Mexican pottery, a Guerrero arrow point, a "polished bone bead" and little in terms of English wares.

Of the 866 artifacts from these nine proveniences, $300(35 \%)$ could be assigned to one of three temporal associations, representing either colonial $(n=85), 19^{\text {th }}$ century $(n=214)$, or modern $(n=1)$ artifacts. As Table 5-4 indicates, colonial period artifacts are most common $(n=55,65 \%)$ in Analysis Unit II. While $19^{\text {th }}$ century artifacts are present in all analysis units, they are most common in Analysis Unit I ( $\mathrm{n}=148,69 \%)$. The third and lowest analysis unit contained comparatively few artifacts, but even here, $19^{\text {th }}$ century items outnumbered Colonial Period materials.

\section{The Passageway}

Workers doing further investigations dug a 3-ft.-wide passageway from the entrance opening toward the south beneath the building to allow entrance into the crawl space Figures 4-1 and 4-2. A profile of the south end of this passageway was drawn and, in contrast to the north wall profile (Figure 5-1) it shows only three distinct zones. The first two levels are described as machine graded and while the first layer is only lightly compacted, the second layer is noticeably compact. In addition, an eastwardly dip in the top of Layer 3 , is identified by Briggs as having been likely caused by a grader or maintainer. The base of Layer 3 consists of loose limestone that may also represent construction debris.

While a relatively large number of artifacts were recovered from the Access Pit units, the Briggs catalogue (1998:239) indicates that only one provenience unit is associated with the excavation of this passageway, namely 41BX6SM-15. An animal bone and a piece of Colonial pottery was recovered from these excavations. A note by Briggs on the south wall profile of this passageway indicates that the three strata identified in the profile produced "... artifacts from a later era." Also, the note indicates that "animal bones, bottle glass, construction ruble, and one porcelain fragment" were saved during the excavations. The low quantity of artifacts suggests that the matrix was not screened or that because it was recognized as disturbed, it was not screened and collected.

\section{Phase III}

The investigation of the bulk of the deposits that were located under the Sales Museum structure occurred during this phase of the project. The Texas Antiquities Committee recommended that additional trenches be excavated around the perimeter of and extending under the Sales Museum. Three trenches located on the west, north, and east sides of the building were mechanically excavated. In addition, a $4 \mathrm{x}$ 6 foot (Test Pit Number One) test unit under the structure and a $5 \times 5 \mathrm{ft}$ square test pit to the north of the museum between the Access Pit and the East-West portion of Trench 2, were hand-excavated (Figure 4-1).

\section{Trench 1}

Trench 1 was positioned on the west side of the ASM (Figure 4-1). It was excavated by machinery and was three feet wide. 
Table 5-3. Artifacts Recovered from the North Access Pit by Analysis Unit

\begin{tabular}{|c|c|c|c|c|c|}
\hline \multirow{2}{*}{ CLASS } & \multirow[b]{2}{*}{ Data } & \multicolumn{3}{|c|}{ Analysis Unit } & \multirow[b]{2}{*}{ Grand Total } \\
\hline & & $\mathrm{I}$ & II & III & \\
\hline Activity: Gaming & COUNT & 1 & 1 & & 2 \\
\hline Activity: Toy & COUNT & 1 & & & 1 \\
\hline Bead & COUNT & & & 1 & 1 \\
\hline \multirow{2}{*}{ Bone } & COUNT & 81 & 282 & 132 & 495 \\
\hline & \begin{tabular}{|l|} 
WEIGHT $(\mathrm{g})$ \\
\end{tabular} & 184 & 639.88 & 361.92 & 1185.8 \\
\hline Brick & \begin{tabular}{|l|} 
COUNT \\
\end{tabular} & 2 & 2 & & 4 \\
\hline Button & COUNT & 1 & & & 1 \\
\hline Colonial Ceramic: Lead Glazed & COUNT & 11 & 23 & 2 & 36 \\
\hline Colonial Ceramic: Tin Glazed & COUNT & 5 & 14 & 7 & 26 \\
\hline Colonial Ceramic: Unglazed & COUNT & & 4 & & 4 \\
\hline Cut Nail & COUNT & 17 & & & 17 \\
\hline Debitage & COUNT & 4 & 18 & 20 & 42 \\
\hline English Ceramic: Stoneware & COUNT & 1 & & & 1 \\
\hline $\begin{array}{l}\text { English Ceramic: White } \\
\text { Earthenware }\end{array}$ & COUNT & 5 & 8 & & 13 \\
\hline Flat Glass & COUNT & 17 & 1 & & 18 \\
\hline Glass & COUNT & 50 & 8 & 2 & 60 \\
\hline Lithic Tool & COUNT & 1 & & 1 & 2 \\
\hline Metal & COUNT & 1 & & & 1 \\
\hline Metal Fastener & COUNT & 4 & & & 4 \\
\hline Metal: lead & COUNT & 1 & & & 1 \\
\hline \multirow{2}{*}{ Mussel Shell Fragment } & COUNT & & 3 & 1 & 4 \\
\hline & WEIGHT $(\mathrm{g})$ & & 2.35 & 0.53 & 2.88 \\
\hline \multirow{2}{*}{ Mussel Shell Umbo } & COUNT & & & 1 & 1 \\
\hline & WEIGHT $(\mathrm{g})$ & & & 0.59 & 0.59 \\
\hline Nail & COUNT & 21 & 6 & & 27 \\
\hline Native American Ceramic & COUNT & & 12 & 1 & 13 \\
\hline Other Ceramic & COUNT & & 1 & & 1 \\
\hline Other Ceramic: Porcelain & COUNT & & 1 & & 1 \\
\hline Other Rock & COUNT & 2 & 6 & & 8 \\
\hline Paver & COUNT & 3 & & & 3 \\
\hline Sewer Pipe & COUNT & 1 & & & 1 \\
\hline \multirow{2}{*}{ Unidentified metal } & COUNT & 48 & 8 & & 56 \\
\hline & WEIGHT $(\mathrm{g})$ & 106.99 & 23.58 & & 130.57 \\
\hline Wire Nail & COUNT & 20 & 2 & & 22 \\
\hline Total COUNT & & 298 & 400 & 168 & 866 \\
\hline
\end{tabular}

It began at the WPA wall and ran 35 feet to the northeast where it reached the west wall of the ASM and continued under the wall for 8 feet in a southeasterly direction to one of the supporting piers of the Museum poured in 1935. The excavations in the vicinity of the pier provided details about the construction of the piers and served to approximate the area that was minimally disturbed around each of the 32 piers found under the ASM. The north wall of the longest segment of the trench and the south wall of the eight-foot segment under the building were profiled.

The profile of the north wall of Trench 1 shows that an approximately 3.5 -foot long segment of Trench 1 , immediately 
Table 5-4. Breakdown of North Access Pit Artifacts by Temporal Affiliation

\begin{tabular}{|l|c|c|c|c|}
\hline \multirow{2}{*}{ AU/Level } & \multicolumn{3}{|c|}{ Period } & Grand \\
\cline { 2 - 5 } & 19th century & Colonial & Modern & Total \\
\hline $\mathrm{I} / 1$ & 148 & 18 & & 166 \\
\hline $\mathrm{II} / 2$ & 43 & 55 & 1 & 99 \\
\hline $\mathrm{III} / 3$ & 23 & 12 & & 35 \\
\hline Total COUNT & 214 & 85 & 1 & 300 \\
\hline
\end{tabular}

adjoining the WPA was excavated to a depth of just over 3 feet (Figure 5-2). This portion of the trench may represent a portion of the construction trench dug for the WPA wall. The next 6.5 feet of the trench vary in depth between 2-3 feet below surface. This section may have been excavated using a combination of hand- and mechanical means. From approximately 10 to 19 feet east of the WPA wall, the trench was excavated to about 10 feet below surface. Given the depth and shape of the walls, this section appears to have been mechanically excavated or hand-excavated using shovels. From 19 to approximately 23 feet the depth of the trench was roughly 2 feet and from there to its end adjacent to the west wall of the Sales Museum, the depth varied from 4-5.5 feet below surface. These final 10 feet adjacent to the Sales Museum wall appear to have been mechanically excavated. The short southeasterly section extending under the structure was excavated to a depth of approximately6 feet below surface. The trench cross-section and shape of the walls are characteristic of hand-excavated units.

Eleven stratigraphic layers were documented in the north wall profile of the SW to NE trending portion of the trench. Briggs' report (1993:14-15) indicates that the excavations of the longer segment of the trench exposed three "prepared earth floors from the Spanish Colonial mission period. The lowest floor is gray dirt mixed with some clay and charcoal, along with archeological specimens. The upper two floors are similar in their construction, although more carefully prepared. Layered one atop the other like a cake, the upper two are separated with a thin layer of caliche." Unfortunately, the captions of the stratigraphy illustrated in the profile of Trench 1 do not identify all three floors (Figure 5-2). One of the floor notations is found in the middle of the first layer and the second floor is identified as being on top of Layer 3. It is unclear whether these are the upper two floors since no caliche layer is shown to separate them from each other. Layers 4 and 6 are described as heavily and moderately compacted, respectively, and at least the higher of the two is described as being rich in artifacts. A thin layer of clay loam fill separates these two layers suggesting perhaps that they represent re-flooring episodes and the artifacts accumulated on them.
Briggs' profile mentions two other features in this trench. One of the features consists of a line of limestone rocks immediately adjacent to the base of the WPA wall. These limestone fragments may represent debris from WPA construction activities. No interpretation or detailed discussion of this feature could be found in the few notes available to CAR staff. A more interesting feature is what Briggs identifies as the acequia ditch/trench that was relocated inside the wagon yard by the Army sometime around 1846 (Figure 5-2). Although the acequia is not labeled as such on the profile (Figure 5-2), Briggs (1993:15) indicates that the "... acequia area is disturbed by a pipeway on the western side. On the eastern side, the excavation has been filled with $20^{\text {th }}$ Century soil and debris...." It is likely that Briggs is referring to the pipe trench that is found approximately eight feet from the base of the Sales Museum wall and contains a pipe approximately 3.5 feet below the surface (Figure 5-2). Unfortunately, given the absence of an acequia label on the profile, it is difficult to discern whether this interpretation is correct. Also, it is likely that he is basing his interpretation as much on the profile as the expectation that the acequia should be in this position given the Everett's 1848 map.

The short trench segment that extended beneath the museum encountered six layers (Figure 5-2). The relationship of these stratigraphic layers to the ones shown in the north wall profile cannot be determined. The roughly 3.5 -foot tall profile is topped by a thin stratum of caliche. Below this were two strata of gray soil containing caliche, beneath which were found two strata of gravel in grayish brown soil.

In terms of the artifacts recovered from the trench, the profile captions do provide some details. Layers 1 and 2 appear to contain primarily modern artifacts. A mix of $19^{\text {th }}$ century artifacts and some colonial ceramics are present in Layers 3 and 4 . The next three strata contained a mixture of colonial and $19^{\text {th }}$ century artifacts with English ceramics occurring in low numbers. The bottom two strata of dark gray brown soil contained colonial artifacts. Layers 8 and 9 also contained artifacts but in low numbers and they consisted exclusively of Spanish colonial materials. The deepest of the layers was sterile "bedrock" (Briggs 1993:16).

Based on the catalog provided in Briggs (1993), it has been determined that 29 proveniences represent or contain materials recovered from Trench 1. These proveniences, their catalog descriptions and the analysis units and levels they have been assigned to are presented in Table 5-5. The 28 proveniences were grouped into seven analysis units. The analysis units in turn could be grouped into three vertical strata, Level 1, Level 2 and a set of proveniences that as far as it could be 


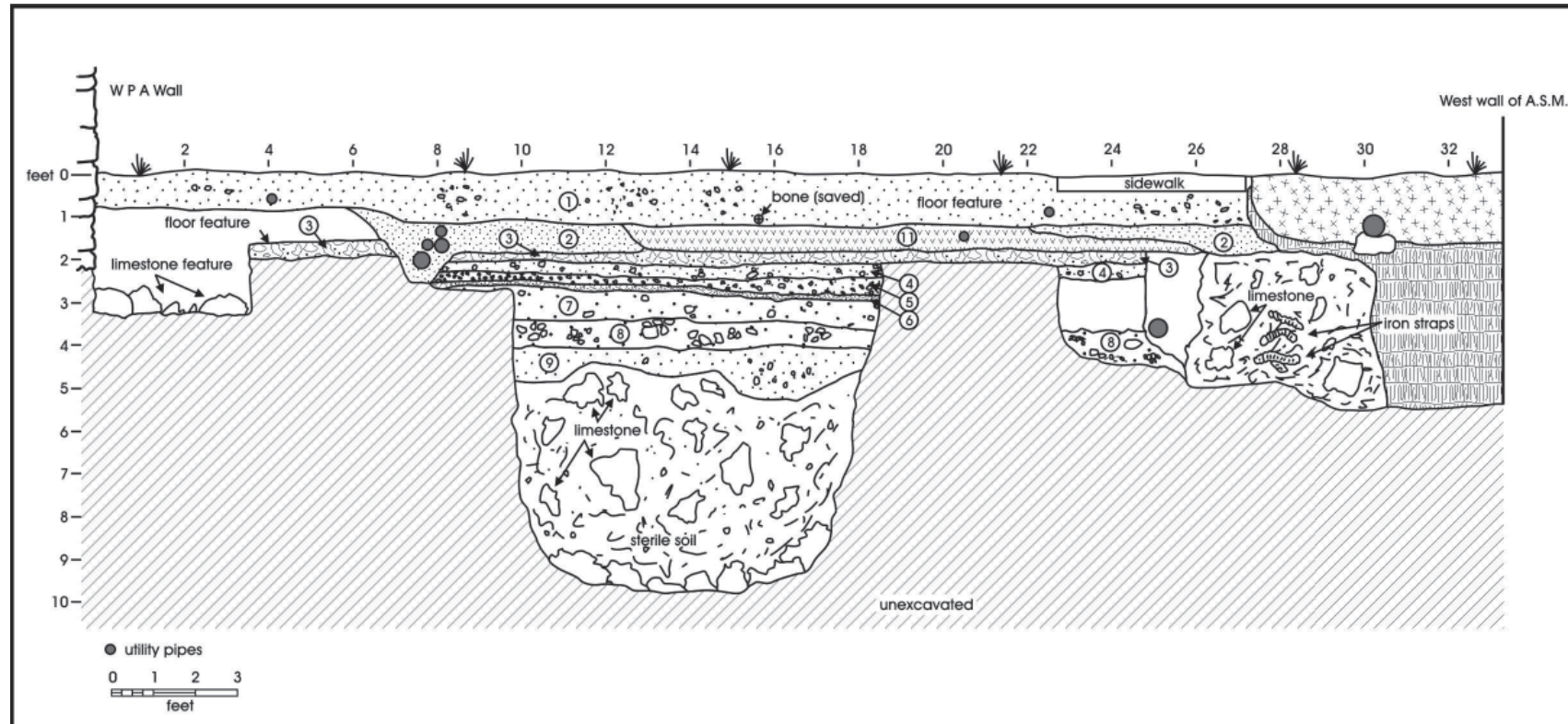

Test Trench 1

(1) 10YR 3/1 (very dark gray, fine sandy loam, blocky, numerous inclusions of pebbles, roots, sawed bone fragments near bottom of zone, disturbed modern soil)

(2) 10YR $3 / 3$ (dark brown loam, inclusions of pebbles, few roots, fill dirt to utility ditch, homogeneous structure)

(3) 10YR $6 / 3$ (pale brown) and 10YR $5 / 2$ (mixed loam and caliche, numerous pebbles, rocks, charcoal and ash, possible fill, lightly compacted)

This layer produced artifacts from a later era (sawed bone, bottle glass, nails, iron, pane glass, Mexican and Indian pottery, some Spanish-colonial pottery (majolica), Anglo ceramics)

(4) 1OYR $8 / 1$ (white) and 10YR4/2 (dray gray brown) clay loam, heavily compacted, white and gray colors varied throughout, contain small gravel, charcoal flecks (bottle glass,

pane glass, nails, iron, chopped and sawed bone, Anglo, Mexican, Indian and Spanish-colonial pottery)

(5) 10YR $4 / 2$ (clay loam with rock fragments, numerous charcoal, larger than above, lightly compacted, possible fill)

(6) 10YR $5 / 2$ (grayish-brown) and d10YR 7/3 (very pale brown) mix, reddish stains occasionally, moderately compacted, charcoal flecks
(7) 10YR 4/2 (dark grayish-brown) and 10YR 7/2 (light gray), loam and caliche mixed, lightly compacted, includes rock fragments and charcoal fragments, possible fill, All three layers above (5/7 produced large amounts of Spanish-colonial artifacts (chopped food bone, early bottle glass, little Anglo pottery, large amounts of Mexican, Indian and Spanish-colonial pottery, chert samples, jewelry)

(8) 1OYR $4 / 1$ (dark gray clay loam, contains light scatter pebbles, occasionally lager rock fragments, moderately compacted)

(9) 10YR 3/2 (very dark grayish-brown clay loam, includes occasional rock fragments, moderately compacted)

These two layers (8-9) produced Spanish-colonial artifacts, except the deposit was not as rich

(10) 10YR 7/4 (very pale brown clay loam, includes weathered limestone fragments, loosely compacted)

(11) 10YR 6/4 (light yellowish-brown, sandy, possible fill dirt, contains sand of 10YR 5/8, loosely compacted)

This layer produced (sawed bone, nails, iron, pane glass, bottle glass, Anglo pottery, some Mexican, Indian pottery, construction rubble, slate pencil, glass bead, shell)

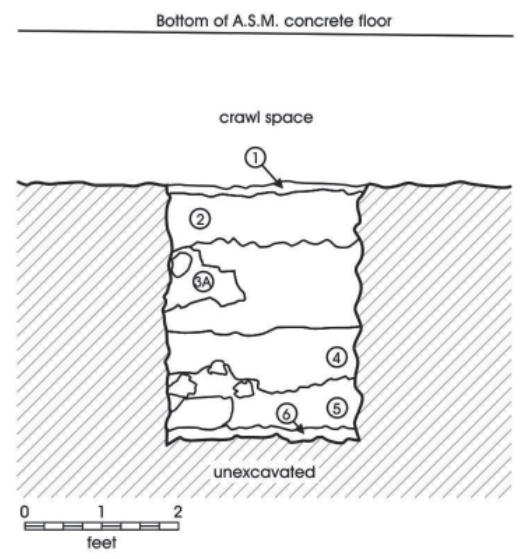

Test Trench 1 under A.S.M.

(1) 7.5 YR N8/1 (white caliche with light gray mix 7.5 YR N7/11)

(2) 1OYR $6 / 2$ (light brownish-gray with caliche)

(3) 1OYR $3 / 1$ (very dark gray with caliche)

(3A) 1OYR $4 / 1$ (dark gray with caliche inclusions)

(4) $10 Y R 4 / 1$ (dark gray with pea gravels)

(5) 1OYR $4 / 2$ (dark grayish brown with small pea gravels)

(6) 1OYR $5 / 3$ (brown sterile with limestone gravels)

Figure 5-2. Profile of North Wall of Trench 1 and South Wall of extension under building. 
Table 5-5. Proveniences from Trench 1 Excavations and Analysis Units Defined by CAR

\begin{tabular}{|c|l|c|c|}
\hline Provenience/Unit & \multicolumn{1}{|c|}{ Catalogue Description } & $\begin{array}{c}\text { Analysis } \\
\text { Unit/Level }\end{array}$ & Lot Number \\
\hline SM1-3 & 0-40 cm & II/1 & $1991-018$ \\
\hline SM1-4 & Level 1, above floor & $\mathrm{II} / 1$ & $1991-019$ \\
\hline SM1-7 & Level 1, above floor & $\mathrm{II} / 1$ & $1991-022$ \\
\hline SM1-8 & Level 1 & $\mathrm{II} / 1$ & $1991-023$ \\
\hline SM1-9 & Level 1, floor surface & $\mathrm{III} / 1$ & $1991-024$ \\
\hline SM1-11 & Northwest corner, below sidewalk & $\mathrm{V} / 1$ & $1991-026$ \\
\hline SM1-18 & Level 1, under sidewalk & $\mathrm{V} / 1$ & $1991-032$ \\
\hline SM1-2 & 0-60 cm, southwest corner & $\mathrm{I} / 1-2$ & $1991-017$ \\
\hline SM1-12 & Levels 1 \&2, east of sidewalk, mixed & $\mathrm{VII} / 1-2$ & $1991-027$ \\
\hline SM1-24 & ateanup, below gravel level & $\mathrm{VII} / 1-2$ & $1991-038$ \\
\hline SM1-25 & at pier & $\mathrm{VII} / 1-2$ & $1991-039$ \\
\hline SM1-26 & at pier & $\mathrm{VII} / 1-2$ & $1991-040$ \\
\hline SM1-27 & at pier, under building & $\mathrm{VII} / 1-2$ & $1991-041$ \\
\hline SM1-28 & under building & $\mathrm{VII} / 1-2$ & $1991-042$ \\
\hline SM1-29 & under building & $\mathrm{VII} / 1-2$ & $1991-043$ \\
\hline SM1-10 & Level 1, trench fill below floor & $\mathrm{IV} / 2$ & $1991-025$ \\
\hline SM1-5 & below floor & $\mathrm{IV} / 2$ & $1991-020$ \\
\hline SM1-6 & below floor & $\mathrm{IV} / 2$ & $1991-021$ \\
\hline SM1-13 & Level 2, fill from under sidewalk & $\mathrm{VI} / 2$ & $1991-028$ \\
\hline SM1-14 & Level 2, fill from under sidewalk & $\mathrm{VI} / 2$ & $1991-029$ \\
\hline SM1-15 & Level 2, fill from under sidewalk & $\mathrm{VI} / 2$ & $1991-030$ \\
\hline SM1-16 & Level 2, fill from under sidewalk & $\mathrm{VI} / 2$ & $1991-031$ \\
\hline SM1-17 & Level 2, fill from under sidewalk & $\mathrm{VI} / 2$ & no artifacts in database \\
\hline SM1-19 & Level 2, below sidewalk & $\mathrm{VI} / 2$ & $1991-033$ \\
\hline SM1-20 & Level 2, below sidewalk & $\mathrm{VI} / 2$ & $1991-034$ \\
\hline SM1-21 & Level 2, below sidewalk & $\mathrm{VI} / 2$ & $1991-035$ \\
\hline SM1-22 & Level 2, below sidewalk & $\mathrm{VI} / 2$ & $1991-036$ \\
\hline SM1-23 & Level 2, below sidewalk & $\mathrm{VI} / 2$ & $1991-037$ \\
\hline & & & \\
\hline & & \\
\hline & & \\
\hline & & \\
\hline & & \\
\hline
\end{tabular}

determined cross-cut these two and were therefore defined as a mix of Levels 1 and 2.

The single largest artifact category recovered during the trench excavations consists of flat and miscellaneous glass combined $(n=898)$, followed by faunal remains $(n=843$; Table 5-6) and nails of all kinds ( $\mathrm{n}=474)$. English stoneware ceramics $(\mathrm{n}=277)$ are also common. Colonial ceramics, when considered in combination are also relatively common $(\mathrm{n}=94)$ while Native American sherds are less frequent $(n=16)$. Lithic tools and cores are infrequent and only one gunflint has been recovered. The quantity of both cut and wire nails is largest in the deepest levels.

The largest number of artifacts recovered came from Analysis Unit VI $(n=1714)$. The next largest number came from Analysis Unit II $(n=491)$, the third largest number of artifacts came from Analysis Unit IV ( $\mathrm{n}=345)$. The differences in the counts may relate either to variability in the volume of matrix excavated or the method of artifact recovery (i.e., screen or not screen) or both.

Sixty-seven percent $(\mathrm{n}=1985)$ of the artifacts recovered from Trench 1 could be assigned to a broad temporal affiliation (Table 5-7). The majority $(\mathrm{n}=1847,93 \%)$ consist of $19^{\text {th }}$ century artifacts, with colonial period materials constituting only $6.3 \%(\mathrm{n}=125)$ of the sample. Considering the vertical distribution of the colonial artifacts, Level 1 had 18 (14\%); mixed Levels 1 and 2 had 17 (14\%); Level 2 had 90 (72\%) specimens. The distribution of the $19^{\text {th }}$ century artifacts appear as follows: Level 1 had 285 (15\%); Levels 1 and 2 had 186 (10\%); Level 2 had 1376 (74\%). This pattern indicates that while colonial period artifacts tend to be more common in the deeper proveniences, these deeper strata are relatively 
Table 5-6. Artifacts Recovered from Trench 1 by Analysis Unit

\begin{tabular}{|c|c|c|c|c|c|c|c|c|c|}
\hline \multirow[b]{2}{*}{ CLASS } & \multirow[b]{2}{*}{ Data } & \multicolumn{7}{|c|}{ Analysis Unit } & \multirow[b]{2}{*}{$\begin{array}{c}\text { Grand } \\
\text { Total } \\
\end{array}$} \\
\hline & & I & II & III & IV & $\mathrm{V}$ & VI & VII & \\
\hline Activity: Toy & COUNT & 1 & 1 & & & & & & 2 \\
\hline Activity: Writing & COUNT & & 1 & & & & & & 1 \\
\hline Bead & COUNT & & 1 & & & & & & 1 \\
\hline \multirow{2}{*}{ Bone } & COUNT & 6 & 250 & 7 & 215 & 4 & 279 & 82 & 843 \\
\hline & WEIGHT $(\mathrm{g})$ & 18.6 & 1012.5 & 16.7 & 669.5 & 7.72 & 1137.43 & 305.1 & 3167.55 \\
\hline Bone tool & COUNT & & & & 1 & & & & 1 \\
\hline Brick & COUNT & 2 & 8 & 1 & 9 & 1 & 8 & 2 & 31 \\
\hline Brick/tile & COUNT & & & & & & & 2 & 2 \\
\hline Burned Rock & COUNT & & 2 & & & & 5 & 1 & 8 \\
\hline Button & COUNT & & & & & & 1 & 1 & 2 \\
\hline Cartridge Casing & COUNT & & & & & & 5 & & 5 \\
\hline Ceramic Figurine & COUNT & & & 1 & & & & & 1 \\
\hline Chinese Ceramic: Porcelain & COUNT & & & & & & & 1 & 1 \\
\hline Clinker & COUNT & & 1 & & & & & & 1 \\
\hline Colonial Ceramic: Lead Glazed & COUNT & & 2 & 6 & 3 & & 16 & 5 & 32 \\
\hline Colonial Ceramic: Tin Glazed & COUNT & 1 & 1 & 1 & 9 & & 1 & 1 & 14 \\
\hline Colonial Ceramic: Unglazed & COUNT & 2 & 2 & 3 & 26 & & 11 & 4 & 48 \\
\hline Concrete/cement & COUNT & & & & & & 1 & & 1 \\
\hline Construction Fastener & COUNT & & & & & & & 1 & 1 \\
\hline Core & COUNT & & & & & & 1 & & 1 \\
\hline Cut Nail & COUNT & 8 & 17 & 6 & 5 & 5 & 34 & 12 & 87 \\
\hline Debitage & COUNT & 4 & 6 & & 1 & & 10 & 9 & 30 \\
\hline English Ceramic: Porcelain & COUNT & 2 & 3 & & & & & & 5 \\
\hline English Ceramic: Stoneware & COUNT & & 5 & & 3 & 2 & 262 & 5 & 277 \\
\hline English Ceramic: White Earthenware & COUNT & & 4 & & 2 & 3 & 18 & 9 & 36 \\
\hline Flat Glass & COUNT & 7 & 9 & & 3 & 8 & 20 & 3 & 50 \\
\hline Glass & COUNT & 18 & 59 & 9 & 6 & 11 & 732 & 13 & 848 \\
\hline Gunflint & COUNT & & & & & & & 1 & 1 \\
\hline Lithic Tool & COUNT & & & & 3 & 2 & 4 & 2 & 11 \\
\hline Metal & COUNT & & 4 & & & 2 & 46 & 15 & 67 \\
\hline Metal Fastener & COUNT & & & & 4 & & 15 & 5 & 24 \\
\hline \multirow{2}{*}{ Metal Scrap } & COUNT & & & & & & 1 & & 1 \\
\hline & WEIGHT (g) & & & & & & 131.5 & & 131.5 \\
\hline Metal: Lead & COUNT & & & & 1 & & & & 1 \\
\hline Mortar & COUNT & 1 & 8 & & & & 1 & & 10 \\
\hline \multirow{2}{*}{ Mussel Shell Fragment } & COUNT & & 2 & 1 & 1 & & & & 4 \\
\hline & WEIGHT $(\mathrm{g})$ & & 1.9 & 0.04 & 0.2 & & & & 2.14 \\
\hline \multirow{2}{*}{ Mussel Shell Umbo } & COUNT & & & & & & 1 & 1 & 2 \\
\hline & WEIGHT (g) & & & & & & 3.9 & 1.44 & 5.34 \\
\hline Nail & COUNT & & 61 & & 23 & 20 & 112 & 40 & 256 \\
\hline Native American Ceramic & COUNT & & & 1 & 2 & & 12 & 1 & 16 \\
\hline Organic & COUNT & & & & & & & 1 & 1 \\
\hline
\end{tabular}


Table 5-6. Continued...

\begin{tabular}{|c|c|c|c|c|c|c|c|c|c|}
\hline \multirow[b]{2}{*}{ CLASS } & \multirow[b]{2}{*}{ Data } & \multicolumn{7}{|c|}{ Analysis Unit } & \multirow[b]{2}{*}{$\begin{array}{c}\text { Grand } \\
\text { Total } \\
\end{array}$} \\
\hline & & I & II & III & IV & $\mathrm{V}$ & VI & VII & \\
\hline Other Ceramic: Insulator & COUNT & & 1 & & & & & & 1 \\
\hline Other Ceramic: Unglazed & COUNT & & 2 & & & & & & 2 \\
\hline Other Rock & COUNT & & & & & & 7 & & 7 \\
\hline Paver & COUNT & & 3 & & & & 9 & & 12 \\
\hline Personal: Jewelry & COUNT & & & & 1 & & & & 1 \\
\hline Plaster & COUNT & & 1 & & 2 & & 0 & & 3 \\
\hline \multirow{2}{*}{ Snail Shell } & COUNT & & & & 1 & & 2 & 1 & 4 \\
\hline & WEIGHT $(\mathrm{g})$ & & & & 0.3 & & 0.8 & 0.62 & 1.72 \\
\hline Tack Metal & COUNT & & & & & & 2 & 4 & 6 \\
\hline \multirow{2}{*}{ Unidentified Metal } & COUNT & 1 & 7 & 1 & 10 & & 52 & 11 & 82 \\
\hline & WEIGHT $(\mathrm{g})$ & 2.6 & 52.4 & 3.6 & 54.5 & & 1999.68 & 271.09 & 2383.87 \\
\hline Wire Nail & COUNT & & 30 & & 14 & 6 & 46 & 35 & 131 \\
\hline Total Sum of COUNT & & 53 & 491 & 37 & 345 & 64 & 1714 & 268 & 2972 \\
\hline
\end{tabular}

Table 5-7. Breakdown of Trench 1 Artifacts by Temporal Affiliation

\begin{tabular}{|l|c|c|c|c|}
\hline \multirow{2}{*}{ AU/Level } & \multicolumn{3}{|c|}{ Period } & \\
\cline { 2 - 5 } & $\begin{array}{c}19 \text { th } \\
\text { century }\end{array}$ & Colonial & Modern & $\begin{array}{c}\text { Grand } \\
\text { Total }\end{array}$ \\
\hline Trench 1-V/1 & 57 & 2 & & 59 \\
\hline Trench 1-II/1 & 212 & 5 & 3 & 220 \\
\hline Trench 1-III/1 & 16 & 11 & & 27 \\
\hline Trench 1-I/1-2 & 41 & 3 & & 44 \\
\hline Trench 1-VII/1-2 & 145 & 14 & 10 & 169 \\
\hline Trench 1-IV/2 & 62 & 44 & & 106 \\
\hline Trench 1-VI/2 & 1314 & 46 & & 1360 \\
\hline Total COUNT & 1847 & 125 & 13 & 1985 \\
\hline
\end{tabular}

disturbed given the high percentages of $19^{\text {th }}$ century materials also present in Level 2.

No indication appears in the notes or the catalog as to the depth of the levels. Since there are only two levels recorded, it seems likely that they would have been more than 18 inches deep. Comparing the profile notes with the artifact numbers suggests that Level 1 was ca. $2 \mathrm{ft}$ deep and Level 2 may have been ca. 2.5 feet deep. However, this does not explain how Level 2 had such a large number of $19^{\text {th }}$ century artifacts.

\section{Test Pit 1}

To investigate in greater detail the nature of the deposits found well under the Sales Museum, a $2 \mathrm{ft}$. by $4 \mathrm{ft}$. test pit (Test
Pit Number One) was hand-excavated approximately 7 feet east of the end of Trench 1. As far as we can determine, one provenience unit, SM1-30 can be assigned to this excavation. The catalog lists it as consisting of concentrated residue from 20 gallons of matrix. However, no list of individual artifacts contained within this cluster is available. Briggs (1993:15) states that the deposits encountered beneath the museum consisted entirely of mixed construction debris.

\section{Trench 2}

Trench 2 was positioned to the west-northwest of the Sales Museum (Figure 4-1). It was three feet wide and dug with a backhoe. It also began at the WPA wall on the west side of the ASM building, passed just under the northwest corner of the Museum, and continued to the NE for approximately 55 feet. At its north end, it joined a 25 foot segment that was oriented E-W. Three distinct segments of the north wall of Trench 2 have been profiled. They include a 30-foot segment beginning at the southern end of the trench, a 10-foot segment at its northern end, and the entire 25-foot north wall of the east-west extension of the trench.

The southwestern most 18 inches of the trench was excavated to a depth of three feet (Figure 5-3). Over the next five feet, the excavations extended to a depth of 5.5-feet. This portion of the trench has vertical walls and a flat bottom suggesting that it was excavated by hand using hand-tools. From six to 17.5 feet from the southwest end of the trench, the bottom of the excavation is at four feet below surface. From roughly 17.5 to 18.5 feet, a distance of one foot, the depth of excavation 

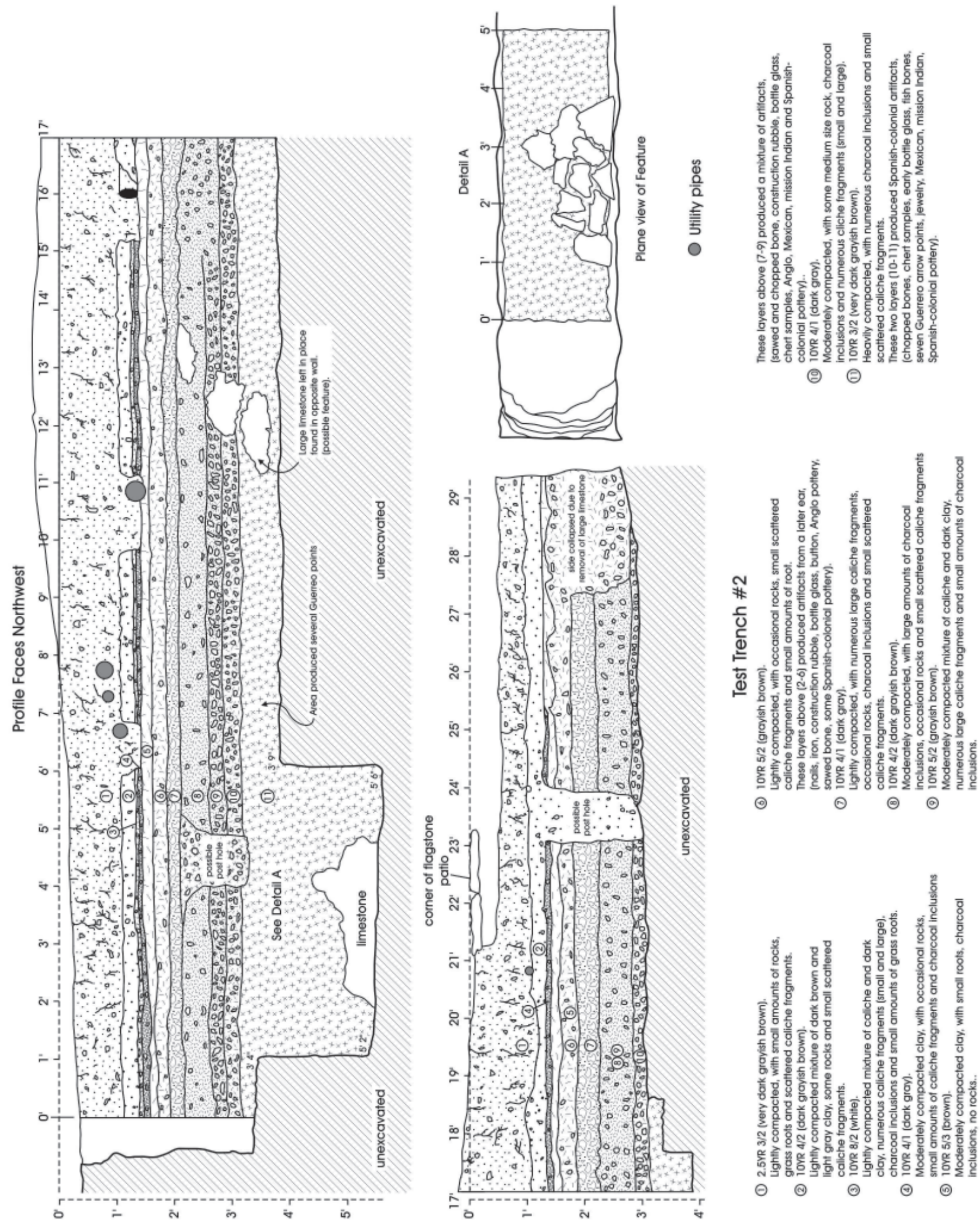

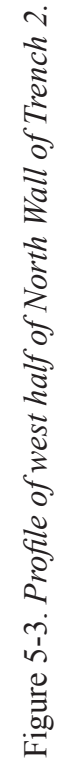


becomes six inches less shallow and from approximately 18.5 to 29.5 feet, the depth of the excavations extends to only three feet below surface.

No profile exists of the next 15 feet of trench wall, but the northern most 11.5 feet have been profiled. The southwestern 3.5-feet of the trench extended to only one foot below surface (Figure 5-4). However, the next eight feet was excavated to a depth of approximately 4.5 -feet.

The north wall of the east-west extension of Trench 2 was profiled. The profile measures 24 feet and extends from under the western sidewalk to the edge of the eastern sidewalk north of the Sales Museum (Figure 5-5). The western end of the trench has the rounded bottom characteristic of backhoe excavated trenches. The bottom of the trench is relatively uneven and the trench appears to have been excavated to a depth of six feet.

Eleven strata have been identified in the north wall of the southwestern portion of Trench 2 (Figure 5-3). The majority continue along the entire length of the profile with the exception of where they are cross-cut by later intrusive pits such as utility trenches for pipes and possible post holes. Two possible post holes are identified on the profile. They originate from different surfaces but both seem to terminate in Layer 10 at approximately 3.5 feet below the surface. The post holes appear to have a maximum diameter of 10-12 inches and have relatively flat bottoms, a characteristic that is more common to trenches rather than post holes. According to the profiles and based on Briggs' discussion (1993:16) two other features may have been exposed in the southwestern portion of the trench. Both features consist of alignments or clusters of limestone cobbles. Briggs (1993:16) interprets these limestone clusters/alignments as "...wall-like and foundation-like features which are certainly linked to the early building phases of the Mission, structures which existed and were razed...." The deepest of the features was exposed at a depth of approximately 4.5 feet and continues below the base of the excavation (Figure 5-3). It is overlain by Stratum 11 which is a heavily compacted layer with charcoal inclusions and Spanish colonial artifacts. The surface upon which the feature sits was not uncovered. Briggs speculates that "The discovery of a stone feature deep in the bottom of Trench Two which cannot be directly affiliated with the Spanish Colonial period, but which is associated with a number of chert (flint) flakes,..." may be the remnants of Mission San Francisco Xavier de Najera (1993:16). Of course, this investigation recovered far too little information to explore this speculation in a meaningful way.
The shorter of the profiles from Trench 2 only identifies nine strata. Stratum 8 overlies a rectangular limestone feature that cuts through Stratum 9. The feature has straight edges, a ninety degree corner and measures at least four feet in length. The top of the feature is at roughly 3.5 -feet below surface and the feature continues to and likely extends beyond the bottom of the excavation/trench. Both of these strata contained Spanish colonial materials. As in the previous instance, the surface upon which the feature sits was not uncovered.

One feature is identified within the east-west extension of Trench 1. This feature consists of a highly compact layer (Layer 8) of clay and river gravels that is roughly six inches thick and extends the entire length of the profile. The top of the layer is buried at approximately two feet below the surface. Briggs (Figure 5-4) suggests that this stratum may represent a floor prepared by the U.S. Army during its occupation of the site. Given that it is found at the same depth and has similar characteristics, Layer 7 in the shorter segment of Trench 2 may be the same as is Layer 8 in the east-west extension. It may also be the same as Layer 7 in the longer of the Trench 2 profiles although no information supporting this speculation is available beyond the equivalent depth of the layer and its similarity in thickness.

Based on the notations present on the trench profiles, the 29-foot section at the southwest end of this trench yielded primarily English pottery and an abundance of other $19^{\text {th }}$ century and later artifacts in Layers 2-6 (Figure 5-3). Layers $7-9$ produced a mixture of $19^{\text {th }}$ century and Colonial period materials and in contrast the two deepest layers (10-11) contributed mainly Spanish Colonial materials. It is possible that landscaping or other impacts have removed the layers containing primarily $19^{\text {th }}$ century and later materials in the eastern half (north of pipes) of Trench 2. According to Briggs (Figure 5-4), Layer 5 contains the mixture of $19^{\text {th }}$ century and Colonial period materials and Layers 7-9 contain mainly Colonial period artifacts. The upper depositional zone containing primarily $19^{\text {th }}$ century and later artifacts is also absent in the east-west extension of Trench 2 (Figure 5-5). Mixed $19^{\text {th }}$ century and colonial materials are present in Layer 9 and colonial materials are found in Layers 10 and 11.

Based on the catalog provided in Briggs (1993), it has been determined that 45 proveniences represent or contain materials recovered from the western half of Trench 2 . These proveniences, their catalog descriptions and the analysis units and levels they have been assigned to are presented in Table $5-8$. The 45 proveniences were grouped into seven analysis units. The analysis units in turn could be grouped into four vertical strata, Levels 1 thru 4. Careful analysis of field notes available and the catalog allowed the determination of the 


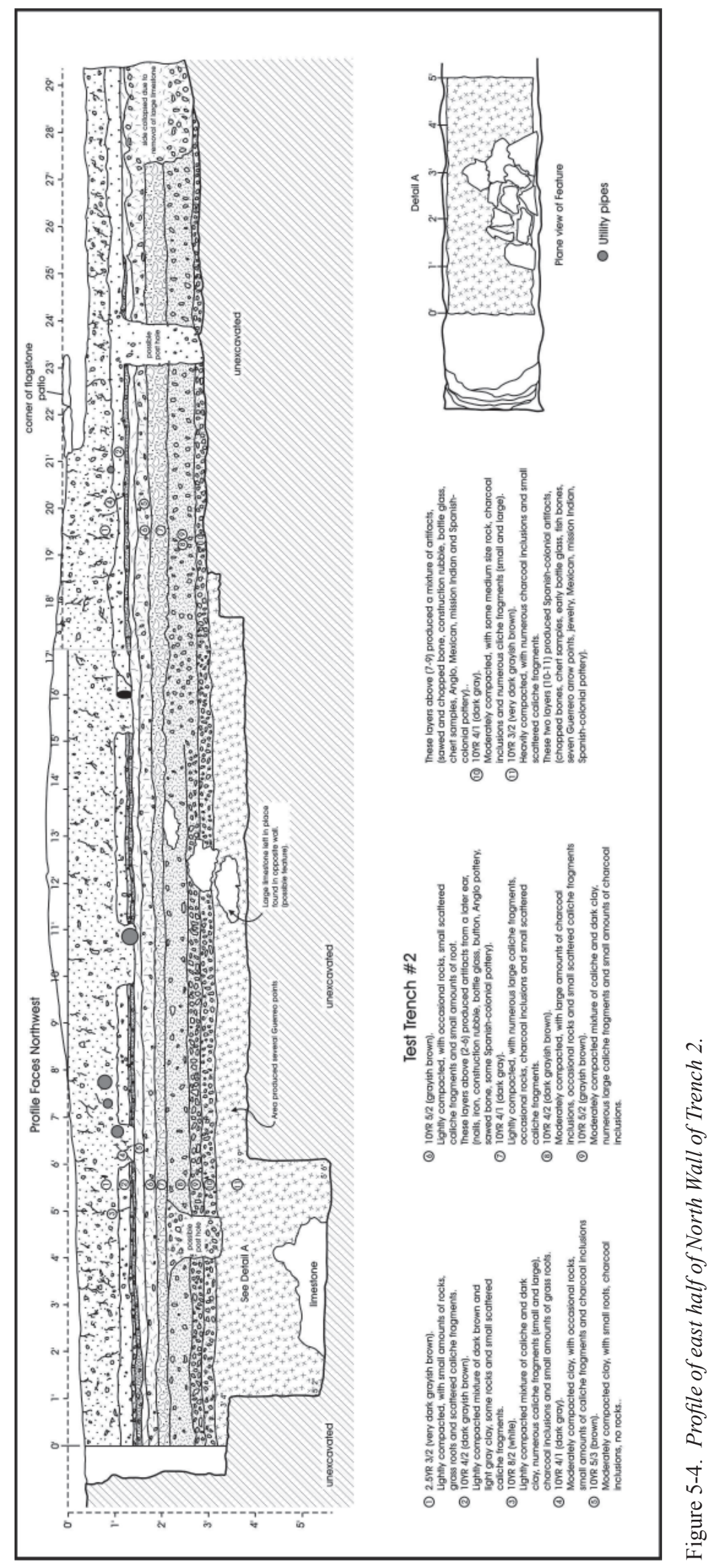



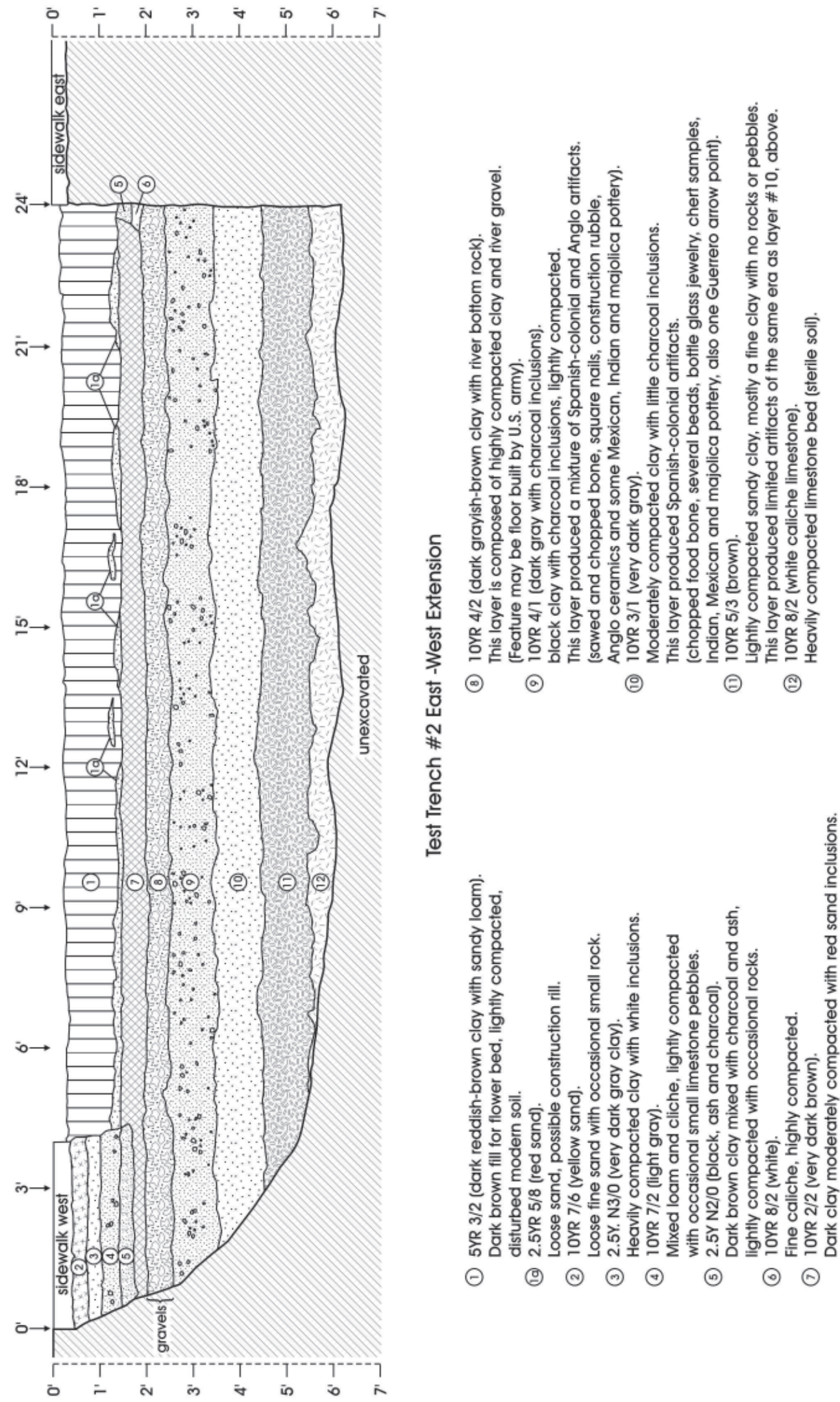

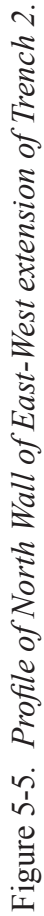


Table 5-8. Proveniences from Western Half of Trench 2 Excavations and Analysis Units Defined by CAR

\begin{tabular}{|c|l|c|c|}
\hline Provenience/Unit & \multicolumn{1}{|c|}{ Catalogue Description } & $\begin{array}{c}\text { Analysis } \\
\text { Unit/Level }\end{array}$ & Lot Number \\
\hline SM2-8 & Levels 1 and 2 & $\mathrm{I} / 1$ & $1991-063$ \\
\hline SM2-1 & Level 1 & $\mathrm{II} / 1$ & $1991-056$ \\
\hline SM2-2 & Level 1 & $\mathrm{II} / 1$ & $1991-057$ \\
\hline SM2-9 & North end of middle zone & $\mathrm{II} / 1$ & $1991-064$ \\
\hline SM2-10 thru SM2-21 & Level 2, black dirt & $\mathrm{IV} / 2$ & $1991-065$ thru 1991-76 \\
\hline SM2-22 thru SM2-26 & Level 2 & $\mathrm{IV} / 2$ & $1991-077$ thru 1991-081 \\
\hline SM2-27 & Level 2, below gravel & $\mathrm{IV} / 2$ & $1991-082$ \\
\hline SM2-48 & Level 2, south of sidewalk, corn level & $\mathrm{IV} / 2$ & $1991-104$ \\
\hline SM2-49 & Level 2, middle of trench & $\mathrm{IV} / 2$ & $1991-105$ \\
\hline SM2-98 & southwest wall, 31.5 in., & $\mathrm{IV} / 2$ & $1991-154$ \\
\hline SM2-97 & Level 3, middle, stone feature & $\mathrm{V} / 3$ & $1991-153$ \\
\hline SM2-50 thru SM2-59 & Level 3 & $\mathrm{V} / 3$ & $1991-106$ thru 1991-115 \\
\hline SM2-63 & Level 3, middle of trench below feature & $\mathrm{V} / 3$ & $1991-019$ \\
\hline SM2-64 thru SM2-66 & Level 3, middle of trench, 36 below surface & $\mathrm{V} / 3$ & $1991-120$ thru 1991-122 \\
\hline SM2-68 & Level 3, south of pipes, 85-95 cm below floor & $\mathrm{V} / 3$ & $1991-124$ \\
\hline SM2-69 & Level 3, south of pipes, 85-95 cm below surface & $\mathrm{V} / 3$ & $1991-125$ \\
\hline SM2-70 & Level 3, south of pipes, bottom & $\mathrm{V} / 3$ & $1991-126$ \\
\hline SM2-72 & southwest end, 42 in., below surface & $\mathrm{VI} / 4$ & $1991-128$ \\
\hline SM2-73 & southwest end, 48 in., below surface & $\mathrm{VI} / 4$ & $1991-129$ \\
\hline
\end{tabular}

following depths of levels: Level $1,0-50 \mathrm{~cm}$ (0 to $19.5 \mathrm{in})$; Level 2, $50-80 \mathrm{~cm}$ (19.5 to $32 \mathrm{in}$ ); Level 3, $80-100 \mathrm{~cm}$ (32 to $39 \mathrm{in}$ ); and Level 4, $100-130 \mathrm{~cm}$ (39 to $51 \mathrm{in}$ ).

Of the total number of artifacts recovered from this section of the trench ( $\mathrm{n}=7757$; Table 5-9), the faunal remains constitute the largest $(\mathrm{n}=5751)$, followed by glass of all kinds $(\mathrm{n}=638)$. The combined group of Colonial ceramics $(n=303)$ represent one of the largest remaining artifact categories. Native American ceramics (Goliad wares) occur in relatively high numbers $(\mathrm{n}=93)$, while gunflints $(\mathrm{n}=1)$ and lithic tools $(\mathrm{n}=1)$ are infrequent. English ceramics are also infrequent but artifacts made of various metals are relatively frequent.

Comparing the artifact totals from all levels, the largest number of artifacts $(\mathrm{n}=4818)$ was recovered from Level 2 (Analysis Unit IV). Level 3 (Analysis Unit V) produced the next largest number $(\mathrm{n}=2408)$ and Level 1 (Analysis Units I-III) the next largest (504), and only 27 artifacts came from Level 4 (Analysis Unit VI). This distribution of artifacts indicates that the majority of the artifacts recovered from the western portion of Trench 2 come from the middle of the stratigraphic column. Although Level 1 is a thick zone $(50 \mathrm{~cm})$, much of it may be introduced fill for landscaping. In addition, while Level 4 is also relatively thick $(30 \mathrm{~cm})$, excavations reached this depth only in limited areas of the trench.
Forty-three percent $(n=3370)$ of the artifacts recovered from the western half of Trench 2 could be assigned to a broad temporal affiliation (Table 5-10). The majority $(n=2548,76 \%)$ consist of $19^{\text {th }}$ century artifacts, with colonial period materials constituting of $24 \%(n=818)$ of the sample. Considering the vertical distribution of the colonial artifacts, Level 1 had 34 (4\%); Level 2 had 227 (28\%) specimens. Nineteenth century artifacts outnumber colonial specimens in Level $1(n=226)$ and Level $2(\mathrm{n}=1016)$. However, 19 ${ }^{\text {th }}$ century artifacts are infrequent in Levels $3(n=32)$ but common in Level 4 $(\mathrm{n}=1274)$. This pattern indicates that Level 3 and the few artifacts may be relatively unmixed although this does not make much sense in light of the large number of $19^{\text {th }}$ century items in Level 4. These patterns also seem to agree well with the generalized notes regarding the artifact content of layers summarized on the trench profile (Figure 5-3).

Based on the catalog provided in Briggs (1993), it has been determined that 29 proveniences represent or contain materials recovered from the eastern (north of pipes) half of Trench 2. These proveniences, their catalog descriptions and the analysis units and levels they have been assigned to are presented in Table 5-11. The 29 proveniences were grouped into three analysis units. The analysis units in turn could be grouped into three vertical strata, Levels 1 thru 3. Careful analysis of field notes available and the catalog allowed the determination of the following depths of levels: Level 1, 0 
Table 5-9. Artifacts Recovered from the Western Half of Trench 2 by Analysis Unit

\begin{tabular}{|c|c|c|c|c|c|c|c|c|}
\hline \multirow{2}{*}{ CLASS } & \multirow[b]{2}{*}{ Data } & \multicolumn{6}{|c|}{ Analysis Unit } & \multirow[b]{2}{*}{ Grand Total } \\
\hline & & $\mathrm{I}$ & II & III & IV & $\mathrm{V}$ & VI & \\
\hline Activity: Coin & COUNT & & 1 & & & & & 1 \\
\hline Activity: Gaming & COUNT & & & & 2 & & & 2 \\
\hline \multirow{2}{*}{ Bone } & COUNT & & 23 & 162 & 3496 & 2059 & 11 & 5751 \\
\hline & WEIGHT (g) & & 56.5 & 471.7 & 4965.51 & 3576.87 & 9.57 & 9080.15 \\
\hline Bone Tool & COUNT & & & & 2 & & & 2 \\
\hline Brick & COUNT & & & & 1 & 1 & & 2 \\
\hline Burned Rock & COUNT & & & & 7 & & & 7 \\
\hline Button & COUNT & & 5 & & 2 & & & 7 \\
\hline Clay Pipe & COUNT & & & & 1 & & & 1 \\
\hline Colonial Ceramic: Lead Glazed & COUNT & & 4 & 15 & 75 & 31 & & 125 \\
\hline Colonial Ceramic: Mexican Black Luster Glaze & COUNT & & & 2 & & & & 2 \\
\hline Colonial Ceramic: Tin Glazed & COUNT & & 1 & 5 & 45 & 21 & & 72 \\
\hline Colonial Ceramic: Unglazed & COUNT & & & 3 & 59 & 42 & & 104 \\
\hline Core & COUNT & & & & & 3 & & 3 \\
\hline Cut Nail & COUNT & & 74 & 4 & 336 & 3 & & 417 \\
\hline Debitage & COUNT & & 1 & 3 & 23 & 27 & 9 & 63 \\
\hline English Ceramic: Redware & COUNT & & 1 & & & & & 1 \\
\hline English Ceramic: Stoneware & COUNT & & 3 & & & 1 & & 4 \\
\hline English Ceramic: White Earthenware & COUNT & & 4 & 1 & 8 & & & 13 \\
\hline Flat Glass & COUNT & & 8 & 1 & 28 & & & 37 \\
\hline Fossil & COUNT & 1 & & & & & & 1 \\
\hline Glass & COUNT & & 37 & 11 & 552 & & 1 & 601 \\
\hline Gunflint & COUNT & & & 1 & & & & 1 \\
\hline Lead Shot & COUNT & & & & & 30 & & 30 \\
\hline Lithic Tool & COUNT & & & & & 1 & & 1 \\
\hline Metal & COUNT & & 20 & & 2 & 1 & & 23 \\
\hline Metal Fastener & COUNT & & 1 & & 51 & & & 52 \\
\hline Metal: Lead & COUNT & & & & 7 & & & 7 \\
\hline Metal: Tin & COUNT & & & & 4 & & & 4 \\
\hline Mortar & COUNT & & & & 1 & & & 1 \\
\hline \multirow{2}{*}{ Mussel Shell Fragment } & COUNT & & & 1 & 4 & 2 & & 7 \\
\hline & WEIGHT (g) & & & 0.4 & 10.53 & 3.4 & & 14.33 \\
\hline \multirow{2}{*}{ Mussel Shell Umbo } & COUNT & & & & & 3 & & 3 \\
\hline & WEIGHT (g) & & & & & 27.2 & & 27.2 \\
\hline Native American Ceramic & COUNT & & 1 & 3 & 36 & 53 & & 93 \\
\hline Other Ceramic: Terra Cotta & COUNT & & 3 & & & & & 3 \\
\hline Other Organic & COUNT & & & & 1 & & & 1 \\
\hline Other Rock & COUNT & & & & & 9 & & 9 \\
\hline Paver & COUNT & & & & & 1 & & 1 \\
\hline Personal & COUNT & & & & 1 & & & 1 \\
\hline Plaster & COUNT & 7 & & & 1 & 33 & & 41 \\
\hline
\end{tabular}


Table 5-9. Continued...

\begin{tabular}{|c|c|c|c|c|c|c|c|c|}
\hline \multirow{2}{*}{ CLASS } & \multirow[b]{2}{*}{ Data } & \multicolumn{6}{|c|}{ Analysis Unit } & \multirow[b]{2}{*}{\begin{tabular}{|l} 
Grand Total \\
\end{tabular}} \\
\hline & & $\bar{I}$ & II & $\begin{array}{l}\text { III } \\
\end{array}$ & IV & $\mathrm{V}$ & $\mathrm{VI}$ & \\
\hline \multirow{2}{*}{ Snail Shell } & COUNT & & & & 39 & 85 & 6 & 130 \\
\hline & WEIGHT (g) & & & & 2.63 & 9.3 & 2.02 & 13.95 \\
\hline Tack Metal & COUNT & & 1 & & & & & 1 \\
\hline \multirow{2}{*}{ Unidentified Metal } & COUNT & & 47 & & 33 & 2 & & 82 \\
\hline & WEIGHT (g) & & 232.2 & & 165.19 & 32 & & 429.39 \\
\hline Wire Nail & COUNT & & 35 & 14 & 1 & & & 50 \\
\hline Total Sum of COUNT & & 8 & 270 & 226 & 4818 & 2408 & 27 & 7757 \\
\hline
\end{tabular}

Table 5-10. Breakdown of Artifacts from Western Half of Trench 2 by Temporal Affiliation

\begin{tabular}{|c|c|c|c|c|}
\hline \multirow{2}{*}{$\begin{array}{c}\text { AU/ } \\
\text { Level }\end{array}$} & \multicolumn{3}{|c|}{ Period } & \multirow[b]{2}{*}{$\begin{array}{c}\text { Grand } \\
\text { Total }\end{array}$} \\
\hline & $\begin{array}{c}19 \text { th } \\
\text { century }\end{array}$ & Colonial & Modern & \\
\hline $\mathrm{I} / 1$ & & & & 0 \\
\hline $\mathrm{II} / 1$ & 190 & 6 & 4 & 200 \\
\hline III/1 & 36 & 28 & & 64 \\
\hline $\mathrm{IV} / 2$ & 1016 & 227 & & 1243 \\
\hline $\mathrm{V} / 3$ & 32 & 148 & & 180 \\
\hline $\mathrm{VI} / 4$ & 1274 & 409 & & 1683 \\
\hline $\begin{array}{l}\text { Total } \\
\text { COUNT }\end{array}$ & 2548 & 818 & 4 & 3370 \\
\hline
\end{tabular}

Table 5-11. Proveniences from Eastern Half of Trench 2 Excavations and Analysis Units Defined by CAR

\begin{tabular}{|c|c|c|c|}
\hline $\begin{array}{c}\text { Provenience/ } \\
\text { Unit }\end{array}$ & $\begin{array}{l}\text { Catalogue } \\
\text { Description }\end{array}$ & $\begin{array}{l}\text { Analysis } \\
\text { Unit/Level }\end{array}$ & Lot Number \\
\hline $\begin{array}{l}\text { SM2-3 thru } \\
\text { SM2-5 }\end{array}$ & $\begin{array}{l}\text { Level 1, north } \\
\text { of pipes }\end{array}$ & $\mathrm{I} / 1$ & $\begin{array}{c}1991-058 \text { thru } \\
1991-060\end{array}$ \\
\hline SM2-6 & $\begin{array}{l}\text { Level 1, } \\
\text { north of } \\
\text { pipes, below } \\
\text { sidewalk }\end{array}$ & $\mathrm{I} / 1$ & 1991-061 \\
\hline SM2-7 & $\begin{array}{l}\text { Level 1, north } \\
\text { of sidewalk, } \\
3 / 26 / 92\end{array}$ & $\mathrm{I} / 1$ & $1991-062$ \\
\hline $\begin{array}{l}\text { SM2-28 thru } \\
\text { SM2-46 }\end{array}$ & $\begin{array}{l}\text { Level 2, north } \\
\text { of pipes }\end{array}$ & $\mathrm{II} / 2$ & $\begin{array}{c}1991-083 \text { thru } \\
1991-102\end{array}$ \\
\hline SM2-47 & $\begin{array}{l}\text { Level 2, north } \\
\text { of pipes, } \\
\text { below floor }\end{array}$ & $\mathrm{II} / 2$ & 1991-103 \\
\hline $\begin{array}{l}\text { SM2-60 thru } \\
\text { SM2-62 }\end{array}$ & $\begin{array}{l}\text { Level 3, north } \\
\text { of pipes }\end{array}$ & $\mathrm{III} / 3$ & $\begin{array}{c}1991-116 \text { thru } \\
1991-118\end{array}$ \\
\hline
\end{tabular}

$-46 \mathrm{~cm}$ (0 to $18 \mathrm{in})$; Level 2, $46-76 \mathrm{~cm}$ (18 to $36 \mathrm{in})$; and Level 3, $76-106 \mathrm{~cm}$ (36 to $48 \mathrm{in})$.

As it was the case in the other proveniences across the site, the most common artifact recovered was animal bone $(n=8739$; Table 5-12). Faunal remains are most common in the two deepest analysis units. Of the total number of artifacts other than faunal remains $(n=1215)$, Colonial ceramics constitute the largest number $(n=467)$. Of the Colonial wares, the lead glazed ceramic category $(\mathrm{n}=228)$ is the largest, followed by the tin glazed ceramics $(n=160)$. Even unglazed Colonial wares are relatively common $(\mathrm{n}=79)$. All English wares combined represent smaller samples than the unglazed Colonial specimens. Native American Goliad specimens are only slightly less frequent than English White Earthenwares. All nails combined $(\mathrm{n}=206)$, fragments of all kinds of glass $(\mathrm{n}=127)$ and pieces of unidentifiable metal are also relatively common as in all other proveniences. These breakdowns in artifacts suggest that the eastern half of Trench 2 contained a higher proportion of colonial deposits relative to $19^{\text {th }}$ century strata than the western end of the trench.

Level 2 (Analysis Unit II) contained the highest number of artifacts $(n=6700)$ followed by Level 3 (Analysis Unit III; Table 5-12). This pattern of artifact recovery does not necessarily correlate with the relative thickness of these levels and again suggests that while Level 1 contains a greater volume of matrix, some of it may represent fill devoid of artifacts that was brought in and added to the surface of the courtyard.

Only eleven percent ( $\mathrm{n}=1070$ out of 9954) of the large number of artifacts recovered from north of the pipes in this trench could be assigned to relative temporal affiliation (Table 5-13). Of the 512 colonial artifacts recovered, Level 1 contained only $1 \%(\mathrm{n}=7)$, Level 2 had $85 \%(\mathrm{n}=436)$, and Level 3 retained $14 \%(\mathrm{n}=69)$. Of the $55719^{\text {th }}$ century artifacts recovered, Level 1 had 52\%, Level 2 contained $44 \%$ 
Table 5-12. Artifacts Recovered from the Eastern Half of Trench 2 by Analysis Unit

\begin{tabular}{|c|c|c|c|c|c|}
\hline \multirow{2}{*}{ CLASS } & \multirow[b]{2}{*}{ Data } & \multicolumn{3}{|c|}{ Analysis Unit/Level } & \multirow[b]{2}{*}{ Grand Total } \\
\hline & & $\mathrm{I} / 1$ & $\mathrm{II} / 2$ & $\mathrm{III} / 3$ & \\
\hline Activity: Coin & COUNT & & 1 & & 1 \\
\hline Activity: Gaming & COUNT & & 1 & & 1 \\
\hline Bead & COUNT & & 2 & 2 & 4 \\
\hline \multirow{2}{*}{ Bone } & COUNT & 114 & 5954 & 2671 & 8739 \\
\hline & WEIGHT $(\mathrm{g})$ & 277.2 & 7612.64 & 2867.36 & 10757.2 \\
\hline Bone tool & COUNT & & 1 & & 1 \\
\hline Brick & COUNT & 4 & 8 & 23 & 35 \\
\hline Building Material & COUNT & & 1 & & 1 \\
\hline Burned Rock & COUNT & & & 6 & 6 \\
\hline Button & COUNT & & 3 & & 3 \\
\hline Ceramic Figurine & COUNT & & 1 & & 1 \\
\hline Chinese Ceramic: Porcelain & COUNT & & 1 & & 1 \\
\hline Colonial Ceramic: Lead Glazed & COUNT & 4 & 212 & 12 & 228 \\
\hline Colonial Ceramic: Tin Glazed & COUNT & 1 & 142 & 17 & 160 \\
\hline Colonial Ceramic: Unglazed & COUNT & 1 & 45 & 33 & 79 \\
\hline Cut Nail & COUNT & 91 & 36 & & 127 \\
\hline Debitage & COUNT & 1 & 50 & 13 & 64 \\
\hline English Ceramic: Porcelain & COUNT & 2 & 1 & & 3 \\
\hline English Ceramic: Stoneware & COUNT & & 1 & & 1 \\
\hline English Ceramic: White Earthenware & COUNT & 11 & 43 & 1 & 55 \\
\hline Flat Glass & COUNT & 2 & 4 & & 6 \\
\hline Glass & COUNT & 49 & 68 & 4 & 121 \\
\hline Gunflint & COUNT & & 2 & 1 & 3 \\
\hline Lithic Tool & COUNT & & 2 & & 2 \\
\hline \multirow{2}{*}{ Marine Shell } & COUNT & & 3 & & 3 \\
\hline & WEIGHT (g) & & 2.4 & & 2.4 \\
\hline \multirow{2}{*}{ Marine Shell Fragment } & COUNT & & 2 & & 2 \\
\hline & WEIGHT (g) & & 0.3 & & 0.3 \\
\hline Metal & COUNT & 61 & 4 & & 65 \\
\hline Metal Fastener & COUNT & 17 & 5 & & 22 \\
\hline Musket Ball & COUNT & & 1 & & 1 \\
\hline \multirow{2}{*}{ Mussel Shell Fragment } & COUNT & 1 & 16 & 2 & 19 \\
\hline & WEIGHT (g) & 0.2 & 7.03 & 1.6 & 8.83 \\
\hline \multirow{2}{*}{ Mussel Shell Umbo } & COUNT & & 2 & & 2 \\
\hline & WEIGHT (g) & & 17.5 & & 17.5 \\
\hline Nail & COUNT & & 21 & 4 & 25 \\
\hline Native American Ceramic & COUNT & 1 & 27 & 7 & 35 \\
\hline Other Rock & COUNT & & 1 & & 1 \\
\hline Paver & COUNT & & 2 & & 2 \\
\hline Plaster & COUNT & & 4 & & 4 \\
\hline Point & COUNT & & 3 & & 3 \\
\hline \multirow{2}{*}{ Slag } & COUNT & 15 & 1 & 5 & 21 \\
\hline & WEIGHT (g) & 13.5 & 2.3 & 9.7 & 25.5 \\
\hline
\end{tabular}


Table 5-12. Continued...

\begin{tabular}{|l|l|r|r|r|r|}
\hline \multirow{2}{*}{ CLASS } & & \multicolumn{3}{|c|}{ Analysis Unit/Level } & \\
\cline { 2 - 6 } & \multicolumn{1}{|c|}{ Data } & I/1 & II/2 & III/3 & Grand Total \\
\hline \multirow{3}{*}{ Snail shell } & COUNT & & 1 & 3 & 4 \\
\cline { 2 - 6 } & WEIGHT (g) & & 0.1 & 0.21 & 0.31 \\
\hline Tack Metal & COUNT & 5 & & & 5 \\
\hline \multirow{2}{*}{ Unidentified Metal } & COUNT & 16 & 17 & 2 & 35 \\
\cline { 2 - 6 } & WEIGHT (g) & 69.8 & 87.2 & 6.2 & 163.2 \\
\hline Wire Nail & COUNT & 50 & 4 & & 54 \\
\hline Total COUNT & & 448 & 6700 & 2806 & 9954 \\
\hline
\end{tabular}

Table 5-13. Breakdown of Artifacts from Eastern Half of Trench 2 by Temporal Affiliation

\begin{tabular}{|l|c|c|c|c|}
\hline \multirow{2}{*}{ AU/Level } & \multicolumn{3}{|c|}{ Period } & \\
\cline { 2 - 5 } & $\begin{array}{c}\text { 19th } \\
\text { century }\end{array}$ & Colonial & Modern & $\begin{array}{c}\text { Grand } \\
\text { Total }\end{array}$ \\
\hline $\mathrm{I} / 1$ & 289 & 7 & & 296 \\
\hline $\mathrm{II} / 2$ & 245 & 436 & 1 & 682 \\
\hline $\mathrm{III} / 3$ & 23 & 69 & & 92 \\
\hline $\begin{array}{l}\text { Total } \\
\text { COUNT }\end{array}$ & 557 & 512 & 1 & 1070 \\
\hline
\end{tabular}

$(\mathrm{n}=245)$, and Level 3 only $4 \%(\mathrm{n}=23)$. Colonial materials outnumbered $19^{\text {th }}$ century specimens in the two deepest levels.

According to the profile, Level 1 includes Stratum 1 through about $1 / 3$ of Stratum 5 and Level 2 includes $2 / 3$ of Stratum 5 through Stratum 7 and a small slice of Stratum 8 . The latter two, according to the profile notes, produced only colonial artifacts. Since Stratum 5 included both $19^{\text {th }}$ century and Colonial artifacts, the combination of Strata 5 through 7 and a small part of Stratum 8 could have comparatively large amounts of both types of artifacts. Level 3 contained most of Strata 8 and 9, which contained primarily Colonial artifacts, but also produced a few $19^{\text {th }}$ century specimens.

After having completed an assessment of Briggs' catalog (1993) related to the east-west extension of Trench 2, the CAR staff determined that 41 proveniences represent or contain materials recovered from this portion of the trench. These proveniences, their catalog descriptions and the analysis units and levels they have been assigned to are presented in Table 5-14. The 41 proveniences were grouped into three analysis units. The analysis units in turn could be grouped into three vertical strata, Levels 1 thru 3. The review of the available field notes and the catalog allowed the determination of the
Table 5-14. Proveniences from East-West Extension of Trench 2 Excavations and Analysis Units Defined by CAR

\begin{tabular}{|c|l|c|c|}
\hline $\begin{array}{c}\text { Provenience/ } \\
\text { Unit }\end{array}$ & $\begin{array}{c}\text { Catalogue } \\
\text { Description }\end{array}$ & $\begin{array}{c}\text { Analysis } \\
\text { Unit/Level }\end{array}$ & Lot Number \\
\hline $\begin{array}{c}\text { SM3-1 thru } \\
\text { SM3-10 }\end{array}$ & Level 1 & $\mathrm{I} / 1$ & $\begin{array}{c}1991-160 \text { thru } \\
1991-169\end{array}$ \\
\hline $\begin{array}{c}\text { SM3-11 thru } \\
\text { SM3-24 }\end{array}$ & $\begin{array}{l}\text { Level 2, } \\
\text { above gravel }\end{array}$ & $\mathrm{II} / 2$ & $\begin{array}{c}1991-170 \text { thru } \\
1991-183\end{array}$ \\
\hline $\begin{array}{c}\text { SM3-25 thru } \\
\text { SM3-40 }\end{array}$ & $\begin{array}{l}\text { Level 2, } \\
\text { below gravel }\end{array}$ & $\mathrm{II} / 2$ & $\begin{array}{c}1991-184 \text { thru } \\
1991-199\end{array}$ \\
\hline SM3-41 & Level 3 & $\mathrm{III} / 3$ & $1991-200$ \\
\hline
\end{tabular}

following depths of levels: Level 1, 0 to 18 inches; Level 2, 18 to 36 inches; and Level 3, 36 to 54 inches.

As in all other proveniences, the most common artifact recovered was animal bone $(\mathrm{n}=4533$, Table 5-15). Faunal remains are most common in Analysis Units I and II, Levels 1 and 2 of the trench extension. Of the total number of artifacts other than faunal remains $(n=2191)$, Colonial ceramics constitute the largest number $(\mathrm{n}=585)$. Of the Colonial wares, the lead glazed ceramic category $(n=343)$ is the largest, followed by the tin glazed ceramics $(n=201)$. Unglazed Colonial wares are less frequent $(n=33)$. All English wares combined also represent relatively large samples $(n=433)$. The white earthenwares are the most common single category $(n=425)$. Native American Goliad specimens are more common $(n=72)$ than in the proveniences derived from the eastern half of the trench. Fragments of all glass combined $(n=298)$ and pieces of unidentifiable metal $(n=286)$, and all nails combined $(n=215)$ are relatively common. The distribution of cut nails is similar to the wire nails, they are most common in the upper two levels and absent from the deepest level. These breakdowns in artifacts suggest that the east-west extension of Trench 2 contained a relatively mixed collection of colonial and $19^{\text {th }}$ century deposits. 
Table 5-15. Artifacts Recovered from the East-West Extension of Trench 2 by Analysis Unit

\begin{tabular}{|c|c|c|c|c|c|}
\hline \multirow{2}{*}{ CLASS } & \multirow[b]{2}{*}{ Data } & \multicolumn{3}{|c|}{ Analysis Unit/Level } & \multirow[b]{2}{*}{ Grand Total } \\
\hline & & $\mathrm{I} / 1$ & $\mathrm{II} / 2$ & $\mathrm{III} / 3$ & \\
\hline Bead & COUNT & & 1 & & 1 \\
\hline \multirow{2}{*}{ Bone } & COUNT & 61 & 4445 & 27 & 4533 \\
\hline & WEIGHT $(\mathrm{g})$ & 331.8 & 12239.07 & 105.3 & 12676.17 \\
\hline Brick & COUNT & & 7 & & 7 \\
\hline Brick/tile & COUNT & & 1 & & 1 \\
\hline Bullet & COUNT & 1 & & & 1 \\
\hline Burned Rock & COUNT & & 1 & & 1 \\
\hline Button & COUNT & & 1 & & 1 \\
\hline Chinese Ceramic: Porcelain & COUNT & & 1 & & 1 \\
\hline Clay Pipe & COUNT & 1 & & & 1 \\
\hline Colonial Ceramic: Lead Glazed & COUNT & 4 & 339 & & 343 \\
\hline Colonial Ceramic: Redware & COUNT & & 8 & & 8 \\
\hline Colonial Ceramic: Tin Glazed & COUNT & 1 & 199 & 1 & 201 \\
\hline Colonial Ceramic: Unglazed & COUNT & 4 & 28 & 1 & 33 \\
\hline Core & COUNT & & & & 0 \\
\hline Cut Nail & COUNT & 19 & 17 & & 36 \\
\hline Debitage & COUNT & 2 & 51 & 1 & 54 \\
\hline English Ceramic: Porcelain & COUNT & & 1 & & 1 \\
\hline English Ceramic: Semi-Porcelain & COUNT & 1 & & & 1 \\
\hline English Ceramic: Stoneware & COUNT & 6 & & & 6 \\
\hline English Ceramic: White Earthenware & COUNT & 5 & 419 & 1 & 425 \\
\hline Flat Glass & COUNT & 39 & 34 & & 73 \\
\hline Glass & COUNT & 61 & 163 & 1 & 225 \\
\hline Gunflint & COUNT & & 1 & & 1 \\
\hline Lithic Tool & COUNT & & 3 & & 3 \\
\hline \multirow{2}{*}{ Marine Shell Fragment } & COUNT & & 1 & & 1 \\
\hline & WEIGHT (g) & & 0.6 & & 0.6 \\
\hline Metal & COUNT & 11 & 20 & & 31 \\
\hline Metal Fastener & COUNT & 16 & 12 & 1 & 29 \\
\hline Mortar & COUNT & 1 & & & 1 \\
\hline Musket Ball & COUNT & & 1 & & 1 \\
\hline \multirow{2}{*}{ Mussel Shell Fragment } & COUNT & & 33 & & 33 \\
\hline & WEIGHT (g) & & 15.5 & & 15.5 \\
\hline \multirow{2}{*}{ Mussel Shell Umbo } & COUNT & & 1 & & 1 \\
\hline & WEIGHT (g) & & 7.7 & & 7.7 \\
\hline Nail & COUNT & & 98 & 4 & 102 \\
\hline Native American Ceramic & COUNT & & 72 & & 72 \\
\hline Other Ceramic & COUNT & & 3 & & 3 \\
\hline Other Ceramic: Porcelain & COUNT & 1 & & & 1 \\
\hline Other Ceramic: Unglazed & COUNT & & 1 & & 1 \\
\hline Paver & COUNT & 5 & 10 & 1 & 16 \\
\hline Personal & COUNT & & 1 & & 1 \\
\hline Plaster & COUNT & & 1 & & 1 \\
\hline
\end{tabular}


Table 5-15. Continued...

\begin{tabular}{|l|l|c|c|c|c|}
\hline \multirow{2}{*}{ CLASS } & & \multicolumn{3}{c|}{ Analysis Unit/Level } & \\
\cline { 2 - 6 } & \multicolumn{1}{|c|}{ Data } & I/1 & II/2 & III/3 & Grand Total \\
\hline Point & COUNT & & 1 & & 1 \\
\hline Rubber & COUNT & 75 & & & 75 \\
\hline Sewer Pipe & COUNT & 1 & & & 1 \\
\hline \multirow{2}{*}{ Snail shell } & COUNT & & 6 & & 6 \\
\cline { 2 - 6 } & WEIGHT (g) & & 3.1 & & 3.1 \\
\hline Soil Samples & COUNT & & 10 & & 10 \\
\hline Tack Metal & COUNT & & 2 & & 2 \\
\hline Tile & COUNT & & 2 & & 2 \\
\hline \multirow{2}{*}{ Unidentified metal } & COUNT & 61 & 223 & 2 & 286 \\
\hline & WEIGHT (g) & 1074.1 & 1720.32 & 8.27 & 2802.69 \\
\hline Wire Nail & COUNT & 38 & 39 & & 77 \\
\hline Total COUNT & & 414 & 6270 & 40 & 6724 \\
\hline
\end{tabular}

Level 2 (Analysis Unit II) contained the highest number of artifacts $(n=6270)$ followed by Level 1 (Analysis Unit I; Table 5-15). Level 3 (Analysis Unit III) had few artifacts.

Twenty-six percent ( $\mathrm{n}=1750$ out of 6724$)$ of the artifacts recovered from east-west extension of Trench 2 could be assigned to relative temporal affiliation (Table 5-16). Of the 670 colonial artifacts recovered, Level 1 contained only $1 \%$ $(\mathrm{n}=9)$, Level 2 had 98\% ( $\mathrm{n}=659)$, and Level 3 retained less than $1 \%(\mathrm{n}=2)$. Of the $107919^{\text {th }}$ century artifacts recovered, Level 1 had 19\% ( $\mathrm{n}=208)$, Level 2 contained $80 \%(\mathrm{n}=862)$, and Level 3 only $1 \%(n=8)$. Nineteenth century materials outnumbered colonial artifacts in all proveniences and fewer Colonial artifacts were found in Level 3 than $19^{\text {th }}$ century items. This distribution supports the contention that the deposits in this east-west extension of Trench 2 are very mixed. The pattern does not agree with Briggs' notation on the east-west extension profile that Layer 10 contained primarily Spanishcolonial artifacts. Layer 10 is part of Level 3 (36-54 inches) and it is clear that Level three produced small numbers of artifacts (even when the artifacts without temporal affiliation are also considered). The gravel layer (Layer 8) that Briggs

Table 5-16. Breakdown of Artifacts from East-West Extension of Trench 2 by Temporal Affiliation

\begin{tabular}{|l|c|c|c|c|}
\hline & \multicolumn{3}{|c|}{ Period } & \\
\cline { 2 - 5 } AU/Level & 19th century & Colonial & Modern & $\begin{array}{c}\text { Grand } \\
\text { Total }\end{array}$ \\
\hline $\mathrm{I} / 1$ & 208 & 9 & & 217 \\
\hline $\mathrm{II} / 2$ & 862 & 659 & 1 & 1522 \\
\hline $\mathrm{III} / 3$ & 9 & 2 & & 11 \\
\hline $\begin{array}{l}\text { Total } \\
\text { COUNT }\end{array}$ & 1079 & 670 & 1 & 1750 \\
\hline
\end{tabular}

suggested may be part of a flooring episode by the U.S. Army is within Level 2 of the stratigraphy as reconstructed by CAR. Level 2 contains all of Layer 7 and 8 and about half of Layer 9 shown on the trench profile (Figure 5-5). As mentioned earlier, these three Layers contributed the bulk of the artifacts recovered from the trench extension.

\section{Trench 3}

Trench 3 was excavated on the east side of the Museum. It extended diagonally to the northeast from the building to a point near the present location of the acequia, just less than 18 feet in length. Once it reached the base of the wall, a fivefoot segment extended under the building. The north wall of the longer segment and the west wall of the short segment under the building were profiled.

The profile of the north wall of the longest trench segment indicates that the first six feet of the trench closest to the museum building was excavated to a depth of approximately 45 inches. Over the next two feet, the bottom of the trench dips to about six feet (72 inches) below surface.

Fourteen strata are shown on the profile (Figure 5-6). The majority are highly undulating layers with some (i.e., Strata $4,5,7)$ being only $2-3$ inches in thickness, while others (i.e., Stratum 1, 10,12) ranging from 1-2 feet in thickness. The examination of the profiles reveals at least two utilities trenches. The first, approximately five feet from the base of the wall, contains a high pressure water line. The base of the utility trench is at approximately 18 inches below the surface. The second, at about 12 feet from the base of the wall, no longer contains the utility line it originally housed. The base 


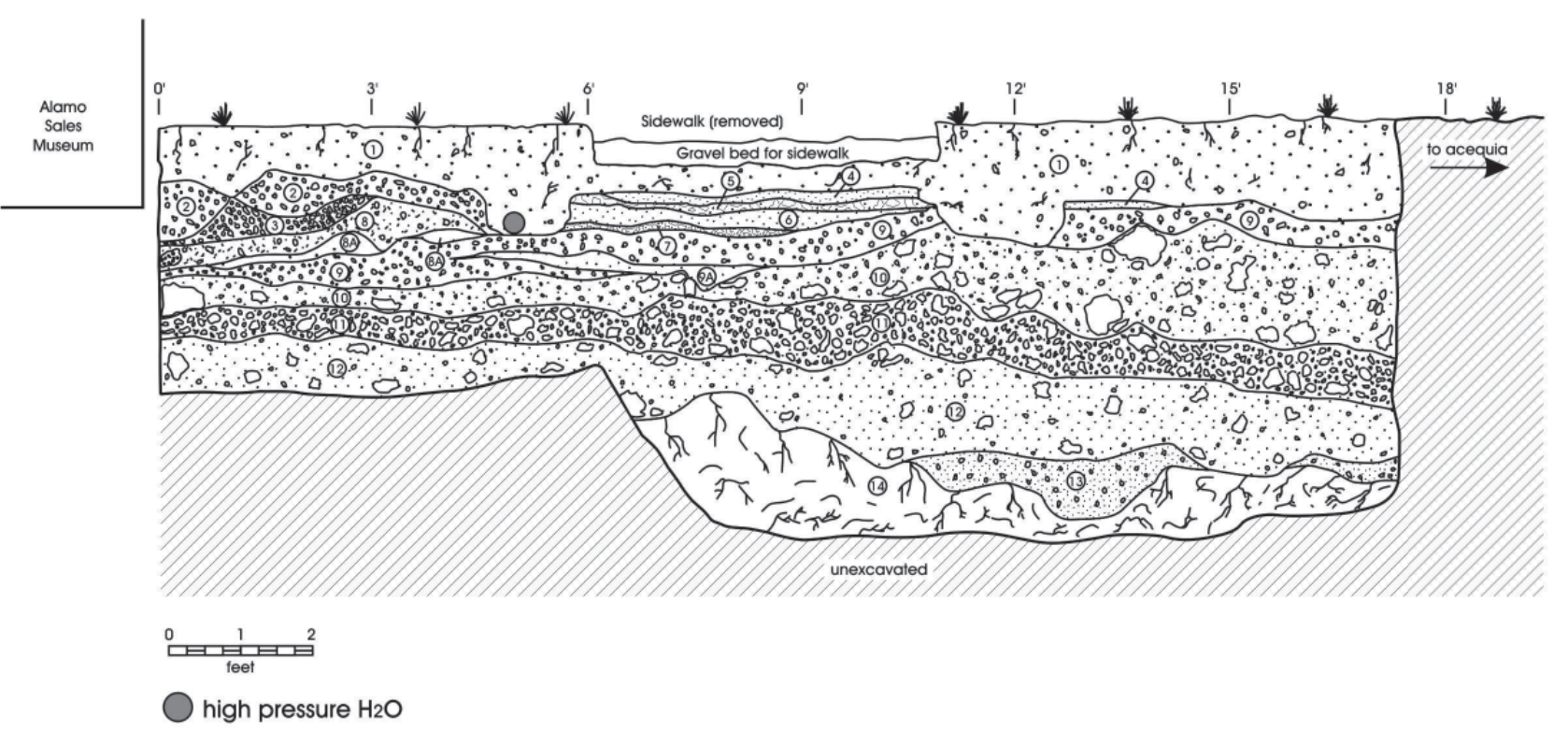

Test Trench 3 East of A.S.M.

(1) 5 YR2.5/1 (black), top soil with high clay content

(2) Construction trench for A.S.M. (high sand content) small gravels/construaction sand and pink gravels from beneath structure, and appears to be a mix of levels 4,5 , and 6

(3) Similar to level 2 construction trench, gravels of various sizes, mix of levels 4,5 , and 6

(4) 10YR $6 / 4$ (light yellowish-brown) thin layer of construction sand and less than 1 "thick in places

(5) (a) $10 Y R 5 / 2$ (grayish-brown)

(b) 10YR $8 / 2$ (white-minor constituent)

(6) (a) $5 Y R \quad 8 / 1$ (white)

(b) $5 Y R \quad 8 / 2$ (pinkish-white)

(7) $10 Y R 5 / 1$ (gray)

(8) 10YR8/3 (very pale brown)

10YR 6/4 (light yellowish-brown)

(80) $15 Y 2.5 / 1$ (black)

(9) $10 Y R 8 / 3$ (very pale brown) mixed with small gravels

(9a) $5 Y R 3 / 1$ (very dark gray with caliche)

(10) 10YR $5 / 1$ (gray) limestone and chert cobbles assorted sizes

(11) 1OYR $3 / 1$ (very dark brown) with gravels

(12) 10 YR $4 / 1$ (dark gray)

(13) 10 YR $4 / 2$ (dark grayish-brown)

(14) 10 Y $8 / 2$ (white with veins of 10 Y $8 / 3$-very pale brown)

\section{Test Trench 3 Notes}

(5) high charcoal content, pane glass

(6) caliche level

(8) square nails, sandy clay

(9) caliche layer

(10) square nails, iron fragments, eggshell

(11) charcoal, wood, squirrel bones

(12) charcoal, burned rock

Test Trench 3 Under A.S.M.

(1) construction gravel light pink

(2) mix caliche and clay (light yellow and light brown)

(3) light yellow caliche

(4) construction gravel and fill

(5) yellow clay with gravel

(6) gray with high ash and charcoal

(7) $10 Y R 4 / 1$ dark gray

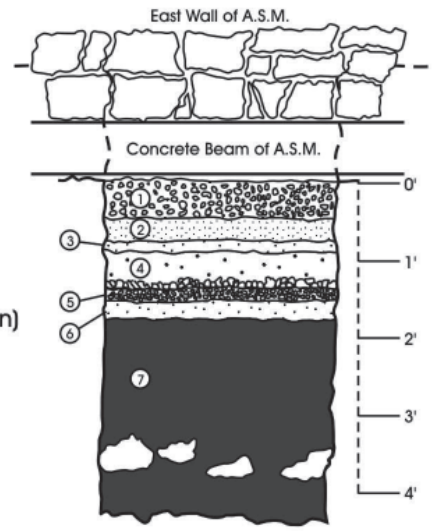

Figure 5-6. Profile of North Wall of Trench 3 and West Wall of extension under building. 
of this trench is at about the same elevation below the surface as that of the first utility trench. Both were excavated from the same level and likely reflect relatively recent landscaping- or plumbing-related improvements.

The profile of the narrow western end of the trench segment that ended under the Museum (Figure 5-6) indicates that the depth of the trench was roughly 4.5 feet. Seven strata are identified in the profile. With the exception of Stratum 8 , the other strata are relatively thin and flat and appear to represent construction debris. Stratum 6 is the only one for which the notation on the profile mentions a charcoal/ash content. Stratum 7 is an approximately 30 -inch thick zone of dark gray matrix that appears to be an alluvial deposit. A layer of stone is present at a depth of about two feet below the top of the zone. The nature of this layer of stone cannot be determined from the available records.

About 1.5 to 2 feet of black topsoil composed the top stratum on either side of a sidewalk that ran parallel to the museum on this side. Between the sidewalk and the museum wall the soil appear to have been disturbed to the two-foot level, either by construction of the building or perhaps by the demolition of nearby commercial buildings previous to the date of the museum construction. Excavation of the trench below the sidewalk disturbance revealed several relatively undisturbed strata of gray soil from this level until it reached sterile white caliche at about five feet in depth. The profile of the portion of Trench 3 that extended under the building appears to be more complex than the profile of the section of Trench 1 that ran beneath the building on the west side.

Regarding the results of the excavations of Trench 3, Briggs (1993:16) notes the following: "Here the excavations proved to be archeologically disappointing, because much of the soil matrix in the trench has been previously disturbed by construction in the area." He attributes the disturbances to two factors, impacts resulting from the construction of the Sales Museum and sidewalk and disturbances resulting from the construction of a branch of the acequia that runs through this area as shown on several historic maps of the Alamo Complex (Figure 2-1).

Since no measurements were given, we have estimated 18inch levels, which appear to correspond with the profile. Level 1, the first 18-inch level, includes Strata 1 through 8 to the west of and under the sidewalk. The next 18 inches, Level 2, includes primarily Strata 9 and 10 and most of 11, which appear to be relatively undisturbed. Level 3 includes a part of Stratum 11 and most of Stratum 12.
Based in large part on the catalog provided by Briggs (1993:194-200), we have identified 12 proveniences that represent or contain materials recovered from Trench 3 . These proveniences, their catalog descriptions and the analysis units and levels they have been assigned to are presented in Table 5-17. The 12 proveniences were grouped into four analysis units. The analysis units in turn could be grouped into three vertical strata, Levels 1 thru 3 (Level 1, $0-46 \mathrm{~cm}$ (0 to 18 in); Level 2, $46-76 \mathrm{~cm}$ (18 to $36 \mathrm{in})$; and Level 3, $76-106$ $\mathrm{cm}$ (36 to $48 \mathrm{in}$ ). Two proveniences, that are part of Analysis Unit IV, could not be assigned to excavation levels because insufficient data is available on their locations.

Table 5-17. Proveniences from Trench 3 Excavations and Analysis Units Defined by CAR

\begin{tabular}{|c|l|c|c|}
\hline $\begin{array}{c}\text { Provenience/ } \\
\text { Unit }\end{array}$ & $\begin{array}{c}\text { Catalogue } \\
\text { Description }\end{array}$ & $\begin{array}{c}\text { Analysis } \\
\text { Unit/Level }\end{array}$ & Lot Number \\
\hline $\begin{array}{c}\text { SM4-1 thru } \\
\text { SM4-4 }\end{array}$ & Level 1 & I/1 & $\begin{array}{c}1991-205 \text { thru } \\
1991-208\end{array}$ \\
\hline $\begin{array}{c}\text { SM4-5 thru } \\
\text { SM4-8 }\end{array}$ & Level 2 & II/2 & $\begin{array}{c}1991-209 \text { thru } \\
1991-212\end{array}$ \\
\hline $\begin{array}{c}\text { SM4-9 thru } \\
\text { SM4-10 }\end{array}$ & Level 3 & III/3 & $\begin{array}{c}1991-213 \text { thru } \\
1991-214\end{array}$ \\
\hline SM4-11 & $\begin{array}{l}\text { under } \\
\text { building }\end{array}$ & $\begin{array}{c}\text { IV/ } \\
\text { unassigned }\end{array}$ & $1991-215$ \\
\hline SM4-12 & $\begin{array}{l}\text { alluvium } \\
\text { 1'10" below } \\
\text { beam }\end{array}$ & $\begin{array}{c}\text { IV/ } \\
\text { unassigned }\end{array}$ & $1991-216$ \\
\hline
\end{tabular}

Animal bones constitute the largest single artifact category recovered from Trench $3(\mathrm{n}=222$; Table 5-18). The only other artifact categories that are reasonably common are unidentified metal fragments $(\mathrm{n}=145)$, all nails combined $(n=149)$ and all glass combined $(n=138)$. Cut and wire nails only occur in Level 1. Colonial ceramics are nearly three times more common than English wares and Native American Goliad specimens are infrequent $(\mathrm{n}=2)$. Level 2 contained the largest number of artifacts $(\mathrm{n}=366)$ although artifacts were also abundant in Level $1(\mathrm{n}=306)$. The density of artifacts decreases in Level 3 compared to the higher levels. However, the decrease may in part also be due to the smaller volume of matrix represented by Level 3 (Figure 5-6).

When studying the location of Trench 3 on the east side of the museum, one can see that it is approximately 80 to 100 feet east of the original outside wall of the mission. Therefore it is not surprising that comparatively few colonial artifacts were present there. The $19^{\text {th }}$ century artifacts from the trench are mostly composed of nails, glass, and metal fragments that seem to represent construction and demolition debris from 
Table 5-18. Artifacts Recovered from Trench 3 by Analysis Unit

\begin{tabular}{|c|c|c|c|c|c|c|}
\hline \multirow{2}{*}{ CLASS } & \multirow[b]{2}{*}{ Data } & \multicolumn{4}{|c|}{ Analysis Unit } & \multirow[b]{2}{*}{ Grand Total } \\
\hline & & I & II & III & IV & \\
\hline Activity: Toy & COUNT & & & 1 & & 1 \\
\hline \multirow{2}{*}{ Bone } & COUNT & 84 & 112 & 14 & 12 & 222 \\
\hline & \begin{tabular}{|l|} 
WEIGHT $(\mathrm{g})$ \\
\end{tabular} & 1174.55 & 432.41 & 56.8 & 92.3 & 1756.06 \\
\hline Brick & COUNT & & 2 & & & 2 \\
\hline \multirow{2}{*}{ Burned Rock } & COUNT & & 3 & 3 & & 6 \\
\hline & WEIGHT $(\mathrm{g})$ & & 0 & & & 0 \\
\hline Button & COUNT & 1 & 1 & & & 2 \\
\hline Cartridge & COUNT & 1 & & & & 1 \\
\hline Colonial Ceramic: Lead Glazed & COUNT & & 2 & 3 & & 5 \\
\hline Colonial Ceramic: Redware & COUNT & & 3 & & & 3 \\
\hline Colonial Ceramic: Tin Glazed & COUNT & & 2 & 1 & 3 & 6 \\
\hline Colonial Ceramic: Unglazed & COUNT & 4 & 8 & & & 12 \\
\hline Core & COUNT & 2 & & & & 2 \\
\hline Cut Nail & COUNT & 10 & & & & 10 \\
\hline Debitage & COUNT & 3 & 3 & & 3 & 9 \\
\hline English Ceramic: Stoneware & COUNT & 5 & & 1 & & 6 \\
\hline English Ceramic: White Earthenware & COUNT & 1 & 3 & & & 4 \\
\hline Flat Glass & COUNT & 10 & 3 & & & 13 \\
\hline Glass & COUNT & 96 & 24 & 2 & 3 & 125 \\
\hline Lithic Tool & COUNT & & & 1 & & 1 \\
\hline Metal & COUNT & 5 & & & 1 & 6 \\
\hline Metal Fastener & COUNT & 3 & 3 & & & 6 \\
\hline \multirow{2}{*}{ Mussel Shell Fragment } & COUNT & & 2 & & 3 & 5 \\
\hline & WEIGHT $(\mathrm{g})$ & & 3.4 & & 0.6 & 4 \\
\hline Nail & COUNT & 53 & 50 & 23 & & 126 \\
\hline Native American Ceramic & COUNT & & 2 & & & 2 \\
\hline Other Ceramic: Insulator & COUNT & 1 & & & & 1 \\
\hline Other Ceramic: Porcelain & COUNT & 1 & & & & 1 \\
\hline Other Rock & COUNT & 4 & 5 & & & 9 \\
\hline \multirow{2}{*}{ Snail Shell } & COUNT & 1 & 4 & 5 & & 10 \\
\hline & WEIGHT $(\mathrm{g})$ & 0.1 & 0.5 & 1.5 & & 2.1 \\
\hline \multirow{2}{*}{ Unidentified Metal } & COUNT & 8 & 134 & 3 & & 145 \\
\hline & WEIGHT $(\mathrm{g})$ & 623.4 & 228.75 & 4 & & 856.15 \\
\hline Wire Nail & COUNT & 13 & & & & 13 \\
\hline Total Sum of COUNT & & 306 & 366 & 57 & 25 & 754 \\
\hline
\end{tabular}

the late $19^{\text {th }}$ century commercial buildings that once stood in this area.

Forty-two percent ( $\mathrm{n}=356$ out of 754) of the artifacts recovered were assigned to temporal periods. Relatively few colonial artifacts (31) were recovered from the entire trench (Table 5-19). Of these, 55\% $(\mathrm{n}=17)$ came from Level 2, 16\% $(\mathrm{n}=5)$ from Level 3, and 19\% $(\mathrm{n}=6)$ from Level 1. In contrast, $32519^{\text {th }}$ century artifacts came from the trench. Of these, $63 \%(n=204)$ came from Level 1, 27\% $(n=87)$ from Level 2, and $8 \%(n=27)$ from Level 3. While the bulk of the colonial artifacts from the trench are found in Levels 2-3, the sheer number of $19^{\text {th }}$ century artifacts is higher $(n=114)$ in these levels than of colonial specimens $(n=22)$. This pattern does 
Table 5-19. Breakdown of Artifacts from Trench 3 by Temporal Affiliation

\begin{tabular}{|l|c|c|c|}
\hline \multirow{2}{*}{ AU/Level } & \multicolumn{2}{|c|}{ Period } & \\
\cline { 2 - 4 } & 19th century & Colonial & $\begin{array}{c}\text { Grand } \\
\text { Total }\end{array}$ \\
\hline I/1 & 204 & 6 & 210 \\
\hline II/2 & 87 & 17 & 104 \\
\hline III/3 & 27 & 5 & 32 \\
\hline IV/unassigned & 7 & 3 & 10 \\
\hline Total COUNT & 325 & 31 & 356 \\
\hline
\end{tabular}

support the conclusion that the matrix cut through by this trench was heavily disturbed by previous construction.

A number of other units are shown on Briggs' Figure 4-1 including: (1) shovel probe \# 1 and Shovel probe \# 2; (2) northwest test unit; and (3) southeast test unit. The outcome of these excavations is not reported in great detail.

\section{The Northwest Test Unit}

This unit was a two-meter square located ca. five feet from the north wall of the museum. It was dug to $135 \mathrm{~cm}$ below the surface. The site map (Figure 4-1) indicates that the west wall of this unit was profiled, however, the materials received by CAR from THC did not include this profile. However, two pages of profile descriptions written between September 22 and $23^{\text {rd }}, 1992$ are available. These notes indicate that 15 strata were identified.

The level descriptions provided below are taken from the notations present on the profile description. The first level, 0 to $15 \mathrm{~cm}$, consisted of base for the sidewalk that had stood above it. The base consisted of sand, small rubble and pebbles. The level was troweled but not screened. The second layer consisted of $2.5 \mathrm{~cm}$ of sterile, tan sandy loam. The third layer, $14 \mathrm{~cm}$ thick, consisted of hard, dark brown clay. Level 4, $4 \mathrm{~cm}$ thick, consisted of sandy loam. Level 5, $2.5 \mathrm{~cm}$ thick, consisted of black, ashy soil. Level 6 was a dark ashy layer $3 \mathrm{~cm}$ thick that appeared to have been disturbed. Level 7 , $2.5 \mathrm{~cm}$ thick, appears to have been disturbed. Level 8, 10 $\mathrm{cm}$ thick, consisted of packed caliche and rubble. Level 9, $6.5 \mathrm{~cm}$ thick, was brown, sandy loam with caliche inclusions. Level 10, $4.5 \mathrm{~cm}$ thick, contained dark brown soil with a high content of river gravels. Level 11, $6 \mathrm{~cm}$ thick, was composed of a mixture of sand and caliche with chert gravels. Level $12,4.5 \mathrm{~cm}$ thick, consisted of sandy brown soil with chert cobbles. Level 13, $19 \mathrm{~cm}$ thick, consisted of light gray clay with large limestone cobbles. Level 14, $11 \mathrm{~cm}$ thick, was similar to Level 13 except that the cobbles were larger. Level
$15,30 \mathrm{~cm}$ thick, was composed of brown sandy loam that was described as sterile in the profile notes. The catalog did however list artifacts derived from this level.

The Briggs catalog indicates that artifacts from 12 proveniences are assigned to the northwest test pit (41BX6SM-24). The proveniences include materials from Levels 3-8, and Levels 11-15, and one provenience identified as Feature 5A. Each of the individual levels is considered a separate analysis unit and the materials from Feature 5A could not be assigned to an analysis unit. The feature appears to have been a concentration of cut nails, bottle glass, and white earthenwares in the northeast corner of the $2-\mathrm{x}-2$ meter test pit. It covered an area about $35-\mathrm{x}-43 \mathrm{~cm}$ and was noted at a depth of $35.5 \mathrm{~cm}$ below the surface. The 12 proveniences were assigned to 11 analysis units with corresponding levels.

Of the total number of artifacts recovered $(n=782$; Table 5-20), the largest category consists of all nails combined $(n=175)$, followed by all glass combined $(n=162)$, and unidentified metal $(n=90)$. Colonial ceramics combined outnumber $(n=64)$ English wares $(n=53)$ and Native American-made specimens are relatively few $(n=13)$. The largest number of artifacts came from Level $7(n=241)$, followed by Level $13(n=110)$, and Level $14(n=100)$. One of the interesting patterns in artifact occurrence is that while faunal remains were the largest single artifact category in many of the other excavation units across the site, animal bone is sparse $(n=19)$ in the northwest test pit. It is not possible to establish whether this pattern reflects actual differences in bone discard across the site or is simply a product of bone recovery methods.

Seventy-six percent ( $n=597$ out of 782) of the artifacts were assigned to temporal periods. Of the total number of colonial artifacts $(\mathrm{n}=81$; Table 5-21), Levels 3 through 6 had none, Level 7 had 5\% $(n=4)$, Level 8 had none, Level 11 had $2.5 \%$ $(n=2)$, and Levels 13 and 14 had 67\% $(n=54)$ and 26\% $(n=21)$, respectively. Of the total number of $19^{\text {th }}$ century artifacts (516), Levels 3-5 combined had 17\% $(n=85)$, Levels 6-8 had a combined $65 \%(n=334)$, and the two levels with the bulk of the colonial artifacts (Levels 13 and 14), had a combined total of $13 \%(n=66)$. The pattern indicates that $19^{\text {th }}$ century materials peak in Levels 6-8 while the colonial materials peak in Level 13. Even as such, however, the shear number of colonial specimens is not much higher $(n=75)$ than $19^{\text {th }}$ century materials $(n=66)$ in Levels 13 and 14, suggesting that mixing of the deposits is still a factor even at this depth.

Notations present on Briggs' profile descriptions suggest that cultural materials from Levels 1-10 tend to consist primarily of $19^{\text {th }}$ century specimens. On the other hand, materials from Level 13 tend to be colonial deposits. This impression tends 
Table 5-20. Artifacts Recovered from the Northwest Test Pit

\begin{tabular}{|c|c|c|c|c|c|c|c|c|c|c|c|c|c|}
\hline \multirow[b]{2}{*}{ CLASS } & \multirow[b]{2}{*}{ Data } & \multicolumn{11}{|c|}{ Analysis Unit/Level } & \multirow[b]{2}{*}{$\begin{array}{c}\text { Grand } \\
\text { Total }\end{array}$} \\
\hline & & $\mathrm{I} / 3$ & $\mathrm{II} / 4$ & $\mathrm{III} / 5$ & $\mathrm{IV} / 6$ & $\mathrm{~V} / 7$ & $\mathrm{VI} / 8$ & $\mathrm{VII} / 11$ & $\mathrm{VIII} / 12$ & $\mathrm{IX} / 13$ & $\mathrm{X} / 14$ & $\mathrm{XI} / 15$ & \\
\hline Activity: Toy & COUNT & 1 & & & & & & & & & & & 1 \\
\hline \multirow{2}{*}{ Bone } & COUNT & & & & & & & & & & 19 & & 19 \\
\hline & WEIGHT (g) & & & & & & & & & & 71.7 & & 71.7 \\
\hline Bone tool & COUNT & & & & & & & 2 & & & & & 2 \\
\hline Brick & COUNT & & & & & & & 4 & & & & & 4 \\
\hline Burned Rock & COUNT & & & 3 & & 1 & & 1 & & & 2 & & 7 \\
\hline Cartridge Casing & COUNT & & & & 1 & & & & & & & & 1 \\
\hline Colonial Ceramic: Lead Glazed & COUNT & & & & & & & & & 25 & 12 & & 37 \\
\hline Colonial Ceramic: Tin Glazed & COUNT & & & & & 1 & & & & 13 & 5 & & 19 \\
\hline Colonial Ceramic: Unglazed & COUNT & & & & & 2 & & & & 3 & 3 & & 8 \\
\hline Concrete/cement & COUNT & & & 1 & & & & & & & & & 1 \\
\hline Construction Fastener & COUNT & & & 1 & 1 & & & & & & & & 2 \\
\hline Cut Nail & COUNT & & 8 & 10 & 15 & 44 & & 9 & & & & & 86 \\
\hline Debitage & COUNT & & 5 & 1 & & 7 & & 1 & & 1 & 24 & & 39 \\
\hline English Ceramic: Porcelain & COUNT & & & & 4 & 10 & 1 & & & & & & 15 \\
\hline English Ceramic: Stoneware & COUNT & & & & 4 & 4 & 2 & 5 & & & & & 15 \\
\hline $\begin{array}{l}\text { English Ceramic: White } \\
\text { Earthenware }\end{array}$ & COUNT & & 2 & 1 & 6 & 4 & 2 & & & 6 & 2 & & 23 \\
\hline Flat Glass & COUNT & & 14 & 5 & 2 & 7 & & 1 & & & & & 29 \\
\hline Glass & COUNT & 1 & 14 & 12 & 19 & 70 & 10 & & & 7 & & & 133 \\
\hline Lithic Tool & COUNT & & & & & & & & & 1 & 1 & & 2 \\
\hline \multirow{2}{*}{ Marine Shell Fragment } & COUNT & & & & & & & & & 2 & & & 2 \\
\hline & WEIGHT (g) & & & & & & & & & 2.3 & & & 2.3 \\
\hline Metal & COUNT & & & 1 & 2 & 7 & 4 & & & 1 & & & 15 \\
\hline Metal Fastener & COUNT & & & 1 & 1 & 10 & 2 & 1 & & & & & 15 \\
\hline Metal: Lead & COUNT & & & & 9 & 6 & & & & & & & 15 \\
\hline Mortar & COUNT & & & & & 2 & & & & 4 & & & 6 \\
\hline \multirow{2}{*}{ Mussel Shell Umbo } & COUNT & & 1 & & & & & & & & & & 1 \\
\hline & WEIGHT (g) & & 15 & & & & & & & & & & 14.88 \\
\hline Nail & COUNT & & & & & 12 & 52 & & 14 & & & & 78 \\
\hline Native American Ceramic & COUNT & & & & & 1 & & & & 12 & & & 13 \\
\hline Other Ceramic & COUNT & & & & & 3 & & & & & & & 3 \\
\hline Other Ceramic: Insulator & COUNT & & 1 & 2 & & & & & & & & & 3 \\
\hline Other Rock & COUNT & 1 & & & & 3 & & 1 & & 9 & 14 & & 28 \\
\hline Paver & COUNT & & 6 & & & & 1 & & & 18 & 4 & & 29 \\
\hline Pellet & COUNT & & & & & & 1 & & & & & & 1 \\
\hline Personal & COUNT & & 1 & & & & & & & & & & 1 \\
\hline Plaster & COUNT & & & & & & & & & & 2 & & 2 \\
\hline Sewer Pipe & COUNT & & & & & & 2 & & & & & & 2 \\
\hline Sewer Tile & COUNT & & & & 2 & 3 & & & & & & & 5 \\
\hline
\end{tabular}


Table 5-20. Continued...

\begin{tabular}{|c|c|c|c|c|c|c|c|c|c|c|c|c|c|}
\hline CLASS & Data & $\mathrm{I} / 3$ & $\mathrm{II} / 4$ & $\mathrm{III} / 5$ & $\mathrm{IV} / 6$ & $\mathrm{~V} / 7$ & $\mathrm{VI} / 8$ & $\mathrm{VII} / 11$ & VIII/12 & $\mathrm{IX} / 13$ & $\mathrm{X} / 14$ & $\mathrm{XI} / 15$ & $\begin{array}{c}\text { Grand } \\
\text { Total }\end{array}$ \\
\hline Slag & COUNT & & 2 & 0 & 2 & & & & & & & & 4 \\
\hline \multirow{2}{*}{ Snail Shell } & COUNT & & & & & & & & & 4 & 2 & 6 & 12 \\
\hline & WEIGHT (g) & & & & & & & & & 0.7 & 1.7 & 4.7 & 7.1 \\
\hline Tile & COUNT & 1 & & & & & & & & & & & 1 \\
\hline Unid. Metal Object & COUNT & & & & & 1 & & & & & & & 1 \\
\hline \multirow{2}{*}{ Unidentified Metal } & COUNT & & 7 & 4 & 5 & 37 & 5 & 18 & & 4 & 10 & & 90 \\
\hline & WEIGHT (g) & & 64 & 7 & 48 & 342 & 44 & 263 & & 38.3 & 22.3 & & 829.68 \\
\hline Wire Nail & COUNT & & 3 & 1 & 1 & 6 & & & & & & & 11 \\
\hline Wood & COUNT & & & & & & & 1 & & & & & 1 \\
\hline Total Sum of COUNT & & 4 & 64 & 43 & 74 & 241 & 82 & 44 & 14 & 110 & 100 & 6 & 782 \\
\hline
\end{tabular}

Table 5-21. Breakdown of Artifacts from Northwest Test Pit by Temporal Affiliation

\begin{tabular}{|l|c|c|c|}
\hline \multicolumn{2}{|c|}{ Period } & \\
\hline 3 Level & 19 th century & Colonial & Grand Total \\
\hline 3 & 2 & & 2 \\
\hline 4 & 47 & & 47 \\
\hline 5 & 36 & & 36 \\
\hline 6 & 67 & & 67 \\
\hline 7 & 192 & 4 & 196 \\
\hline 8 & 75 & & 75 \\
\hline 11 & 31 & 2 & 33 \\
\hline 12 & & & 0 \\
\hline 13 & 37 & 54 & 91 \\
\hline 14 & 29 & 21 & 50 \\
\hline 15 & & & 0 \\
\hline Total COUNT & 516 & 81 & 597 \\
\hline
\end{tabular}

to match reasonably well with the results of the artifact distribution analysis.

\section{The Southeast Test Unit}

This unit was an L-shaped excavation wrapped around the southeast corner of the Museum building. It measured $2 \mathrm{~m}$ east to west, $3 \mathrm{~m}$ north to south, and $90 \mathrm{~cm}$ across, and was dug to $93 \mathrm{~cm}$ below the surface. The site map (Figure 4-1) suggests that none of the walls of this unit were profiled. However, the materials received by CAR from THC did include two pages of profile descriptions of the south wall of the unit. In addition, the list of profiles present among the notes available from the project also mentions this profile drawing as the $16^{\text {th }}$ profile from the site. Unfortunately, the drawing of the profile itself could not be located and was not available for this write-up. These notes indicate that seven strata were identified.

The level descriptions provided below are taken from the notations present on the profile description. Level 1, $25 \mathrm{~cm}$ deep, contained dark brown sandy soil with no artifacts. Level 2 was divided into two parts. The first part, $13 \mathrm{~cm}$ thick, was composed of dark brown silty loam containing charcoal. The second part, $10 \mathrm{~cm}$ thick, contained the same soil, but revealed a soil change to tan sandy fill in an area in the southeast corner. Level 3,10 cm thick, contained the same dark brown silty soil containing a considerable amount of charcoal, with an area of tan sandy fill in the southeast corner. Level 4 was also $10 \mathrm{~cm}$ thick. At ca.58 $\mathrm{cm}$ the soil became light brown to gray sandy loam containing limestone cobles. The tan sandy area continued in the southeast corner. Level $5,10 \mathrm{~cm}$ thick, was composed of the same light brown to gray sandy soil with numerous cobbles. Level 6, $10 \mathrm{~cm}$ thick, was composed of the same light brown to gray sandy loam containing several large cobbles and boulders. The bottom of this level is the upper surface of a caliche stratum. Level 7, 10 $\mathrm{cm}$ thick, was caliche over most of the unit. A trench (Feature 1) ca. $30 \mathrm{~cm}$ wide had been cut from west-northwest to eastsoutheast. The thickness of the caliche layer varied from $1 \mathrm{~cm}$ at the southwest part of the unit to $12 \mathrm{~cm}$ near the north end. There were numerous variations in the soil below the caliche, including dark brown silty loam at the west end, light brown to tan sand at the north end, and several pockets of dark, silty or sandy loam throughout the level. Level 8 consisted of a 50 x $50 \mathrm{~cm}$ unit in the northeast corner of the Southeast Unit. It was excavated $20 \mathrm{~cm}$ into the subsoil, which was black clay loam and contained no artifacts.

The Briggs catalog (1998:239) indicates that artifacts from eight proveniences are assigned to the southeast test pit 
(41BX6SM-17 thru SM23; Table 5-22). The proveniences include materials from Levels 2-7, and Feature 1, which the profile notes suggest was encountered in Level 8. The feature appears to have been an intrusive trench filled with the dark sandy loam noted in Level 7. It contained a mix of ten $19^{\text {th }}$ century and colonial artifacts. For the purposes of the analysis, each level was considered its own analysis unit.

Table 5-22. Proveniences from the Southeast Test Pit and Analysis Units Defined by CAR

\begin{tabular}{|c|c|c|c|}
\hline $\begin{array}{c}\text { Provenience/ } \\
\text { Unit }\end{array}$ & $\begin{array}{c}\text { Catalogue } \\
\text { Description }\end{array}$ & $\begin{array}{c}\text { Analysis } \\
\text { Unit/Level }\end{array}$ & Lot Number \\
\hline SM-17 & Level 2 & I/2 & $\begin{array}{c}1991-205 \text { thru } \\
1991-208\end{array}$ \\
\hline SM-18 & Level 3 & $\mathrm{II} / 3$ & $\begin{array}{c}1991-209 \text { thru } \\
1991-212\end{array}$ \\
\hline SM-19 & Level 4 & $\mathrm{III} / 4$ & $\begin{array}{c}1991-213 \text { thru } \\
1991-214\end{array}$ \\
\hline SM-20 & Level 5 & $\mathrm{IV} / 5$ & $1991-215$ \\
\hline SM-21 & Level 6 & $\mathrm{V} / 6$ & $1991-246$ \\
\hline SM-22 & Level 7 & $\mathrm{VI} / 7$ & $\begin{array}{c}\text { no artifacts in } \\
\text { database }\end{array}$ \\
\hline SM-23 & Feature 1 & $\mathrm{VII} / 8$ & $1991-216$ \\
\hline
\end{tabular}

Of the total number of artifacts recovered from this unit $(n=2144$; Table 5-23), the largest category is all glass combined $(\mathrm{n}=1192)$, followed by all nails combined $(\mathrm{n}=265)$, bone $(n=190)$, and unidentified metal $(n=182)$. Wire nails are infrequent $(\mathrm{n}=8)$ and cut nails tend to occur in moderate densities throughout Levels 3-6. Only a combined 49 ceramics are colonial wares and English wares dominate the ceramic collection from this unit $(\mathrm{n}=126)$. Native American wares are infrequent $(\mathrm{n}=5)$. Among the Colonial ceramics unglazed wares are the most common $(\mathrm{n}=28)$ while white earthenwares $(n=38)$ dominate within the English ceramics. The largest number of artifacts came from Level $5(\mathrm{n}=498)$, followed by Level 2 ( $\mathrm{n}=494)$, and Level $3(\mathrm{n}=408)$.

A total of $80.5 \%(\mathrm{n}=1727)$ of the artifacts was assigned to temporal periods. Of these, 19th century artifacts $(n=1670)$ by far outnumber those from the colonial period $(n=56$; Table 5-24). Colonial artifacts are most common in Levels $5(\mathrm{n}=11)$ and $6(\mathrm{n}=27)$, although even there, $19^{\text {th }}$ century specimens well outnumber the colonial items $(n=315$ and $\mathrm{n}=88$, respectively).

There is no obvious stratification between the contents of the levels from top to bottom. This may have been due to the fact that the 1849 route of the acequia may have cut through this exact location. In fact, Feature 1 may actually represent the remnants of the base of the acequia as it emerged from the wagon yard and skirted the chapel. Added support for this interpretation comes from Level 7 where a thick layer of caliche suddenly appears directly above the sterile black clay of the 8th level. In 1830, Ygnacio Peréz was lining the interior of the acequias with caliche to reduce erosion (Cox 2005:39).

In order to fit the museum building onto the plan of the new Alamo Park, it was necessary to fill the old channel and move that part of the acequia slightly to the east. The source of the fill, nearly all late 19th century household and construction materials, was probably the home of the former San Antonio Mayor Wilhelm Carl August Thielepape demolished when the area was leveled to create the new park. The artifacts all date before 1900 because the city started garbage collection ca. 1887 (Fox et al. 1997:32). The relatively large amounts of Stoneware $(n=18)$ and Porcelain $(n=57)$ confirm that the artifacts came from a comparatively wealthy family home. The few sherds of colonial period ceramics would have been present in the general area from mission times.

\section{The "Ramp"}

A large trench that reached from the north wall of the museum to the sidewalk outside the north wall of the Alamo was excavated by heavy machinery. The excavation was monitored by the archaeological crew. Artifacts were recovered as they were noted and profiles were drawn of the walls of the trench. The width of the trench varied from 40 feet at the north wall of the museum to 15 feet at the sidewalk. The depth of the trench was ca. 10 feet out to the north wall, and then deepened to ca. 16 feet beneath the sidewalk to allow for the installation of an elevator. Although no profile drawings were available for consultation, two pages of notes consisting of basic strata descriptions of the unit's west wall were available among the materials received from the THC. The notes describe 16 strata having been noted in the west wall of the trench. Level 1 was a yellow caliche layer with small gravels in tan sandy construction matrix. Level 2 consisted of tightly packed gravel with small limestone gravels. Level 3 consisted of tightly packed limestone cobbles in light gray caliche matrix. Level 4 is described as dark brown "historical matrix" while Level 5 is a caliche layer. Level 6 was loosely packed limestone with charcoal flecks in light tan caliche matrix. Level 7 was light gray-brown soil with small limestone nodules and charcoal flecks. Level 8 is described as a charcoal layer while Level 9 was dark brown clay with large limestone nodules. Levels 10 through 16 seem to make up the bedrock deposits underlying the site at a depth of around 10 feet. Interestingly, a large mammal bone was noted in Level 11. The depth of the find is unclear nor can we determine whether the bone was culturally modified and associated with other cultural materials or was an isolated specimen. 
Table 5-23. Artifacts Recovered from Southeast Test Pit

\begin{tabular}{|c|c|c|c|c|c|c|c|c|c|}
\hline \multirow{2}{*}{ CLASS } & \multirow[b]{2}{*}{ Data } & \multicolumn{7}{|c|}{ Level } & \multirow[b]{2}{*}{ Grand Total } \\
\hline & & 2 & 3 & 4 & 5 & 6 & 7 & 8 & \\
\hline Activity: Toy & COUNT & 2 & & & 1 & & & & 3 \\
\hline \multirow{2}{*}{ Bone } & COUNT & 14 & 9 & & 152 & 15 & & & 190 \\
\hline & WEIGHT (g) & 38.97 & 21.9 & & 555.81 & 39.94 & & & 656.62 \\
\hline Brick & COUNT & & 1 & & & 5 & & & 6 \\
\hline \multirow{2}{*}{ Bullet } & COUNT & & & & 1 & & & & 1 \\
\hline & WEIGHT $(\mathrm{g})$ & & & & 118.35 & & & & 118.35 \\
\hline Button & COUNT & 4 & & 4 & 1 & & & & 9 \\
\hline Cartridge Casing & COUNT & & & & 1 & & & & 1 \\
\hline Ceramic Figurine & COUNT & & & 2 & & & & & 2 \\
\hline Colonial Ceramic: Lead Glazed & COUNT & 2 & & & 3 & 5 & 1 & & 11 \\
\hline Colonial Ceramic: Tin Glazed & COUNT & 3 & 1 & 2 & 3 & & & 1 & 10 \\
\hline Colonial Ceramic: Unglazed & COUNT & 2 & 1 & 3 & 1 & 21 & & & 28 \\
\hline Construction Fastener & COUNT & 1 & & & & & & & 1 \\
\hline Cut Nail & COUNT & & 34 & 42 & 46 & 32 & 2 & 1 & 157 \\
\hline Debitage & COUNT & & & & 2 & 2 & 6 & 1 & 11 \\
\hline English Ceramic: Porcelain & COUNT & 13 & 11 & 14 & 16 & 2 & & 1 & 57 \\
\hline English Ceramic: Semi-Porcelain & COUNT & 6 & & & 2 & & & & 8 \\
\hline English Ceramic: Stoneware & COUNT & 1 & 4 & 10 & 1 & 1 & 1 & & 18 \\
\hline English Ceramic: White Earthenware & COUNT & 8 & 10 & 17 & 3 & & & & 38 \\
\hline English Ceramic: Yellowware & COUNT & 2 & 1 & 1 & & 1 & & & 5 \\
\hline Flagstone & COUNT & & & 1 & & & & & 1 \\
\hline Flat Glass & COUNT & & & 54 & 58 & 31 & 16 & 2 & 161 \\
\hline Fossil & COUNT & 1 & & & & & & & 1 \\
\hline Glass & COUNT & 322 & 266 & 212 & 173 & 49 & 2 & 7 & 1031 \\
\hline \multirow{2}{*}{ Marine Shell } & COUNT & 1 & & & & & & & 1 \\
\hline & WEIGHT (g) & 1.5 & & & & & & & 1.5 \\
\hline \multirow{2}{*}{ Marine Shell Umbo } & COUNT & 1 & & & & & & & 1 \\
\hline & WEIGHT (g) & 5.31 & & & & & & & 5.31 \\
\hline Metal & COUNT & 2 & 3 & & 1 & 0 & & & 6 \\
\hline Metal Fastener & COUNT & 8 & 3 & & & & & & 11 \\
\hline Metal: lead & COUNT & & 3 & & & & & & 3 \\
\hline Mortar & COUNT & & & 2 & & & & & 2 \\
\hline Nail & COUNT & & 10 & & 4 & 58 & 28 & & 100 \\
\hline Native American Ceramic & COUNT & & 1 & 1 & 2 & 1 & & & 5 \\
\hline Other Ceramic & COUNT & 1 & & & & & & & 1 \\
\hline Other Ceramic: Insulator & COUNT & & 1 & & & & & & 1 \\
\hline Other Ceramic: Porcelain & COUNT & 2 & & & 1 & & & & 3 \\
\hline Other Ceramic: Stoneware & COUNT & 1 & & & & & & & 1 \\
\hline Other Ceramic: Yellowware & COUNT & & & & 5 & & & & 5 \\
\hline Other Rock & COUNT & 2 & 6 & 2 & 2 & 13 & & & 25 \\
\hline Paver & COUNT & 18 & 3 & 2 & 3 & & & & 26 \\
\hline Personal & COUNT & & 1 & & 1 & & & & 2 \\
\hline
\end{tabular}


Table 5-23. Continued...

\begin{tabular}{|c|c|c|c|c|c|c|c|c|c|}
\hline \multirow{2}{*}{ CLASS } & \multirow[b]{2}{*}{ Data } & \multicolumn{7}{|c|}{ Level } & \multirow[b]{2}{*}{ Grand Total } \\
\hline & & 2 & 3 & 4 & 5 & 6 & 7 & 8 & \\
\hline Sewer Pipe & COUNT & 1 & 1 & & & & & & 2 \\
\hline \multirow{2}{*}{ Snail Shell } & COUNT & 1 & 1 & & & & & & 2 \\
\hline & WEIGHT (g) & 0.1 & 0.7 & & & & & & 0.8 \\
\hline Tack Metal & COUNT & & 1 & & & & & & 1 \\
\hline Unid. Metal object & COUNT & & 5 & & 1 & & & & 6 \\
\hline \multirow{2}{*}{ Unidentified metal } & COUNT & 75 & 27 & 36 & 14 & 2 & 27 & 1 & 182 \\
\hline & WEIGHT (g) & 176.78 & 125.9 & 243.4 & 128.79 & 5.09 & 85.25 & 3.02 & 768.23 \\
\hline Wire Nail & COUNT & & 4 & 2 & & 2 & & & 8 \\
\hline Total COUNT & & 494 & 408 & 407 & 498 & 240 & 83 & 14 & 2144 \\
\hline
\end{tabular}

Table 5-24. Breakdown of Artifacts from Southeast Test Pit by Temporal Affiliation

\begin{tabular}{|l|c|c|c|c|}
\hline & \multicolumn{3}{|c|}{ Period } & \\
\hline AU/Level & $\begin{array}{c}\text { 19th } \\
\text { century }\end{array}$ & Colonial & Modern & $\begin{array}{c}\text { Grand } \\
\text { Total }\end{array}$ \\
\hline I/2 & 493 & 7 & & 500 \\
\hline II/3 & 410 & 3 & & 413 \\
\hline III/4 & 345 & 6 & & 351 \\
\hline IV/5 & 315 & 11 & 1 & 327 \\
\hline V/6 & 88 & 27 & & 115 \\
\hline VI/7 & 10 & 1 & & 11 \\
\hline VII/8 & 9 & 1 & & 10 \\
\hline $\begin{array}{l}\text { Total } \\
\text { COUNT }\end{array}$ & 1670 & 56 & 1 & 1727 \\
\hline
\end{tabular}

The Briggs catalog indicates that eight proveniences are associated with the ramp excavations (Table 5-25). Of these, six contain a total of 10,812 artifacts. The bulk $(92 \% ; n=9979)$ of these artifacts recovered during the ramp excavations derive from three of these eight proveniences (SM -12, SM41 and SM7-1). Although at least three of the proveniences (SM-45 thru SM-47) provide some depth, only one of them has artifacts listed in the database (SM-45). Unfortunately, the location information is insufficient to conduct a systematic analysis of the small number of materials derived from this provenience. As a result, the bulk of the artifacts associated with the ramp excavations can only be assigned to the massive ramp excavation without other vertical or horizontal details. The utility of such an analysis unit would be rather minimal and therefore the artifacts recovered from the ramp excavations are not discussed any further.

Table 5-25. Proveniences from Ramp Excavations and Analysis Units Defined by CAR

\begin{tabular}{|c|l|c|c|}
\hline $\begin{array}{c}\text { Provenience/ } \\
\text { Unit }\end{array}$ & Catalogue Description & $\begin{array}{c}\text { Analysis } \\
\text { Unit/Level }\end{array}$ & Lot Number \\
\hline SM-12 & $\begin{array}{l}\text { Ramp construction } \\
\text { excavation }\end{array}$ & unassigned & $1991-237$ \\
\hline SM-41 & $\begin{array}{l}\text { Ramp, east side of } \\
\text { ASM building }\end{array}$ & unassigned & $1991-266$ \\
\hline SM-44 & $\begin{array}{l}\text { Ramp, excavation south } \\
\text { of Sidewalk in Gravels }\end{array}$ & unassigned & $1991-268$ \\
\hline SM-45 & $\begin{array}{l}\text { 6.5 feet below surface, } \\
\text { 4 feet west of palm tree }\end{array}$ & unassigned & $1991-284$ \\
\hline SM-46 & $\begin{array}{l}\text { 9 feet below surface, } 4 \\
\text { feet west of palm tree }\end{array}$ & unassigned & $\begin{array}{c}\text { no artifacts in } \\
\text { database }\end{array}$ \\
\hline SM-47 & $\begin{array}{l}\text { 10 feet below surface, } 4 \\
\text { feet west of palm tree; } \\
1 \text { foot zone, side wall } \\
\text { of ramp }\end{array}$ & unassigned & $\begin{array}{c}\text { no artifacts in } \\
\text { database }\end{array}$ \\
\hline SM-49 & $\begin{array}{l}\text { West profile ramp, level } \\
\text { above pea gravel }\end{array}$ & unassigned & $1991-272$ \\
\hline SM7-1 & Ramp construction & unassigned & $1991-273$ \\
\hline
\end{tabular}




\title{
Chapter 6: Artifact Descriptions
}

\author{
Anne A. Fox, Jennifer L. Thompson and Steve A. Tomka
}

A variety of modern, $19^{\text {th }}$ century and Colonial Period artifacts were collected during the Sales Museum excavations. The results of analyses of these artifacts is presented below beginning with the ceramics.

\section{Ceramics}

\section{Native American Ceramics}

\section{Goliad Plain (n=399)}

This ceramic type was first noted and named during analysis of artifacts from Mission Espíritu Santo at Goliad (Mounger 1959:164). Vessels of this type are hand-built and tempered with bone. Sherd surfaces vary from grayish brown to red orange, and the interiors of the sherds are gray to black, indicating that vessels were fired over an open fire. Vessel shapes include jars, ollas, and bowls.

\section{Rockport Ware $(n=1)$}

Only a single sherd of this ceramic type was recovered. It has a gray surface and a dark gray interior, and the paste contains very fine sand. Ceramics of this type were made by coastal Indians (Suhm and Jelks 1962).

\section{Unglazed Colonial Ceramics}

\section{Valero Red Painted Ware $(n=7)$}

This wheel made ware is identified by red brown bands or wavy lines on a pinkish tan body. The curvature of the sherds suggests that these were large water jars. The type was first identified during excavations in Alamo Plaza (Fox et al. 1976: 67) Sherds vary in thickness from $4 \mathrm{~mm}$ to $7 \mathrm{~mm}$.

\section{Valero Ware (n=304; Figure 6-1a)}

A relatively large number of sherds of unglazed, undecorated ceramics, whose color varies from pinkish tan to reddish yellow (5YR 7/4 to 5YR 6/8), were recovered from all units. All have a fine, silty paste and contain no temper. They are the same color throughout, suggesting that they were fired in a controlled atmosphere such as a pottery kiln. Some display rilling on one or both surfaces probably caused by the use of a pottery wheel, while others have smooth surfaces. Thickness of the sherds varies from $4 \mathrm{~mm}$ to $7 \mathrm{~mm}$. A few direct rim sherds are present, but all sherds are too small to indicate vessel shape. Some sherds display a sharp, even break while others have worn, rounded edges. This alone does not imply differences in manufacture, according to Shephard (1968:137). The apparent use of a pottery wheel and kiln suggests that this ceramic type originated in Mexico. The color and the fact that they have been kiln-fired could possibly indicate that many of these are undecorated parts of Valero Red Painted Ware vessels.

\section{Buff Paste Ware (n=3)}

These sherds have a buff colored paste with occasional very small, white inclusions. They are $8 \mathrm{~mm}$ thick and appear to be wheel made, are the same color throughout, and seem to be from the same vessel.

\section{Tonalá Burnished Ware (n=50; Figure 6-1b)}

This type has a fine gray paste that has a sweet, earthy fragrance when damp. Some of the sherds have delicate red and/or black designs on a burnished surface. The potters at Tonalá, Jalisco, at this time were not using the wheel but were using molds (Charlton and Katz 1979:47). The sherds vary from $4 \mathrm{~mm}$ to $6 \mathrm{~mm}$ in thickness.

\section{Red Burnished Ware (n=40; Figure 6-1c)}

These vessels are dark red with polished surfaces. Matte areas on the interior of bowls and exterior of larger vessels are decorated with burnished designs (Gilmore 1974:63). Sherds vary from $5 \mathrm{~mm}$ to $9 \mathrm{~mm}$ thick.

\section{Piloncillo Mold ( $n=4)$}

These cone-shaped vessels were made to receive hot sugar syrup to form sugar cones, which were a common treat for the mission inhabitants. They were ca. $5 \mathrm{~mm}$ in outside diameter at the base, expanded to ca. $10 \mathrm{~mm}$ at the rim, and stood ca. $15 \mathrm{~mm}$ tall. Fragments of these vessels have been recovered at most of the San Antonio missions.

\section{Comal $(n=3)$}

Round, flat ceramic griddles were in use in Mexico during the colonial period, but were seldom used in the Central Texas area. Here, the comales brought up from Mexico during the 


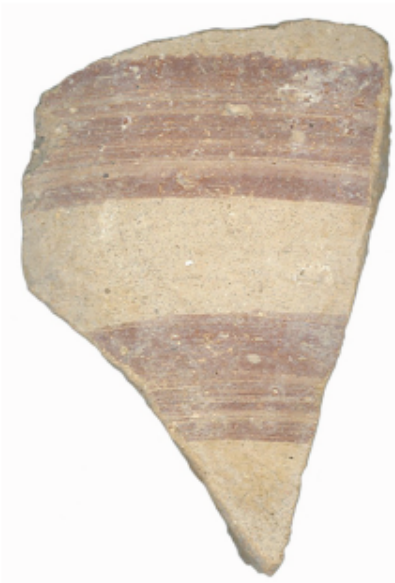

a

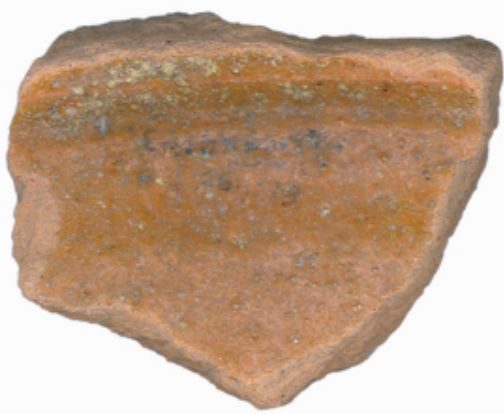

d

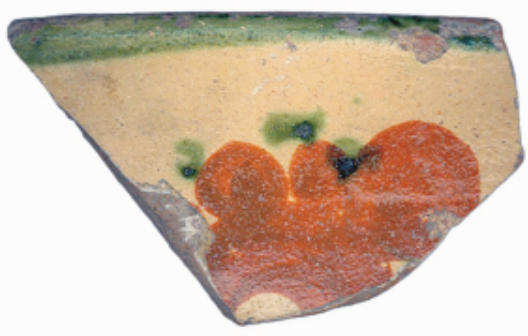

g

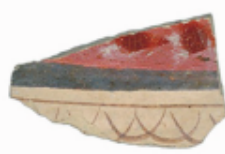

b

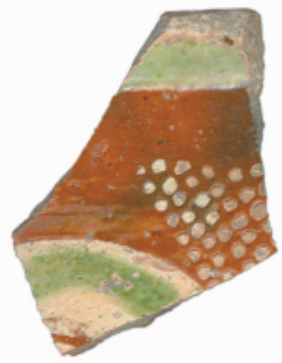

e

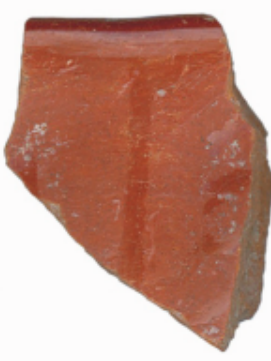

C

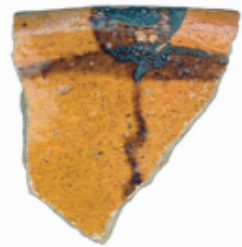

f

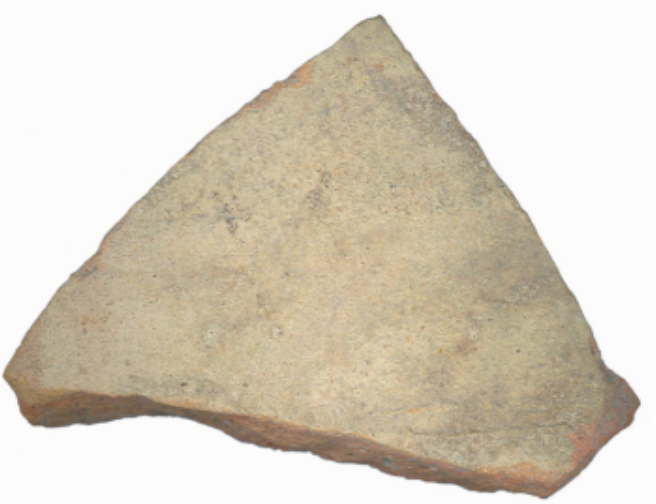

$\mathrm{h}$

Figure 6-1. Colonial Ceramics: (a) Valero Ware; (b) Tonalá Burnished Ware; (c) Red Burnished Ware; (d) Sandy Paste Ware; (e) Galera Ware; (f) Brown on Yellow Ware; (g) Tonalá Glazed Ware; (h) Olive Jar. 
colonial period were usually made of metal, probably because they were so likely to be broken during the mule train's travel. These three sherds are $11 \mathrm{~mm}$ thick.

\section{Flowerpots $(n=5)$}

Terra cotta sherds appear to be from small flowerpots similar to those in use today.

\section{Lead Glazed Colonial Ceramics}

\section{Sandy Paste Ware (n=632; Figure 6-1d)}

Mexican-made, coarse, wheel-made lead glazed wares were the most common household ceramics on $18^{\text {th }}$ century colonial sites. The sandy paste varies from orange to red in color. The glaze ca be a clear one that brings out the color of the paste, or various shades of green, brown, or yellow. The vessels are bowls or ollas of various sizes and thickness. Sherds can vary from $1.5 \mathrm{~mm}$ to $15 \mathrm{~mm}$ in thickness.

\section{Fine Paste Ware $(n=148)$}

A smaller group of sherds of wheel-made vessels with finer, pinkish to red paste have a thin, rough glaze that appears to be immature (not sufficiently fired). Sherds vary from $6 \mathrm{~mm}$ to $8 \mathrm{~mm}$ in thickness.

\section{Galera Ware (n=782; Figure 6-1e)}

Sherds of this type are usually thin $(3 \mathrm{~mm}$ to $4 \mathrm{~mm}$ in thickness) and small. The paste is fine and red, and the glaze is colorless, enhancing the color of the paste beneath it. Vessels are decorated on the outside with brown, yellow, and green designs. The most popular types of vessels in the $18^{\text {th }}$ century were chocolateras and bean pots. The potters in Western Mexico where this ware was made did not use the wheel, but molded their vessels.

\section{Red Brown Ware $(n=5)$}

This type has a red brown glaze over a fine red brown paste. Shallow rilling on the inner surface indicates the use of a potter's wheel. Sherds vary from $4 \mathrm{~mm}$ to $6 \mathrm{~mm}$ in thickness.

Vessels appear to be shallow plates and bowls. Schuetz (1969:51) recorded this type from Mission San Juan Capistrano as Guadalajara Ware.

\section{Dark Brown Ware $(n=2)$}

This type is similar to Galera Ware in paste and method of construction, but is covered with a dark brown lead glaze. The vessel represented in this collection is a bulbous pot with a slightly everted rim about $12 \mathrm{~mm}$ deep. Identical vessels have been found at Presidio La Bahia at Goliad and Mission Refugio (Tennis 2002:207).

\section{Smooth Brown Ware $(n=20)$}

Red paste covered with a thick, smooth brown glaze identifies this ceramic type. Vessels are shallow plates with thickened rims, sometimes decorated with dark brown lines. Sherds of this type, varying from $5 \mathrm{~mm}$ to $8 \mathrm{~mm}$ in thickness, have been found on sites of the late $18^{\text {th }}$ and early $19^{\text {th }}$ centuries in the San Antonio area.

\section{Red Ware $(n=133)$}

Fine paste sherds with a clear to brown glaze are relatively thin ( $1 \mathrm{~mm}$ to $2 \mathrm{~mm})$. This is a miscellaneous collection of small sherds that could not be further identified as to type. Several vessels appear to be small, shallow bowls with a ring foot.

\section{Brown on Yellow Ware (n=16; Figure 6-1f)}

These sherds average about $6 \mathrm{~mm}$ in thickness and have a yellow glaze over a yellow to orange fine-grained paste. Brown linear designs have been applied under the glaze. The vessels appear to have been small bowls with a flat base.

\section{Tonalá Glazed Ware (n=14; Figure 6-1g)}

Both surfaces of these sherds are generally coated with a cream colored enamel decorated with green, black, and red brown designs. The vessels represented are small bowls with a ring foot.

\section{Black Luster Glaze $(n=16)$}

Two types of ceramic ware with a black, lustrous glaze have been found on colonial sites in Texas. Those with a buff colored paste were made in Santa Fe, Michoacan, while those with a terra cotta paste came from Puebla (Schuetz 1969:52). Thirteen buff-bodied sherds in this collection are $3 \mathrm{~mm}$ to 5 $\mathrm{mm}$ thick and one rim sherd has evidence of a molded design. Three terra cotta bodied sherds $7 \mathrm{~mm}$ in thickness represent a heavier vessel, perhaps a jar or pitcher. 


\section{Olive Jars (n=20; Figure 6-1h)}

Large, heavy ceramic jars were used to ship wine and olive oil during the colonial period. They were usually covered on the interior with a green glaze and often had a white slip on the exterior. Sherds in this collection have a reddish tan paste and average ca. $12 \mathrm{~mm}$ thick.

\section{Unidentified ( $n=126)$}

One group of lead glazed sherds could not be confidently identified as to type. Some were too small, or altered by burning, or otherwise were not true to color.

\section{Tin Glazed Colonial Ceramics}

\section{Puebla Polychrome (n=26; Figure 6-2a)}

This is a tin glazed ceramic decorated with swaths of cobalt blue and thin black lines in lace or spider web patterns. It was made in the town of Puebla, Mexico from about 1650 to 1725 (Goggin 1968:179; Deagan 1987:82). A few sherds of Puebla Polychrome have been recovered from deeper locations in the Second Patio of the convento of the mission (Schuetz 1973:21; Ivey and Fox 1997:25). Therefore it is not surprising that 26 sherds of this type were recovered during these excavations in the area to the north of the museum, between the museum and Houston Street. The presence of this type of ceramic in that particular area suggests that there was some activity there before the construction of the mission convento.

\section{San Agustín Blue on White (n=7; Figure 6-2b)}

Floral decoration on this type is done in two shades of blue, with the darker shade more prominent. Designs cover the inside of plates, and light blue loops appear on the outside. It is tentatively dated from 1700 to 1780 .

\section{Puebla Blue on White (n=53; Figure 6-2c)}

The plate design consists of two blue bands beneath the rim from which are suspended a row of single blue petals alternating with a single blue flower. The central design on the base is either a long-legged crane or a floral arrangement. This type was made primarily in the town of Puebla in the early $18^{\text {th }}$ century and copied in other towns later in the century.

\section{San Elizario (n=33; Figure 6-2d)}

The decoration on this type is identical to that of Puebla Blue on White except for brown bands framing the blue rim band and brown accents on the blue petals and flowers. The crane in the center has brown legs and beak. This type is estimated to date from 1755 to 1780 in Texas (Ivey and Fox 1999:37).

\section{Monterey Polychrome (n=23; Figure 6-2e)}

On this type, beneath a similar orange band, are suspended large yellow ovals, orange spirals, and green fronds. This has been found in late $18^{\text {th }}$ century deposits at Mission Espíritu Santo and Presidio La Bahia at Goliad as well as late $18^{\text {th }}$ century deposits at the San Antonio missions.

\section{Huejotzingo (n=35; Figure 6-2f)}

Decoration on this ceramic is limited to a single band of blue at the rim, which usually laps over slightly onto the other side. The band is generally dark blue, but occasionally appears in green or yellow. One example of each of these is included in this collection. This type is not useful for dating, since it was made throughout the $18^{\text {th }}$ century and into the $19^{\text {th }}$ century.

\section{Puebla Blue on White II (n=41; Figure 6-2g)}

This design can be considered a sub-type of Puebla Blue on White, but dates to the late $18^{\text {th }}$ century and is only found on the outside of bowls and cups. The design consists of two or three pale blue bands beneath which are floral-type arrangements of dark blue petal-shaped dots. Two additional light blue bands usually form the bottom of the design.

\section{Guanajuato (n=59; Figure 6-2h)}

The paste of this type is dark terra cotta in color. The background enamel often has a greenish tint. The decorations are floral, geometric, or wavy lines in red brown and green. It appears on all Texas sites in the early 1800s.

\section{Molded Blue on White (n=3)}

This late $18^{\text {th }}$ century ceramic type has a molded, undulating rim beneath which is a thin brown line, and then light blue whirls and flowers with dark blue accents and brown dots over a bright yellow background. A similar vessel is in the collection at Presidio La Bahia at Goliad, which would date it to post-1750.

\section{San Diego Polychrome $(n=6)$}

Ceramics with this pattern have brown-bordered orange rim bands from which are suspended groups of orange, yellow, and green balls bordered by dark brown lines. Alternating 


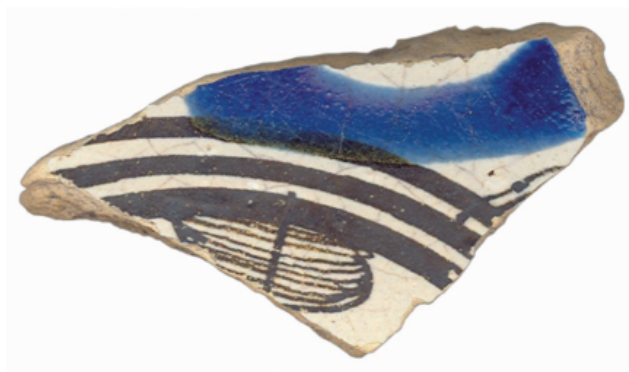

a

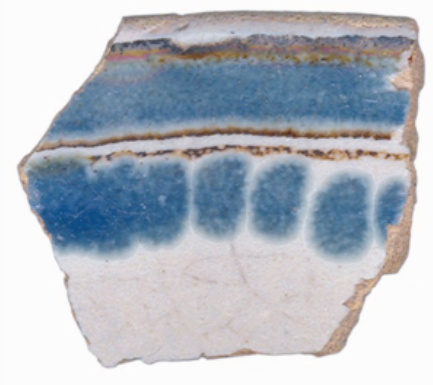

d

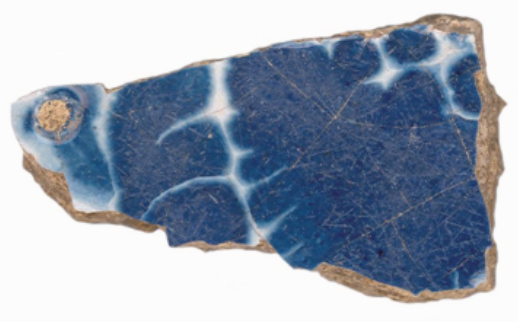

b

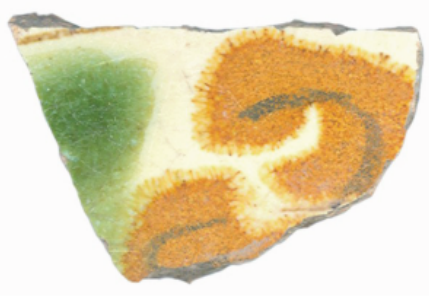

e

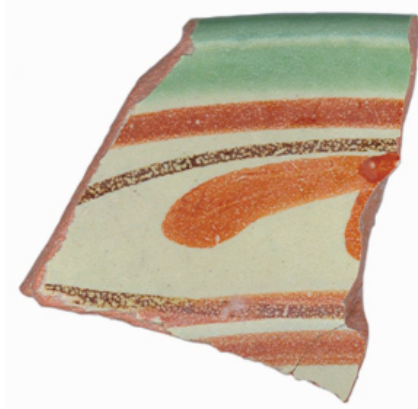

$\mathrm{h}$

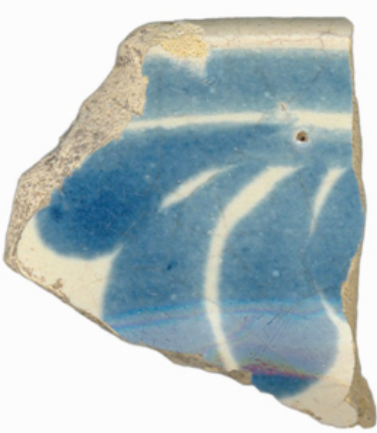

C

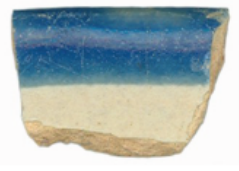

f

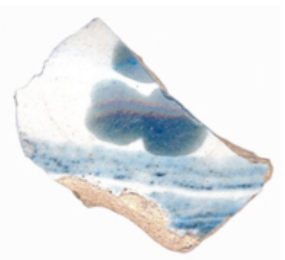

g 5

\begin{tabular}{|c|c|c|c|c|}
\hline & 1 & 2 & 3 & 4 \\
\hline 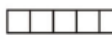 & & $\exists$ & F & $\exists$ \\
\hline
\end{tabular}

Figure 6-2. Tin Glazed Wares: (a) Puebla Polychrome; (b) San Agustin Blue on White; (c) Puebla Blue on White; (d) San Elizario; (e) Monterey Polychrome; (f) Huejotzingo; (g) Puebla Blue on White II; (h) Guanajuato. 
with these are triangles of green and yellow. This type appears in Texas as early as the 1770s (Ivey and Fox 1981:35).

\section{Orange Band Polychrome $(n=2)$}

The decoration on this ceramic type is arranged similarly to that on Puebla Blue on White, except that the band beneath the rim is yellow or orange and the suspended petals are green. It has been found in California between 1800 and 1830 (Barnes and May 1972:12-13).

\section{La Bahia Polychrome (n=2)}

On this type blobs of green, yellow, and orange and blue dots are arranged between thin brown lines that run in loops around them beneath a yellow rim band similar to those described above. This type had up to the present only been identified in the artifacts from Presidio La Bahia, which dates it in the last half of the $18^{\text {th }}$ century.

\section{Wavy Rim Band (n=32)}

This is a 1775 to 1825 version of Huejotzingo Ware (Seifert 1977:71). It is also occasionally found in yellow or green. The lower edge of the rim band is wavy rather than straight. In this collection 24 sherds are decorated with blue and 8 with green.

\section{Puebla Blue on Blue $(n=4)$}

This variant of Puebla Blue on White appeared in the late $18^{\text {th }}$ century. The exterior of the vessel was brushed with a thin blue wash over which dark blue designs were painted. A dark blue rim band extends over the lip. On the reverse side of the vessel are pale blue interconnected loops.

\section{Unidentified Polychrome Wares $(n=109)$}

These sherds are too small or are not identifiable as to type, but have small spots of various colors.

\section{Unidentified Blue on White Wares (n=153)}

Sherds that are too small to identify or that only display small touches of blue are included in this category.

\section{Puebla Plain Ware $(n=540)$}

The large number of white, undecorated sherds can be parts of otherwise decorated vessels, or totally plain vessels which were made in Mexico throughout the $18^{\text {th }}$ century (Lister and Lister 1974:30).

\section{Tumacacori Polychrome (n=5)}

Both sides of these vessels are covered with a blue glaze, decorated with various floral designs in yellow, orange, blue and green with black lines. In general, these vessels can be dated ca. 1810 to 1860 (Barnes and May 1972:11) judging from the designs represented.

\section{Faience $(n=3)$}

A few tin glazed earthenwares that were made in France always seem to turn up on colonial sites in San Antonio. Those in this collection are what is referred to as faince brune, which has a white or very pale blue glaze on the inside of the vessel and a dark brown glaze on the outside. This type was made in Rouen, France.

\section{Refined English Earthenwares}

\section{Creamware $(n=6)$}

Late $18^{\text {th }}$ century earthenwares made in England were first made with a cream colored paste. Subsequent attempts to make white-bodied ware progressed to a lighter and lighter cream. This type went out of fashion ca. 1820.

\section{Undecorated Whiteware $(n=556)$}

This type with a pure white body was developed in England ca. 1810 (Ramsday 1976:152). Sherds with no decoration could be from entirely undecorated vessels or from undecorated portions of otherwise decorated ones.

\section{Edgeware (n=110; Figure 6-3a)}

The only decoration on this ceramic type is a molded and painted shell or feather edging at the rim, most commonly in blue or green. It was most popular from the 1780s through the 1830s, and by the 1850s it was one of the cheapest wares available (Miller n.d.: 1-2). Edgeware was common on early $19^{\text {th }}$ century sites in San Antonio.

\section{Transfer Decorated Ware (n=168; Figure 6-3b)}

Designs on this ceramic type were transferred from copper plates onto unglazed whiteware vessels, then glazed and fired. At first $(1820$ - 1840) such wares were printed in blue, but around 1840 brown, green, yellow, red, black, and flow blue designs were introduced. 


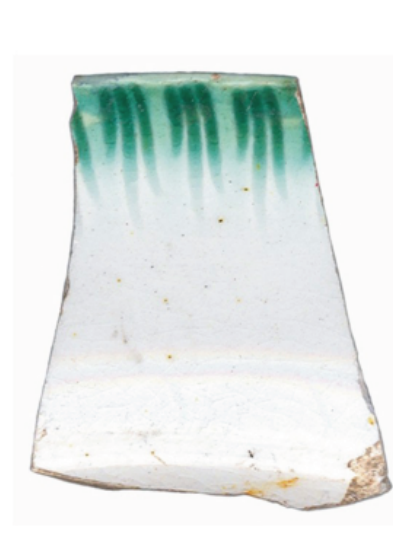

a



b

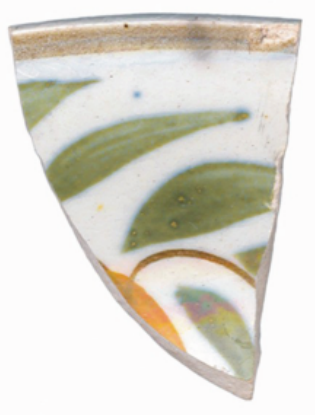

C

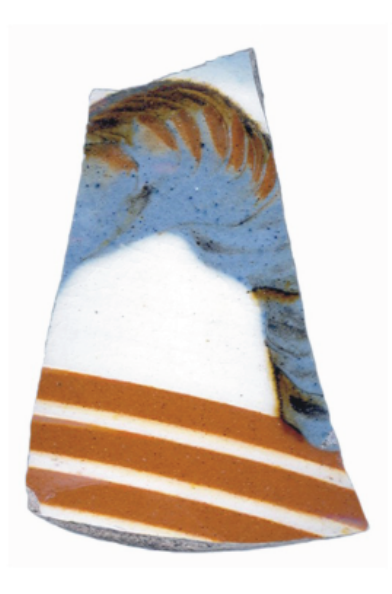

d

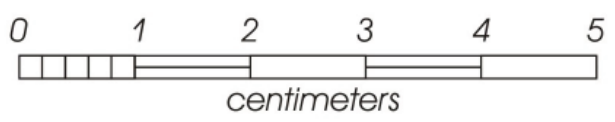

Figure 6-3. Refined English Ware: (a) Edgeware; (b) Transfer Decorated Ware; (c) Hand Painted Ware; (d) Banded Slip Ware.

\section{Hand Painted Ware (n=357; Figure 6-3c)}

Ceramics of this type have painted designs under the glaze in shades of brown, blue, green, and yellow. They were imported into Texas during the early $19^{\text {th }}$ century.

\section{Banded Slip Wares (n=184; Figure 6-3d)}

This type can be recognized by the application of colored slips in bands and/or dots and worms. Annular and/or rouletted designs are often also present. The colors include bright blue, earthen brown, yellow, green, and black.

\section{Spatter Ware $(n=4)$}

Ceramics of this type have areas covered with small dots of a single color. Spattered decoration is usually combined on a vessel with hand painted or sponge-printed designs. The sherds in this collection are spattered with blue or red. This type of ceramics was imported between 1820 and the 1850 s, with a peak of importance in the decade between 1830 and 1840 (Robacker and Robacker 1978:32).

\section{Band and Line Decoration $(n=2)$}

This ceramic type shows up on late $19^{\text {th }}$ century sites in San Antonio. Vessels are simply decorated with one or two thin bands of color near the rim and the remainder undecorated. There is very little information available on where this was being made.

\section{Luster Ware $(n=4)$}

This ceramic type was made in England as early as 1810 (Hughes 1967:85). Two different styles are present in this collection. A whiteware sherd is decorated with pink luster, and three copper luster sherds have a red ware body. Both are quite typical types found in mid- $19^{\text {th }}$ century San Antonio. 


\section{Later American Ceramics}

\section{Semi Porcelain $(n=12)$}

This late $19^{\text {th }}$ century ceramic is well vitrified but not as highly fired as porcelain. When broken, the body appears dull rather than the glass-like texture of porcelain (Lehner 1898:534).

\section{Ironstone $(n=81)$}

This ceramic type was patented in England in 1813 by Charles Mason (Ramsday 1976:153). The vessels were generally plain and heavy utilitarian plates and serving dishes. It was imitated in American potteries as White Granite Ware (Newcomb 1947:223), and was used in San Antonio throughout the late $19^{\text {th }}$ and early $20^{\text {th }}$ centuries. Six of the sherds recovered represent a large bowl decorated with a black transfer design.

\section{Yellowware $(n=21)$}

Thirteen of the recovered sherds of this type are from heavy, utilitarian vessels with a clear glaze. Six of them have a brown mottled glaze generally referred to as a Rockingham glaze. The vessel represented by two sherds was probably a small pitcher, white glazed on the interior and blue painted on the outside with white embossed grape vines around the neck - a most unusual piece. Yellowware was present on American sites from 1830 to 1900 (Yakubik 1990:375).

\section{Stonewares}

This type gets its name from its dense and hard nature. In order to properly vitrify, stoneware must be fired to a temperature between 1200 and 1300 degrees Centigrade. Although technically stoneware does not require a glaze to prevent leaking, glazes were found to enhance the appearance and allow easier cleaning (Greer 1981:15-16).

\section{Unglazed $(n=2)$}

These sherds from the same stoneware churn or jar are unglazed, but otherwise resemble American utility stoneware, varying from 10 to $12 \mathrm{~mm}$ in thickness.

\section{Salt Glazed $(n=12)$}

This type of glaze is created by introducing salt into the kiln after the vessels are fired to a high temperature. The salt immediately vaporizes and coats the surfaces of the vessels. This glaze was used throughout the nineteenth century (Greer 1981:180).

\section{Alkaline Glazed (n=7)}

During the second half of the $19^{\text {th }}$ century the use of this glaze on stoneware was popular throughout the southern United States, probably because the ingredients - wood ash, clay, and sand - were readily available to potters (Greer 1981:203).

\section{Albany Slip Glazed $(n=230)$}

The clay used to make this dark brown slip was first used during the first quarter of the $19^{\text {th }}$ century in Albany, New York. Before long, other clays that produced a similar slip were being shipped throughout the United States from Indiana and Michigan as well. Today most slip glazes that produce a similar color are called Albany Slip unless they can be positively identified as being from a local clay source. This slip glaze was used on the interior of various stonewares.

\section{Leon Slip Glazed $(n=128)$}

The Meyer family began a pottery in Atascosa County in 1887, producing salt glazed wares. By about 1895 they changed to a clay slip glaze, using clay from a site on the bank of Leon Creek in Bexar County. The resulting color of this slip varied, depending on the thickness of the slip and the firing conditions, from yellow to brown to green. The Meyer family continued to produce from 1900 to 1945 (Greer and Black 1971:8).

\section{Bristol Glazed $(n=10)$}

The clean, white Bristol glaze that was first introduced during the Victorian period in England was displayed at the New Orleans Exposition of 1884 and quickly caught on in the United States. Before 1920 vessels with Bristol glaze on the outside and Albany Slip on the inside became popular in this country. After 1920 both the inside and the outside of stoneware vessels were coated with Bristol glaze.

\section{Stoneware Bottles}

\section{Unglazed Ware $(n=5)$}

A few sherds of gray brown stoneware are too thin $(5 \mathrm{~mm})$ to be from utility wares. They probably represent European-made bottles.

\section{Brown Glazed Ware $(n=14)$}

These are fragments of what are probably European-made gin bottles or British ink bottles. Fragments of these objects are often found on late $19^{\text {th }}$ century sites in Texas. 


\section{Bristol Glazed Ware $(n=12)$}

Hundreds of ceramic bottles were made in Scotland and shipped to post-Civil War sites in Texas. Most of them contained ginger beer or ale. The neck and rim were usually covered with a light yellow brown glaze, while the body had a cream colored Bristol glaze.

\section{Porcelain}

Porcelain is the product of fine-grained clay mixed with Kaolin and fired at a very high temperature. It is vitrified and translucent (Yakubik 1990:315). By the mid-eighteenth century it was being made in Germany, France, and England (Miller and Stone 1970:90) but was not manufactured in the United States until ca. 1880 (Yakubik 1990:317).

\section{Undecorated $(n=89)$}

Sherds representing porcelain plates and cups with no decoration are particularly common on late $19^{\text {th }}$ century sites in San Antonio.

\section{Decorated $(n=16)$}

Five transfer-decorated sherds are in this collection. Four sherds have traces of gilding. There are four porcelain sherds with painted decoration either under or over the glaze, and three have decalcomania designs.

\section{Oriental Porcelain}

\section{Chinese porcelain $(n=4)$}

Porcelain made in China usually has a lightly blue gray cast. Of the sherds in this collection, two are undecorated, one is decorated under glaze in blue, and one has an over glaze design painted in red, white, and black.

\section{Glass}

Large quantities of glass fragments of various colors are typical of $19^{\text {th }}$ century deposits. They represent bottles and jars that held medicines and food products as well as wine and liquor.

\section{Clear glass $(n=648)$}

These fragments are primarily from medicine bottles, some with embossed labels from local drug stores. A few are fragments of chimneys from kerosene laps which, along with candles, were the predominant means of household lighting in San Antonio until the early $20^{\text {th }}$ century.

\section{Aqua glass $(n=341)$}

Bottle fragments of this color tend to be slightly older, before it was more popular to bleach containers.

\section{Brown glass $(n=788)$}

Most of these fragments are probably from whiskey bottles, a very few with embossed letters. Olive green (695 dark olive green, 809 light olive green). Of all the glass, this type is most likely to represent wine bottles. Most of the olive glass in the colonial sites in the San Antonio area is from wine bottles, as well as from $19^{\text {th }}$ century sites. It is also interesting to note that fragments of olive green wine bottles were found during the 1979 excavations in the north courtyard. These appeared to be discards from the Grenet or the Hugo \& Schmeltzer store in that area (Ivey and Fox 1997:32). In addition, one wire bottle clamp such as those used to hold the cork on a wine bottle in place (Greer 1967:48) was recovered from the Southeast Pit in Level 6.

\section{Cobalt glass $(n=39)$}

Most $19^{\text {th }}$ century deposits contain a few cobalt blue bottle medicine bottle fragments.

\section{Amber glass $(n=26)$}

This glass color is generally minimally present on $19^{\text {th }}$ century sites.

\section{Bright green glass $(n=102)$}

Glass of this color usually represents soda water or other soft drink bottles of the early $20^{\text {th }}$ century.

\section{Milk glass $(\mathbf{n}=19)$}

Jars of this type of glass are usually used for $19^{\text {th }}$ to early $20^{\text {th }}$ century cosmetic or medicinal salves.

\section{Metal Objects}

Numerous metal objects were recovered, most of which can be dated to the $19^{\text {th }}$ century occupation by the U.S. Army or 
nearby civilian neighbors to the east of the Alamo. Among these are occasional colonial artifacts from the mission period.

\section{Horse Equipment}

The most numerous horse-related objects are horse and mule shoes, some still bearing nails that remained when the farrier removed them. Most came from the first level or what was once the surface before the landscaping for the park in 1937. One mule shoe came from the fill of the acequia below the southeast corner of the museum.

Remains of the blacksmith's operations were numerous iron chunks identifiable as "cut-offs". Most of these would have resulted from the fitting of the shoe to the horse's hoof. Large numbers of these are present in the vicinity of $19^{\text {th }}$ century military blacksmith shops (Fox 1976:36). The comparatively large number of these suggests that the Army's blacksmith shop was somewhere in this area.

Few other objects were recovered that can be related to the military horses. Two harness buckles, a singletree fitting, and a bridle cheek plate can be dated to the $19^{\text {th }}$ century. The only colonial horse-related object is a coscojo or jingle from a Spanish ring bit (Simmons and Turley 1980:101).

\section{Household Objects}

Remarkably little metal household material is present in this collection, which includes fragments of a bucket and a thin metal container, a piece of furniture hardware and a brass tack that may have come from upholstery. The rest of the metal housekeeping objects included two serving spoon fragments, a cast iron pot leg, a key for opening a tin can, and a mediumsized kitchen knife.

Personal artifacts include two fragments of a bone comb, a belt buckle (Figure 6-4a), a shoe heel reinforcing tap, a pocketknife (Figure 6-4b), and an object that may be a letter opener. Clay pipe fragments consist of six white clay pipe stem fragments and three fragments of red clay lead glazed pipe bowls. A large collection of buttons (43 total) consists of fifteen small shell and porcelain buttons, eleven bone buttons, ten metal buttons dating to the $19^{\text {th }}$ century and six turn of the $18^{\text {th }}$ century copper buttons, and one military button that appears to be related to Texas troops (Albert 1969:250-251).

Artifacts related to amusement include a number of circular gaming pieces (Figure 6-4c-e) made from various colonial ceramics, seven clay marbles, several fragments of porcelain doll dishes, and two porcelain doll head fragments. Several pieces of a slate tablet and a slate pencil were also found.
An interesting collection of $18^{\text {th }}$ century glass beads varying from small $(2-4 \mathrm{~mm}$ ) to large (over $6 \mathrm{~mm}$ ) in various colors was recovered from throughout the area from Trench 1 to the north wall within the Ramp excavation. These also included two bone beads from the deeper levels and one very small square jet rosary bead. In addition, a fragment of a colonial copper crucifix with clear glass sets (Figure 6-4f) was also found.

\section{Heavy Metal Parts and Tools}

Heavy objects include a few machinery parts and a number of metal pipe fragments. Tools represented are a hammer head and several files and chisels.

\section{Ammunition}

Five metal cartridge casings were recovered among the $19^{\text {th }}$ century deposits. Two were 22 caliber, one 35 caliber, one 50 caliber and one unidentified.

\section{Construction Materials}

As might be expected, a large amount of material recovered was the result of the demolition of various $19^{\text {th }}$ century buildings in the general vicinity of the northeast corner of the Alamo at the time of clearing for the park.

\section{Cut nails $(n=1687)$}

By far the most numerous are these nails that were in use throughout the $19^{\text {th }}$ century.

\section{Wire nails $(n=399)$}

This type did not come into the area until about the early $20^{\text {th }}$ century.

\section{Unidentified nails $(n=614)$}

Many nails were too rusted or broken to allow identification.

\section{Bricks (n=275)}

Mostly small pieces, these fragments were sometimes difficult to date. About $80 \%$ are colonial bricks such as were made at the missions (Ivey et al. 1997:233). These were probably the product of remodeling or later demolition in the convento area of the mission. 


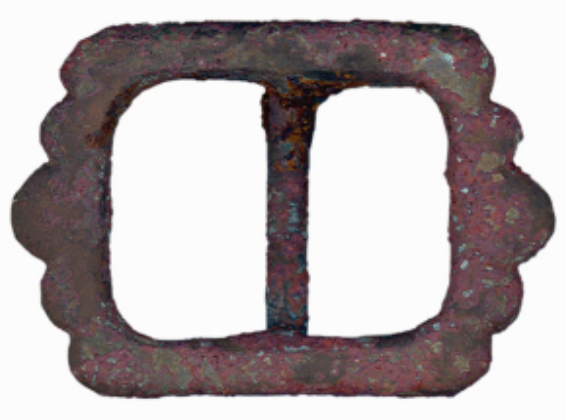

a

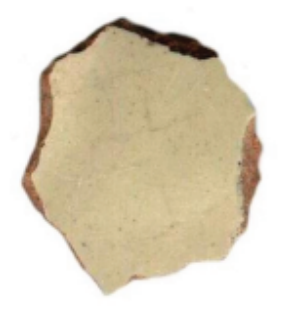

C

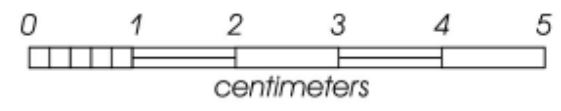

d

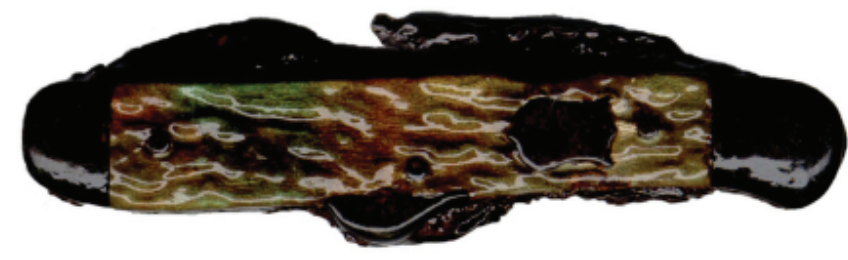

b
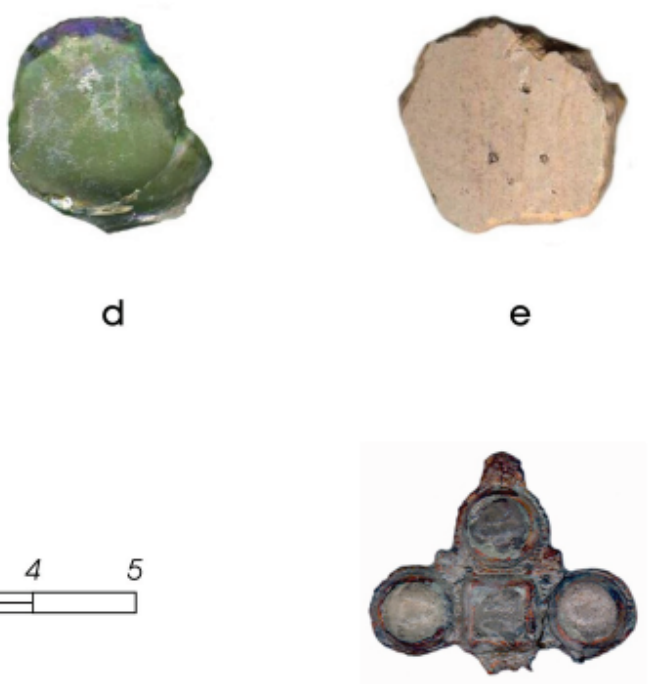

f

Figure 6-4. Personal Items: (a) belt buckle; (b) pocketknife; (c-e) gamming pieces; (f) crucifix.

\section{Plaster $(n=51)$}

Numerous chunks of thick $19^{\text {th }}$ century plaster, painted white, probably came from the Thielepape house.

\section{Window glass $(n=1054)$}

By far the largest number of these $(n=656)$ fragments came from the Southeast Pit, which was the unit closest to the Thielepape house demolition and therefore would have received the largest share of that material. Another surprisingly large amount $(n=244)$ was recovered from the machine excavation of the Ramp Unit, some of which was thick, plate glass fragments. There is no way top tell where the materials from that excavation originated.

\section{Electric fixtures $(\mathbf{n}=9)$}

This small collection of porcelain electric-related fragments probably came from an upper class home that survived into the $20^{\text {th }}$ century such as the Thielepape house. 


\section{Hardware $(n=2)$}

Two ceramic doorknobs would also have come from a late $19^{\text {th }}$ - early $20^{\text {th }}$ century home. One is white porcelain, the other a brown mineral variety such as were advertised in the Montgomery Ward Catalog of 1895 (Dover Publications, Inc.1969:375).

\section{Lithic Technology}

Several tool forms are present in the Sales Museum collection of artifacts, but the level of provenience information is not specific enough to ascertain whether some of the lithic artifacts are from pre-Colonial occupation of Mission San Antonio de Valero. We know from previous archaeological work that a prehistoric site is preserved under the colonial occupation. Historically, we also know that Native American groups inhabited the mission while continuing to use their knowledge of lithic technology thereby leaving a signature of prehistoric technology in the historic period.

Without tight depth control, the level of analysis is limited in this study to the form of artifacts and technological descriptions. Several tool types and debitage from every stage of core reduction are present in the sample. Tool types described here are gunflints, bifaces, projectile points, unifaces, scrapers, gravers, and knives. When possible the blank stage of the tool was recorded. For gunflints and projectile points, length, width, and thickness were measured.

\section{Gunflints}

Twenty-eight gunflints were excavated in the vicinity of the Sales Museum (Table 6-1). Three manufacturing techniques

Table 6-1. Gunflints Recovered from the Alamo Sales Museum Excavations

\begin{tabular}{|c|c|c|c|c|c|c|c|c|c|}
\hline Lot Number & Provenience & $\begin{array}{c}\text { Max } \\
\text { Length }\end{array}$ & $\begin{array}{c}\text { Max } \\
\text { Width }\end{array}$ & $\begin{array}{c}\text { Max } \\
\text { Thickness }\end{array}$ & Manufacture & Blank & $\begin{array}{l}\text { Fire } \\
\text { Arm* }\end{array}$ & $\begin{array}{l}\text { Flaking } \\
\text { History }\end{array}$ & Comments \\
\hline 1991-043-007 & sm1-29 & 17.1 & 13.9 & 6.3 & unifacial & flake & pistol & reflaked & three edges used \\
\hline 1991-273-194 & $\operatorname{sm} 7-1$ & 24.2 & 14.3 & 10.1 & unifacial & flake & pistol & not reflaked & $\begin{array}{l}\text { thick broken flake with four } \\
\text { edges used; }\end{array}$ \\
\hline 1991-089-042 & sm2-34 & 21.7 & 15.3 & 5.4 & unifacial & flake & pistol & reflaked & thin flake; tertiary \\
\hline 1991-273-183 & $\operatorname{sm} 7-1$ & 20.6 & 17.4 & 5.7 & unifacial & blade & pistol & not reflaked & three edges used; \\
\hline 1991-237-114 & $\mathrm{sm} 12$ & 31.2 & 18.5 & 7.3 & unifacial & blade & musket & reflaked & three edges used; \\
\hline 1991-273-195 & $\operatorname{sm} 7-1$ & 31.3 & 19 & 10.2 & unifacial & indeterminate & musket & reflaked & two edges used; \\
\hline \begin{tabular}{|l|} 
1991-190-003 \\
\end{tabular} & sm3-31 & 25.8 & 19.4 & 9.2 & bifacial & recycled biface & rifle & not reflaked & four edges used; \\
\hline 1991-237-110 & $\mathrm{sm} 12$ & 20.5 & 19.8 & 8.8 & unifacial & indeterminate & pistol & reflaked & four edges used; \\
\hline 1991-273-184 & $\operatorname{sm} 7-1$ & 20.5 & 20.3 & 7.9 & unifacial & blade & pistol & $\mathrm{n} / \mathrm{a}$ & $\begin{array}{l}\text { black chert, poss. British; four } \\
\text { edges used; }\end{array}$ \\
\hline 1991-273-192 & $\operatorname{sm} 7-1$ & 34.8 & 21.3 & 8.3 & unifacial & flake & musket & not reflaked & $\begin{array}{l}\text { marginally retouched; used on } \\
\text { four edges; }\end{array}$ \\
\hline 1991-118-024 & sm2-62 & 29.4 & 21.4 & 8 & unifacial & indeterminate & rifle & not reflaked & $\begin{array}{l}\text { marginally retouched; four } \\
\text { edges used; }\end{array}$ \\
\hline 1991-089-041 & sm2-34 & 24.5 & 21.6 & 6.1 & unifacial & flake & pistol & reflaked & four edges used; \\
\hline \begin{tabular}{|l|}
$1991-237-198$ \\
\end{tabular} & $\mathrm{sm} 12$ & 27.1 & 21.7 & 8.1 & bifacial & recycled biface & rial & reflaked & four edges used; \\
\hline 1991-064-018 & sm2-9 & 30.1 & 22.3 & 7.3 & unifacial & flake & rifle & not reflaked & two used edges; \\
\hline 1991-273-189 & sm7-1 & 24.2 & 23.3 & 11 & unifacial & flake & pistol & reflaked & three edges used; \\
\hline $1991-273-188$ & $\operatorname{sm} 7-1$ & 25.5 & 23.6 & 6.7 & bifacial & recycled biface & rifle & not reflaked & $\begin{array}{l}\text { marginally retouched; four } \\
\text { edges used; }\end{array}$ \\
\hline 1991-273-187 & sm7-1 & 31.1 & 24.2 & 9.3 & unifacial & flake & musket & reflaked & $\begin{array}{l}\text { marginally retouched; used on } \\
\text { four edges; }\end{array}$ \\
\hline 1991-273-213 & $\operatorname{sm} 7-1$ & 29.5 & 24.3 & 7.9 & bifacial & recycled biface & rital & reflaked & three edges used; \\
\hline 1991-237-197 & $\mathrm{sm} 12$ & 31.6 & 25.1 & 9.1 & bifacial & recycled biface & musket & reflaked & three edges used; \\
\hline $1991-237-277$ & $\mathrm{sm} 12$ & 26.9 & 25.8 & 8.7 & unifacial & flake & rifle & not reflaked & four edges used; \\
\hline \begin{tabular}{|l|}
$1991-237-112$ \\
\end{tabular} & sm12 & 30.6 & 26.2 & 10 & bifacial & recycled biface & musket & $\mathrm{n} / \mathrm{a}$ & four edges used; \\
\hline 1991-085-021 & sm2-3 & 33.1 & 26.5 & 9.9 & bifacial & recycled biface & musket & not reflaked & four edges used; \\
\hline \begin{tabular}{|l|}
$1991-237-276$ \\
\end{tabular} & $\mathrm{sm} 12$ & 28.7 & 27 & 9.5 & unifacial & flake & rifle & $\mathrm{n} / \mathrm{a}$ & four edges used; \\
\hline 1991-273-217 & \begin{tabular}{|l|} 
sm7-1 \\
\end{tabular} & 28.4 & 29.1 & 13 & unifacial & recycled uniface & rifle & not reflaked & four edges used; \\
\hline $1991-273-193$ & $\operatorname{sm} 7-1$ & 34 & 33.7 & 9.4 & unifacial & flake & musket & reflaked & $\begin{array}{l}\text { marginally retouched; four } \\
\text { edges used; }\end{array}$ \\
\hline 1991-085-021 & sm2-3 & 27.6 & & 8.8 & bifacial & recycled biface & rial & reflaked & longitudinal fragment; \\
\hline $1991-237-113$ & $\operatorname{sm} 12$ & & & 5.1 & unifacial & blade & musket & $\mathrm{n} / \mathrm{a}$ & $\begin{array}{l}\text { longit., edge fragment; honey } \\
\text { colored, poss. French; }\end{array}$ \\
\hline 1991-273-196 & $\operatorname{sm} 7-1$ & 22 & & 8.7 & unifacial & indeterminate & pistol & reflaked & $\begin{array}{l}\text { longitudinal fragment; one } \\
\text { edge used; }\end{array}$ \\
\hline
\end{tabular}

* fire arm defined based on maximum length (Witthoft 1966) 
were discerned from analysis of this small gunflint collection. Some of the specimens were made on recycled artifacts such as bifaces and unifaces, others were made on flake blanks, and yet others were made on blades. Four specimens are too fragmentary or too extensively flaked to determine the blank employed in their manufacture. Figure 6-5 presents a selection of gunflints.

\section{Specimens made on recycled artifacts $(n=9)$}

Nine gunflints were made on recycled artifacts. Eight represent recycled bifacial artifact fragments and one is a recycled unifacial artifact fragment. In the case of these artifacts, the manufacturing process began with a broken biface and/or uniface. Next, one or more edges of the artifact were re-flaked if necessary to provide the appropriate edge angle. In a few instances, the fragment was extensively re-flaked to reduce its size and shape it, but most recycled fragments exhibit only minimal marginal retouch.

\section{Specimens made on blades $(n=4)$}

Four gunflints were made on blades. These blanks retain the parallel edges of the parent blade and have either one or two central ridges and flat dorsal surfaces characteristic of blades. As with the majority of the gunflints, those made on blade fragments are only marginally unifacially retouched.

\section{Specimens made on flakes $(n=11)$}

Eleven specimens are made on flakes. Typically, a flake or flake fragment that is of appropriate shape and size is used in making these gunflints. These are shaped through minimal unifacial marginal retouch.

In her assessment of gunflint technology at Spanish colonial mission and presidio sites, Villalobos (2003) suggests that most gunflints recovered from archaeological contexts were not imported from Europe but instead produced locally. Based on comparative analysis between presidio and mission gunflints, she finds that natives made most of the gunflints exhibiting bifacial manufacturing techniques, and soldiers or Spanish residents manufactured gunflints from blades.

A small number of the gunflints appeared to retain different degrees of patina on their bodies. Suspecting that the pattern may be indicative of the reuse of "old" blanks, we exposed each specimens to short (2500 angstrom units) and long wave (3000-4000 angstrom units) ultra violet light using a Raytech Industries Inc., brand light. To our surprise, the analysis revealed that $14(50 \%)$ of the specimens were manufactured on "old" blanks that were re-flaked into gunflints well after the initial production of the blank. That is, these specimens were made on blanks that had been discarded long ago and had acquired sufficient patina so that their retouch exposed fresh surfaces that fluoresced in different colors. Typically, the older surfaces fluoresced a dark orange color, while the freshly flaked surfaces fluoresced a yellowish color. Ten $(36 \%)$ specimens showed no differential patina and flourescence suggesting that they were made relatively soon after the production of the blank.

In addition, the UV light scans revealed that four of the gunflints did not fluoresce the orange and yellow colors characteristic of cherts derived from Edwards Formation limestones. One of the four (Figure 6-5g) has a translucent honey color with lighter inclusions. It did not fluoresce under either the short of long wave. The honey color is reminiscent of French gunflint materials and while the lack of fluorescence supports a nonlocal origin for this material, the French connection remains only a hypothesis. The second specimen (Figure 6-5h), a dark gray to black piece also did not fluoresce under ultraviolet light. Its color is reminiscent of the English Brandon gunflints and its trapezoidal shape also argues for a blade blank that fits with the English manufacture technique. Again, at this point, we can say with certainty that the specimen is non-local but cannot be certain that is English in origin. The third gunflint (not shown) is made of a translucent light gray flint that is of high quality (i.e., it is well silicified). It did not fluoresce under either the short o long wave ultraviolet light waves. The final gunflint was made of chalcedony-like raw material similar to those present in large quantities in South Texas south of the Nueces River and continuing south of the Rio Grande.

\section{Other Tool Forms}

A variety of flaked lithic artifacts were recovered from the excavations at the Sales Museum. These flaked specimens were categorized into formal, minimally retouched and expedient lithic tools when it could be determined that the specimen was actually used. Use ware was determined using macroscopic and low power X15 magnification using a hand lens. Based on the type and location of use wear formal and minimally retouched tools were divided into functional categories (i.e., scrapers, knives, graver).

The distinction between formal, minimally retouched and expedient tools was made based on the amount of retouch on the surface of the tool. Formal tools include projectile points while minimally retouched specimens such as unifacial scrapers exhibit only a small degree of retouch in the preparation of their working edges. Expedient tool tend to be suitable pieces of debitage used in the performance 
of scraping and cutting tasks without the modification of the original flake edges. Retouched specimens on which use wear could not be identified were categorized into miscellaneous bifaces and unifaces, depending on the location of retouch. The condition of the tool was recorded and when present, retouching was noted. The tools were placed into six categories: projectile point, scrapers, graver, knives, indeterminate bifaces and indeterminate unifaces. Seventy-one complete and fragmented prehistoric tools, including projectile points, were collected during the project.

\section{Projectile Points}

A total of 22 projectile points and fragments were identified in the lithic tool sample (Table 6-2; Figure 6-6). Fifteen of the specimens are typed as Guerrero arrow points (Turner and Hester 1999:216). Of these, eight are complete points (Figure 6-6b-i), three are fragmentary (Figure $6-6 \mathrm{j}$ ) and the remaining four are performs (Figure 6-6a). The remaining seven specimens are too fragmentary to allow typological identification and one of the distal fragments may actually be part of a dart point or some other small bifacial artifact. One Guerrero point (Figure 6-6i) was manufactured from green glass.

Guerrero points are common at Spanish mission sites in Texas. They are triangular to lanceolate points with slight to moderately concave bases. Guerrero arrow point lengths range from 19.6 to $36.7 \mathrm{~mm}$, widths ranges from 12.2 to $16.7 \mathrm{~mm}$, and thicknesses from 2.5 to $4.3 \mathrm{~mm}$. The only complete Guerrero preform falls within these length and thickness ranges, but is slightly wider at $17.5 \mathrm{~mm}$.

\section{Scrapers}

Scrapers are hafted tools noted in the ethnographic record for preparing animal skins. Other microwear studies have shown scrapers were used on wood, bone, and antlers as well as skins (Siegel 1984). They were used in both directions (away and towards the user) and show use-wear on both dorsal and ventral surfaces. Generally, the angle of the edge is between 70 and 90 degrees, not acute enough for cutting (Andrefsky 1998). As with other unifaces, scrapers were likely used in a variety of ways on a variety of materials. The Sales Museum Collection of sixteen scrapers (Table 6-3) contains both "end scrapers" and "side scrapers". The eleven end scrapers show work on their distal ends. Five side scrapers were worked on the lateral margin. Three of the five are expedient side scrapers produced from secondary and tertiary flakes. The other two exhibit minimal retouching. All of the end scrapers $(n=11)$ are minimally retouched either just on the end or the end and margin of the flake blank. Unlike the indeterminate unifaces, most of the scrapers ( 81.25 percent) were produced from secondary flakes.

\section{Graver}

A single graver made from a secondary flake was recovered from the excavations (Table 6-3). It is a minimally retouched specimen. 
Table 6-2. Projectile Points from the Alamo Sales Museum Excavations

\begin{tabular}{|c|c|c|c|c|c|c|c|}
\hline Lot Number & $\begin{array}{c}\text { Max } \\
\text { Length }\end{array}$ & $\begin{array}{c}\text { Max } \\
\text { Width }\end{array}$ & $\begin{array}{c}\text { Max } \\
\text { Thickness }\end{array}$ & Completeness & Form & Failure & Comments \\
\hline $1991-273-320$ & 18.4 & 15.75 & 4.3 & proximal frag & Guerrero preform & indeterminate & only marginally chipped; slightly concave base \\
\hline $1991-237-300$ & 15.8 & 11.7 & 3.2 & proximal frag & Guerrero preform & manufacture & roundedly concave base; -not angled- \\
\hline 1991-083-023 & 21 & 16 & 4.1 & proximal frag & Guerrero & use & straight based \\
\hline $1991-273-322$ & 29.3 & 17.5 & 4.3 & complete & Guerrero preform & & $\begin{array}{l}\text { marginally retouched curved flake; slightly } \\
\text { concave base }\end{array}$ \\
\hline 1991-273-318 & 18.5 & 14.6 & 4.3 & proximal frag & Guerrero preform & manufacture & only marginally chipped; concave based \\
\hline 1991-237-302 & 19.2 & 13.4 & 2.5 & complete & Guerrero & & concave base, angled \\
\hline $1991-65-18$ & 16.9 & 12.5 & 2.9 & complete & Guerrero & & $\begin{array}{l}\text { only marginally flaked but looks finished; } \\
\text { concave based }\end{array}$ \\
\hline $1991-273-315$ & 28.9 & 12.7 & 3 & complete & Guerrero & & sharply concave base \\
\hline $1991-273-321$ & & & 3.2 & medial frag & Untypable AP & indeterminate & untypable arrow point frag \\
\hline 1991-171-005 & & & 2.1 & distal frag & Untypable AP & manufacture & untypable arrow point frag \\
\hline 1991-083-025 & & & 3.3 & edge frag & Untypable AP & manufacture & untypable arrow point frag \\
\hline 1991-83-024 & & & 4.2 & distal frag & Untypable AP & manufacture & untypable arrow point frag \\
\hline 1991-105-22 & & & 3.6 & medial frag & Untypable AP & manufacture & untypable arrow point frag \\
\hline $1991-222-020$ & & & 4.7 & distal frag & Untypable AP or DP & indeterminate & $\begin{array}{l}\text { heat spalled biface tip; possible dart or arrow } \\
\text { point frag }\end{array}$ \\
\hline 1991-273-319 & & & 2.6 & edge frag & Untypable AP & indeterminate & untypable arrow point edge frag \\
\hline $1991-237-299$ & & & 2.9 & medial frag & Guerrero & indeterminate & \\
\hline 1991-65-017 & 36.7 & 12.2 & 3.1 & complete & Guerrero & & straight base; small piece of tip missing \\
\hline 1991-65-020 & 24.7 & 13.2 & 3.6 & complete & Guerrero & & straight base; \\
\hline 1991-273-317 & 29.6 & 14.6 & 3.7 & complete & Guerrero & & small section of tip missing; \\
\hline 1991-65-019 & 21.1 & 15.9 & 3.9 & complete & Guerrero & & made of green glass; one ear missing; \\
\hline 1991-273-316 & 21.2 & 9.4 & 2.9 & proximal frag & Guerrero & indeterminate & concave based; \\
\hline $1991-273-314$ & 28.1 & 16.7 & 4.3 & complete & Guerrero & & marginally retouched but appears finished; \\
\hline
\end{tabular}

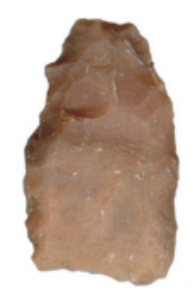

a
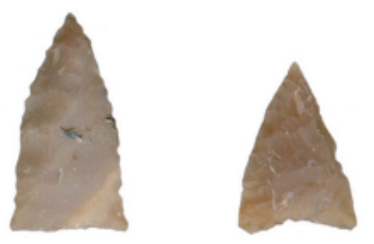

g

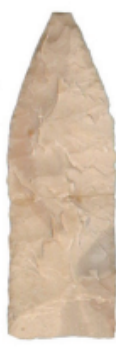

b

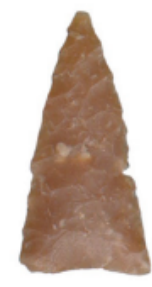

C
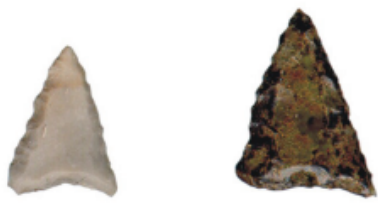

h

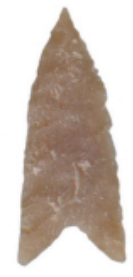

d

$$
\text { i }
$$

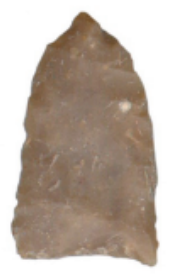

e

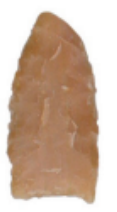

j

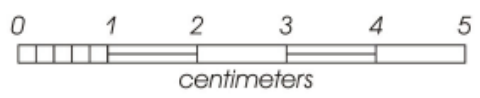

Figure 6-6. Guerrero arrow points: (a) perform; (b-i) complete points; (j) proximal fragment. Note specimen (i) made of glass.

\section{Knives}

Two knives were identified in the collection (Table 6-3). Both are complete specimens with minimal retouching. One knife, made on a tertiary flake, has two worked edges. The other, made on a secondary flake, has only one worked edge.

\section{Miscellaneous Bifaces}

Ten complete and fragmented bifaces were identified representing all stages of reduction (Table 6-3). The sample includes three complete, but unfinished bifaces -- two large, early stage bifaces and one smaller, late stage biface. Three of the remaining seven fragments are early, middle, and late-reduction stage biface fragments. The single late reduction stage fragment resembles the base of a triangular dart. 
Table 6-3. Lithic Tools and Miscellaneous Bifaces and Unifaces from the Alamo Sales Museum Excavations

\begin{tabular}{|c|c|c|c|}
\hline Lot Number & Tool Form & Blank Type & Condition \\
\hline & Scrapers & & \\
\hline 1991-034-021 & expedient side scraper & tertiary flake & complete \\
\hline 1991-237-236 & expedient side scraper & secondary flake & complete \\
\hline $1991-273-216$ & expedient side scraper & tertiary flake & prox frag \\
\hline 1991-190-001 & min. retouched side scraper & secondary flake & complete \\
\hline 1991-273-220 & min. retouched side scraper & secondary flake & complete \\
\hline $1991-237-286$ & min. retouched end scraper & secondary flake & complete \\
\hline 1991-237-286 & min. retouched end scraper & secondary flake & complete \\
\hline 1991-283-047 & min. retouched end scraper & secondary flake & complete \\
\hline $1991-273-214$ & min. retouched end scraper & secondary flake & complete \\
\hline $1991-237-280$ & min. retouched end scraper & secondary flake & complete \\
\hline 1991-125-019 & min. retouched end scraper & secondary flake & complete \\
\hline $1991-237-282$ & min. retouched end scraper & secondary flake & complete \\
\hline 1991-043-006 & min. retouched end scraper & secondary flake & complete \\
\hline 1991-238-099 & min. retouched end scraper & secondary flake & complete \\
\hline 1991-273-266 & min. retouched end scraper & secondary flake & complete \\
\hline \multirow[t]{2}{*}{ 1991-020-001 } & min. retouched end scraper & tertiary flake & distal frag \\
\hline & Graver & & \\
\hline \multirow[t]{2}{*}{$1991-273-263$} & min. retouched graver & secondary flake & complete \\
\hline & Knives & & \\
\hline $1991-237-285$ & min. retouched knife & tertiary flake & complete \\
\hline \multirow[t]{2}{*}{ 1991-267-006 } & min. retouched knife & tertiary flake & complete \\
\hline & Miscellaneous Bi & & \\
\hline 1991-204-007 & biface & indeterminate & prox frag \\
\hline 1991-190-002 & biface & indeterminate & complete \\
\hline 1991-214-001 & biface & indeterminate & medial frag \\
\hline 1991-237-199 & biface & indeterminate & medial frag \\
\hline 1991-222-16 & biface & indeterminate & edge frag \\
\hline 1991-273-219 & biface & indeterminate & medial frag \\
\hline 1991-259-012 & biface & indeterminate & prox frag \\
\hline 1991-020-008 & biface & secondary flake & complete \\
\hline 1991-237-109 & biface & indeterminate & prox frag \\
\hline \multirow[t]{2}{*}{ 1991-033-004 } & biface & secondary flake & complete \\
\hline & Miscellaneous Un & & \\
\hline 1991-237-115 & misc., uniface edge & secondary flake & medial frag \\
\hline 1991-237-111 & misc., uniface edge & secondary flake & edge frag \\
\hline 1991-171-002 & misc., uniface edge & tertiary flake & edge frag \\
\hline 1991-273-186 & misc., uniface edge & tertiary flake & edge frag \\
\hline 1991-273-190 & misc., uniface edge & tertiary flake & edge frag \\
\hline 1991-273-185 & misc., uniface edge & tertiary flake & edge frag \\
\hline 1991-273-191 & misc., uniface edge & tertiary flake & edge frag \\
\hline 1991-237-130 & misc., uniface edge & tertiary flake & edge frag \\
\hline 1991-083-016 & miscellaneous uniface & tertiary flake & distal frag \\
\hline $1991-237-273$ & miscellaneous uniface & tertiary flake & distal frag \\
\hline $1991-273-268$ & miscellaneous uniface & secondary flake & complete \\
\hline 1991-273-218 & miscellaneous uniface & secondary flake & prox frag \\
\hline 1991-273-211 & miscellaneous uniface & tertiary flake & complete \\
\hline $1991-273-267$ & miscellaneous uniface & secondary flake & longit frag \\
\hline 1991-217-25 & miscellaneous uniface & secondary flake & complete \\
\hline 1991-029-039 & miscellaneous uniface & secondary flake & distal frag \\
\hline $1991-273-215$ & miscellaneous uniface & tertiary flake & complete \\
\hline 1991-273-182 & miscellaneous uniface & tertiary flake & distal frag \\
\hline $1991-237-237$ & miscellaneous uniface & secondary flake & distal frag \\
\hline $1991-237-288$ & miscellaneous uniface & tertiary flake & prox frag \\
\hline
\end{tabular}




\section{Miscellaneous Unifaces}

Most of the miscellaneous unifaces recovered are edge modified flakes exhibiting retouch on one face. The twenty unifacial flake tools in this collection are all made on secondary or tertiary flakes (Table 6-3). Most exhibit a single retouched edge but some have two and three modified edges. Eight of these are too fragmented to observe the number of retouched edges. Sixty percent of the miscellaneous unifaces from the collection were produced from tertiary flakes. The remaining forty percent were from secondary flakes.

\section{Lithic Manufacture Debris}

In addition to 7 cores, 522 pieces of debitage were collected during the project. Because the methods of collection varied between proveniences, these samples are highly biases and therefore will not be discussed in detail. 



\section{Chapter 7: Summary and Conclusions}

\section{Steve A. Tomka and Anne A. Fox}

The Center for Archaeological Research of The University of Texas at San Antonio was contracted by The Daughters of the Republic of Texas to carry out the analysis and preparation for curation and to curate the artifacts derived from archaeological investigations conducted prior to renovations to the Alamo Sales Museum. The archaeological investigations were conducted by Lone Star Archaeological Services, under the direction of Alton K. Briggs. While several reports were prepared and submitted by Briggs, they were found unacceptable by the Texas Historical Commission and the Center was hired to conduct the analysis of the artifacts and prepare a technical report that would meet standards.

Archaeological work at the Museum consisted of five principal tasks: 1) pre-asbestos abatement testing under the building; 2) abatement monitoring; 3) mechanical testing of the project area; 4) pre-basement excavation impact area testing; and finally, 5) monitoring of the excavation of the basement and elevator tunnel and recovery of selected artifacts. The completion of these tasks stretched over nearly two years beginning in July 1991 and ending in April 1993. The different tasks were completed in three phases. During the first phase of work, the goal of the archaeological investigations was to determine whether archaeological materials were even present under the Museum, and, if they were there, would they be harmed in the process of asbestos abatement prior to construction. To address this concern, pre-asbestos abatement testing was performed under the structure. During the second phase of work, archaeologists were involved in excavations of an access pit for the asbestos abatement teams under the north wall of the Museum. This work was to recover a representative sample of cultural materials and also document the stratigraphy in this portion of the project area. As part of the third phase of investigations, large scale mechanical testing of the area adjacent to and under the museum was undertaken. The goal of these investigations was to document what was the extent of intact cultural deposits under the Museum and what was their research potential.

One of the key concerns on the project was the extent to which the construction of the Sales Museum may have disturbed the cultural material-bearing deposits. In addition, it was also likely that historic activities on site may also have impacted archaeological deposits. To address this later concern, Briggs investigated the locations of acequia ditches that crossed through or passed near the location of the Museum building. Using Everett's 1848 map, he concluded that specific areas under the structure had been disturbed by the construction of a diversion ditch of the acequia by the U.S. Army in 1848 . The reconstructed route of the diversion ditch had specific bearing on what he expected to find in the excavation units positioned around the perimeter of the building.

Because of concerns about the accuracy of the Everett map, CAR staff compared the location of the diversion ditch with one pictured in a 1849 U.S. Army map of the same feature. This map located the ditch somewhat east of the Everett location suggesting that most of the impacts from this acequia diversion should be under the southeast corner of the Museum building rather than along the west wall of the structure. This repositioning of the diversion ditch, significantly affected our interpretations of the profiles of the units excavated during the project and lead to different interpretations compared to those made by Briggs in the two draft reports submitted to the THC. These differences are noted below in the discussions of the appropriate excavation units.

As part of the pre-abatement investigations, 13 50-x-50 $\mathrm{cm}$ test units were excavated under the building and two locations were surface collected. The excavations sampled the upper 15-30 $\mathrm{cm}$ of deposits that were to be impacted by the asbestos abatement work. The area beneath the museum did not yield information of value to the structural history of the museum area. The mix of large numbers of cut and wire nails and ceramics clearly indicates heavy mixing at least in the deposits sampled during the pre-abatement excavations.

To allow access to the area under the building for the asbestos abatement, crews mechanically excavated the Access Pit adjacent to the north wall of the Sales Museum. The size of the initial pit was approximately $5.5(\mathrm{E}-\mathrm{W}) \mathrm{x} 4(\mathrm{~N}-\mathrm{S})$ feet and it was subsequently enlarged to a $6(\mathrm{E}-\mathrm{W}) \times 6.7(\mathrm{~N}-\mathrm{S})$ foot unit. Two additional units were added to it at a later date, Test Pit L and Test Pit North of L. Finally, a passageway was also excavated adjoining Test Pit $\mathrm{L}$ to allow access under the building.

The northwest portion of the access pit revealed a feature consisting of a line of limestone blocks placed on edge surrounding a flat compact caliche floor, the likely floor of a structure. The pit dug for the construction of one of the concrete piers was also documented in this area. The analysis of the artifacts recovered was based on analysis units defined by CAR staff. The results indicate that while the upper two 
analysis units are disturbed and contain a mix of $19^{\text {th }}$ century and colonial artifacts, the bottom analysis unit is relatively intact and contains primarily colonial materials.

According to Briggs, the excavation of Trench 1 revealed several features, including three prepared Spanish Colonial floors and evidence of the U.S. Army acequia diversion ditch. Lacking detailed excavation level notes, there are no means to verify Briggs' reconstruction of the floors. However, the inspection of the profile and profile descriptions suggest that what Briggs identifies as evidence of the diversion ditch is actually a series of intersecting utilities installation ditches near the west wall of the Museum. Supporting this conclusion is the U.S. Army map which indicates that the ditch should be further east of the location suggested by the Everett map. The analysis of the stratigraphy and artifact assemblage derived from Trench 1 showed that while colonial period artifacts tend to be more common in the deeper strata, these proveniences are significantly disturbed.

Trench 2 was positioned to the west-northwest of the Museum and its east-west extension is located directly north of the building. Briggs states that two features, consisting of stone alignments, were exposed in the Trench 2 profile within the along the western half of the trench. He suggests that these features are wall-like and foundation-like and at least the deepest of them may predate the establishment of the Alamo Mission. According to Briggs, the east-west trench extension also exposed a feature, a compact layer of clay and river gravels that is roughly six inches thick. He interprets this layer as representing a flooring episode dating to the U.S. Army occupation of the site. The artifact analysis suggests that the deeper deposits (i.e., Levels 3 and 4) in the western half of Trench 2 may be relatively intact Colonial strata. In contrast, the deposits in the east-west extension of Trench 2 appear to be extremely mixed.

Trench 3 was excavated on the east side of the museum. Briggs comments that the bulk of the deposits in this area have been heavily disturbed by the construction of the Museum and the acequia that is located just east of the area investigated. The analysis of the artifacts from this trench supports the conclusion that the deposits are heavily mixed.

The northwest test unit measured 2-x-2 meters and was positioned north of the Sales Museum. It revealed one feature (Feature 5a) that consisted of a cluster of $19^{\text {th }}$ century materials covering an area roughly $35-\mathrm{x}-43 \mathrm{~cm}$ in size at a depth of $35.5 \mathrm{~cm}$ below surface. The analysis of the materials recovered indicates that while colonial materials tend to cluster in the deeper strata, $19^{\text {th }}$ century materials are common in those same strata.
The southeast test unit, is an L-shaped 2-x-3 meter unit adjoining the southeast corner of the Museum building. Profile descriptions provided by Briggs indicate that a trench (Feature 1) measuring ca. $30 \mathrm{~cm}$ in width had been cut from west-northwest to east-southeast in Level 8, at the base of the unit. While Briggs does not comment on the trench in the preliminary reports, the 1849 U.S. Army map suggests that this trench may be the bottom of the acequia diversion ditch that was constructed by the Army to bring water into the wagon yard. Based on the fact that $19^{\text {th }}$ century materials well outnumber Colonial specimens even in Levels 5 and 6 of the unit, it is clear that the deposits in this area are heavily disturbed.

The overall analysis of the materials recovered during the excavations indicates that a broad range of Colonial and English ceramic wares are present. One interesting aspect of the analysis derived from the study of the gunflints and arrow points. Twenty-two projectile points were recovered with at least fifteen of the more complete specimens being Guerrero arrow points. Among these 15 was a small triangular Guerrero point made of green glass. Twenty-eight gunflints were also identified in the collection of chipped lithic artifacts. The analysis of these specimens under short and long wave ultraviolet light indicated that half of the collection consists of pieces made on "old" blanks. These old banks tended to be previously discarded flakes and bifacial artifacts that were recycled as blanks for gunflint manufacture. The ultraviolet light analysis also revealed that four of the specimens do not fluoresce the typical orange to yellow color characteristic of flints derived from limestone members of the Edwards Formation. These four specimens are made of raw materials not derived from the Edwards Plateau. One of these four may be an English gunflint and another may be a French gunflint. The third specimen appears to be visually similar to Edwards cherts, and was originally assumed to be a local material. The final specimen is made of a chalcedony-like material probably obtained in South Texas, south of the Nueces River.

Finally, several previously unrecognized findings emerged from the work conducted with the Alamo Sales Museum. One of these is the recognition of the changes in the location of the acequia, first when the U.S. Army diverted a section into the area east of the convento, then later when the acequia was moved slightly to the east of its original channel during the 1936-37 restoration and construction of the Alamo Sales Museum.

Another is the recovery of a comparatively large sample of Puebla Polychrome majolica, a type that has been found only in the earliest contexts in San Antonio. Its presence in this part of the Alamo site reinforces previous suspicions that the 
first, temporary buildings of the mission were located in this area while the convento was under construction.
No artifacts were found that would have resulted from the Battle of the Alamo. 



\section{References Cited}

Adams, R.E.W., and T.R. Hester

1973 Letter to Dr. Fred Wendorf, Chairman, Texas Antiquities Committee, concerning completion of excavations at Mission San Antonio de Valero, November 26.

Albert, A.H.

1969 Record of American Uniform and Historical Buttons with Supplement. Boyerstown Publishing Company, Boyerstown, Pennsylvania.

Almaráz, F.D.

1971 Tragic Cavalier: Governor Manuel Salcedo of Texas, 1808-1813. University of Texas Press, Austin.

Anderson, G.C.

2005 The Conquest of Texas: Ethnic Cleansing in the Promised Land, 1820-1875. University of Oklahoma Press, Norman

Andrefsky, W.Jr.

1998 Lithics: Macroscopic Approaches to Analysis. Cambridge University Press, Cambridge.

Barnes, M.F., and R.V. May

1972 Mexican Majolica in Northern New Spain. Occasional Paper, Number 2. Pacific Coast Archaeological Society, Costa Mesa, California.

Barr, L.

1990 Texans in Revolt: The Battle for San Antonio, 1835. University of Texas Press, Austin.

BCDR (Bexar County Deed Records)

http://www.countyclerk.bexar.landata.com/. Accessed June 1, 2008.

Bowden, J.J.

1986 The Exodus of Federal Forces from Texas 1861. Eakin Press, Austin.

Briggs, A.K.

1992 Archeological Testing and Trenching in the Proposed Alamo Sales Museum Expansion Project, at the Alamo Shrine and Museum in San Antonio, Bexar County, Texas. Lone Star Archeological Services. Austin.

1993 Archeological Testing, Trenching and Excavations for the Alamo Sales Museum Expansion Project at the Alamo Shrine and Museum (Mission San Antonio de Valero), San Antonio, Bexar County, Texas. Lone Star Archeological Services. Austin.

1998 Archeological Investigations at the Alamo Misión San Antonio de Valero San Antonio, Bexar County, Texas. Lone Star Archeological Services. Comfort.

Castañeda, C.E.

1938 Our Catholic Heritage in Texas, 1519-1936. Volume II. Von Boeckmann-Jones, Austin. 
Charlton, T.H., and R.R. Katz.

1979 Tonalá Bruñida Ware. Archaeology 32(1):45-53.

Chipman, D.E.

1992 Spanish Texas, 1519-1821. University of Texas Press, Austin.

Cox, I.W.

1994 The History and Development of Alamo Plaza. In A Historical Overview of Alamo Plaza and Camposanto, ed., by R.J. Hard, pp. 1-3. Special Report, No. 20. Center for Archaeological Research, The University of Texas at San Antonio.

2005 The Spanish Acequias of San Antonio. Maverick Publishing Company.

Darrow, C.D.

1884 Recollection of the Twiggs Surrender. In Battles and Leaders of the Civil War: Being For the Most Part Contributions by Union and Confederate Officers: Based Upon "The Century War Series," edited by R. U. Johnson and C. C. Buel, pp. 33-39. Century, New York.

Daughters of the Republic of Texas (DRT) Library

1994 DRT/Alamo Complex Chronology. Manuscript on file, Daughters of the Republic of Texas Library, The Alamo, San Antonio.

Deagan, K.

1987 Artifacts of the Spanish Colonies of Florida and the Caribbean 1500-1800. Volume 1:Caramics, Glassware, and Beads. Smithsonian Institution Press, Washington, D.C.

de la Peña, J.E.

1975 With Santa Anna in Texas: A Personal Narrative of the Revolution. Translated and edited by C. Perry. Texas A\&M University Press, College Station.

de la Teja, J.F.

1995 San Antonio de Bexar: A Community of New Spain's Northern Frontier. University of New Mexico Press, Albuquerque.

Dover Publications, Inc.

1969 Montgomery Ward \& Co. Catalog No. 57. Spring \& Summer 1895, Reprint of the original edition, New York.

Eaton, J.D.

1980 Excavation at the Alamo Shrine (Mission San Antonio de Valero). Special Report, No. 10. Center for Archaeological Research, The University of Texas at San Antonio.

Faulk, O.B., and J.A. Stout (editors)

1973 The Mexican War: Changing Interpretations. Swallow, Chicago.

Fehrenbach, T.R.

1968 Lone Star, A History of Texas and the Texans. McMillian Company, Toronto.

Filisola, V.

1985[1848] Memoirs for the History of the War in Texas. Vol. I, translated by W. Woosley. Eakin Press, Austin. 
Fox, A.A.

1976 Archaeological Investigations at Fort Griffin State Historic Park, Shackelford County, Texas. Archaeological Survey Report, Number 23. Center for Archaeological Research, The University of Texas at San Antonio.

1992 Archaeological Investigations in Alamo Plaza, San Antonio, Bexar County, Texas, 1988 and 1989. Archaeological Survey Report, No. 205. Center for Archaeological Research, The University of Texas at San Antonio.

Fox, A.A., F.A. Bass, and T.R. Hester

1976 The Archaeology and History of Alamo Plaza. Archaeological Survey Report, No. 16. Center for Archaeological Research, The University of Texas at San Antonio.

Fox, A.A., M. Renner, and R.J. Hard (editors)

1997 Archaeology at the Alamodome: Investigations of a San Antonio Neighborhood in Transition, Volume I: Historical, Architectural and Oral History Research. Archaeological Survey Report, No. 238, Center for Archaeological Research, The University of Texas at San Antonio.

Garrett, J.K.

1968[1939] Green Flag Over Texas: A Story of the Last Years of Spain in Texas. Pemberton Press, Austin.

Gilmore, K.

1974 Mission Rosario, Archeological Investigations 1973. Texas Parks \& Wildlife Department, Historic Sites and Restoration Branch. Archeological Report 14, Part 1.

Glassman, D.M.

1994 Description and Interpretation of Skeletal Remains from Burials on Alamo Plaza, San Antonio, Texas. Report on file, Department of Anthropology, Southwest Texas State University, San Marcos.

Goggin, J.M.

1968 Spanish Majolica in the New World, Types of the Sixteenth to Eighteenth Centuries. Department of Anthropology, Yale Publications in Anthropology, Number 72. Yale University.

Greer, G.H.

1981 American Stonewares. Schiffer Publishing Limited, Pennsylvania.

Greer, G.H. and H. Black

1971 The Meyer Family: Master Potters of Texas. Trinity University Press, San Antonio.

Greer, J.W.

1967 A Description of the Stratigraphy, Features, and Artifacts from an Archeological Excavation at the Alamo. Archeological Program, Report 3. State Building Commission, Austin.

Guderjan, T.H.

2003 Excavations at the Alamo (41BX6) 1995 “Alamo Well” Project. Draft submitted to the Texas Antiquities Commission.

Habig, M.A.

1968 The Alamo Chain of Missions: A History of San Antonio’s Five Old Missions. Franciscan Herald Press, Chicago. 
Handbook of Texas Online, s.v.

2008 http:/www.tshaonline.org/handbook/online/articles/SS/qfs1.html (accessed November 18, 2008).

Hardin, S. L.

1994 Texian Iliad: A Military History of the Texas Revolution, 1835-1836. University of Texas Press, Austin.

Hughes, G.B.

1967 Victorian Pottery and Porcelain. Spring Books, London.

Ivey, J.E., M.B. Thurber, and S. Escobedo

1997 Of Various Magnificence, The Architectural History of the San Antonio Missions in the Colonial Period and the Nineteenth Century. Volume One of An Architectural and Administrative History of the San Antonio Missions in Two Volumes. National Park Service, Southwest Regional Office, Southwestern Cultural Resources Center, Professional Papers No 11, Santa Fe. Draft on file at Center for Archaeological Research.

Ivey, J.E., and A.A. Fox

1981 Archaeological Survey and Testing at Rancho de Las Cabras, Wilson County, Texas. Archaeological survey Report 104. Center for Archaeological Research, The University of Texas at San Antonio,

1997 Archaeological and Historical Investigations at the Alamo North Wall, San Antonio, Bexar County, Texas. Archaeological Survey Report, Number 224. Center for Archaeological Research, The University of Texas at San Antonio.

1999 Archeological Investigations at Mission Concepción an Mission Parkway. Archaeological Survey Report 114.Center for Archaeological Research, The University of Texas at San Antonio.

James, V.L.

1938 Frontier and Pioneer Recollections of Early Days in San Antonio and West Texas. Self published, San Antonio.

Jenkins, J.H.

1973 Papers of the Texas Revolution. 10 Volumes. Presidial Press, Austin.

John, E.A.H.

1975 Storms Brewed in Other Men's Worlds: Confrontations of Indians, Spanish and French in the Southwest, $1540-1795$. Texas A\&M University Press, College Station.

Lehner, L.

1898 Lehner's Encyclopedia of U.S. Marks on Pottery, Porcelain, and Clay. Collector Books Schroeder Publishing Co., Inc. Paducah, Kentucky.

Lister, F.C., and R.H. Lister.

1974 Majolica in Colonial Spanish America. Historical Archaeology 8:17-52.

Meissner, B.A.

1996 The Alamo Restoration and Conservation Project: Excavations at the South Transept. Archaeological Survey Report, No. 245. Center for Archaeological Research, The University of Texas at San Antonio. 
Menchaca, A.

1937 Memoirs. Yanaguana Society Publications, Vol. 2, Yanaguana Society, San Antonio.

Miller, G.L.

n.d. Some Notes on blue Edgeware. Unpublished manuscript on file, Center for Archaeological Research.

Miller, J.J., and L.M. Stone

1970 Eighteenth Century Ceramics from Fort Michilimackinac: A Study in Historical Archaeology. Smithsonian Institution Press, Washington, D.C.

Mounger, M.A.

1959 Mission Espíritu Santo of Coastal Texas: An Example of Historic Site Archeology. Masters Thesis, The University of Texas, Austin.

Nelson, G.S.

1998 The Alamo: An Illustrated History. Aldine Press, Uvalde.

Newcomb, R.,Jr.

1947 Ceramic Whitewares. Pitman, New York.

Nickels, D.L.

1999 An Archaeological Assessment of the Drainage Improvement Area on the Northeast Side of Alamo Hall, and Home of Former Mayor Wilhelm Thielepape (41BX507), San Antonio, Texas. Archaeological Survey Report, No. 244. Center for Archaeological Research, The University of Texas at San Antonio.

Paredes, de, M.S.

1727 Visita de las Misiones del Rio Grande del Norte por Fr. Miguel Sevillano de Paredes en 15 de Octubre 1727. Archivo General de Mexico: Historia. Vol. 29, pp. 35-68. Typescript on file in Barker Texas History Center. Austin.

Paulus, M.

1939 Fifteen Years in Old San Antonio, 1850-1865. Unpublished Master's thesis on file, Center for Archaeological Research, The University of Texas at San Antonio.

Ramsday, J.

1976 American Potters and Pottery. Ars Ceramica, Ltd., Ann Arbor, Michigan.

Robacker, E.F., and A.F. Robacker 1978 Spatterware and Sponge, Hardy Perennials of Ceramics. A.S. Barnes and Company, New Jersey.

San Antonio Daily Express, February 3, 1896

San Antonio Evening News, October 15, 1938

San Antonio Light, January 29, 1905.

Schuetz, M.K.

1966 Historic Background of the Mission San Antonio de Valero. Archeological Program, Report 1. State Building Commission, Austin. 
1969 The History and Archeology of Mission San Juan Capistrano, San Antonio, Texas. Volume II. Archeology Program, Report Number 11. State Building Commission, Austin.

1973 Archeological Investigations at Mission San Antonio de Valero, the Second Patio. Manuscript on file. Office of the State Archeologist, Texas Historical Commission, Austin.

Seifert, D.J.

1977 Archaeological Majolicas of the Rural Teotihuacán Valley, Mexico. Ph.D. Dissertation, The University of Iowa.

Shepard, A.O.

1968 Ceramics for the Archaeologist. Carnegie Institution of Washington, D. C.

Siegel, P.E.

1984 Functional Variability Within an Assemblage of Endscrapers. Lithic Technology 13(2):35-51.

Simmons, M., and F. Turley

1980 Southwestern Colonial Ironwork. Museum of New Mexico Press, Santa Fe.

Sorrow, W.M.

1972 Archeological Salvage Excavations at the Alamo (Mission San Antonio de Valero) 1970. Report No. 4. Texas Archeological Salvage Project Research, Austin.

Steinfeldt, C.

1978 San Antonio Was: Seen Through a Magic Lantern. Views from the Slide Collection of Albert Steves, Sr. San Antonio Museum Association, San Antonio.

Story, A.B.

1938 The Alamo from Its Founding to 1937. Master's thesis, The University of Texas at Austin. Copy on file, Daughters of the Republic of Texas Library, San Antonio.

Suhm, D.A., and E.B. Jelks

1962 Handbook of Texas Archeology: Type Descriptions. Texas Archeological Society Special Publication, Number One, Texas Memorial Museum Bulletin Number Four, Austin.

Tennis, C.L.

2002 Nuestra Señora del Refugio (41RF1), Refugio County, Texas. Volume 1 Archaeological Investigations. Archaeological survey Report 315. Center for Archaeological Research, The University of Texas at San Antonio.

Turner, S.E. and T.R. Hester

1999 A Field Guide to Stone Artifacts of Texas Indians. Gulf Publishing. Rowan \& Littlefield Publishers, Inc., New York.

Villalobos,

2003 A Study of Gunflints from Spanish Colonial Sites. Unpublished Master's Thesis. Department of Anthropology, The University of Texas at San Antonio. 
Williams, A.

1931 A Critical Study of the Siege of the Alamo and the personnel of its defenders. Unpublished Ph.D. dissertation. The University of Texas at Austin.

Winders, R.B.

2004 Sacrificed at the Alamo: Tragedy and Triumph in the Texas Revolution. Texas A\&M University Press, College Station.

Witthoft, J.

1966 A History of Gunflints. Pennsylvania Archaeologist 36:8-43.

Yakubik, J.K.

1990 Ceramic Use in Late Eighteenth Century and Early Nineteenth Century Southeastern Louisiana. Ph.D. Dissertation, Tulane University.

Young, K.R.

1991 Notes and Related Correspondence covering the United States Army Quarter Master's Occupation of the Alamo1846-1854. Manuscript on file, Center for Archaeological Research, The University of Texas at San Antonio. 